Check for updates

Cite this: RSC Adv., 2017, 7, 27299

\title{
Green corrosion inhibitors for aluminium and its alloys: a review $\uparrow$
}

\author{
Klodian Xhanari, (D) ab Matjaž Finšgar, (D) *a Maša Knez Hrnčič, ${ }^{a}$ Uroš Maver, (DD c \\ Željko Knez ${ }^{a}$ and Bujar Seitib
}

This review summarises the research work published in the last two decades on the use of natural compounds as corrosion inhibitors for aluminium and aluminium alloys in different solutions. Herein, plant extracts, gums, drugs, and oils have been considered as green corrosion inhibitors. The advantages and disadvantages of the methods used to obtain green corrosion inhibitors are presented. Additionally, the inhibition effectiveness of these corrosion inhibitors, including the techniques used to evaluate them and the respective inhibition mechanisms, are discussed. Finally, a critical evaluation is presented together with the outlook as regards possible future improvements.

Received 6th April 2017

Accepted 10th May 2017

DOI: $10.1039 / c 7 r a 03944 a$

rsc.li/rsc-advances

review article have been tested as corrosion inhibitors for

\section{Introduction}

Corrosion-related costs represent up to a few percent of the gross domestic product (GDP) of the most developed countries in the world, ${ }^{1}$ which can sometimes be close to what is spent on, for example, public education or healthcare. Due to this reason, corrosion and its related phenomena have always been of great interest to the scientific community.

Aluminium is found in its ionic form in most kinds of animal and plant tissues and in natural waters everywhere. ${ }^{2}$ It is the third most prevalent element and the most abundant metal in the earth's crust, representing approximately $8 \%$ of total mineral components. ${ }^{3}$ Dietary aluminium is ubiquitous but exists in such small quantities that it is not a significant source of concern in humans with normal elimination capacity. ${ }^{4}$ The most important feature of aluminium is its high strength to weight ratio. Its high electrical and thermal conductivity, in addition to its relatively low price, make aluminium very attractive in various applications. ${ }^{5}$ The mechanical properties of pure aluminium can be significantly improved by adding different elements forming alloys. Several alloy series have been developed. The type and amount of the elements added influence not only the mechanical properties, but also the corrosion resistance of aluminium alloys. The higher the purity of the alloy, the less susceptible it is to pitting corrosion. Therefore, it is of great importance to know the chemical composition of the aluminium alloy. The natural products summarised in this

${ }^{a}$ University of Maribor, Faculty of Chemistry and Chemical Engineering, Smetanova ulica 17, 2000 Maribor, Slovenia. E-mail: matjaz.finsgar@um.si; Tel: +386 22294447 ${ }^{b}$ University of Tirana, Faculty of Natural Sciences, Boulevard "Zogu I", 1001 Tirana, Albania

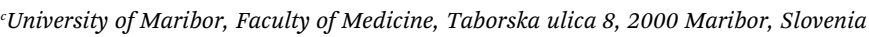
$\dagger$ Electronic supplementary information (ESI) available. See DOI: 10.1039/c7ra03944a various types of aluminium alloys. However, in the majority of the cases the authors do not designate the alloy type. Moreover, in some cases the chemical composition of the same alloy type, obtained by different providers, it is not the same. Therefore, in Table S1 (in the ESI $\dagger$ ) we present the chemical composition and respective designation (as reported by the authors) for the tested aluminium alloys.

In terms of corrosion, aluminium by itself is not resistant, however if an oxide layer is formed on the surface, it becomes highly resistant to corrosive attack in various media. However, when exposed to acidic, alkaline, and chloride-containing media, the oxide layer is damaged, exposing the aluminium materials to the attack of the corrosive environment. ${ }^{6,7}$

Different methods can be employed to protect aluminium and its alloys. For closed systems or sometimes even under flowing conditions, it is convenient to employ corrosion inhibitors. A corrosion inhibitor is a chemical compound that is added to the corrosive medium in very small amounts (usually up to $1 \mathrm{wt} \%)$. These compounds then adsorb on the metallic surface and mitigate corrosion. The performance of corrosion inhibitors is usually evaluated from the calculation of the inhibition effectiveness, i.e. a percentage calculation of the corrosion rate relative to the medium without a corrosion inhibitor. Herein, the corrosion rate is usually related to weight loss (how much mass of the sample is lost after the corrosion tests) and hydrogen evolution (the volume of released hydrogen is measured). These two techniques were the most frequently employed methods to evaluate corrosion inhibition effectiveness.

In order to increase the performance of a corrosion inhibitor, a mixture of surfactant(s), solvent(s), and intensifier(s) is usually blended. This mixture is then called a corrosion inhibitor formulation. ${ }^{8}$ A corrosion inhibitor is usually effective for 
a certain metallic material in a particular environment and even minor change can cause it to become ineffective. Even though some models (especially quantum chemical calculations) are lately being developed to forecast corrosion inhibition effectiveness, for the moment, empirical tests are still the most reliable methods in corrosion inhibition effectiveness research. This is due to the fact that the inhibition mechanisms of these compounds on metallic surfaces are frequently not well known.

Organic compounds are frequently used as corrosion inhibitors. However, the toxicity of organic compounds combined with their low cost and availability, have made natural products an excellent alternative as possible corrosion inhibitors. Furthermore, the care for the environment by using sustainable resources abundant in nature is already of paramount importance and will have an increasing impact on society and the well-being of people. As a result, natural products will become even more important in the near future. As shown herein, natural compounds have already been extensively employed as useful substitutes for synthetic materials in different corrosion inhibition applications. The authors reported herein designate the employed inhibitors as green, ecofriendly or environmentally acceptable. Several groups of natural compounds have been investigated as possible corrosion inhibitors for aluminium materials. Fig. 1 shows the distribution of the research work published in the last two decades on these groups of products, which are presented in this review article. The majority of these studies have been focused on plant extracts. The main constituents of the plant extracts have been reported to be a wide variety of organic compounds, including polyphenols, terpenes, carboxylic acids and alkaloids. Therefore, most of these compounds contain $\mathrm{P}$, $\mathrm{N}, \mathrm{S}, \mathrm{O}$ atoms and multiple bonds in their structure, which serve as bonding centres for their adsorption on the surface of the aluminium materials. Some of these compounds have the ability to inhibit microbial development as they can act as very

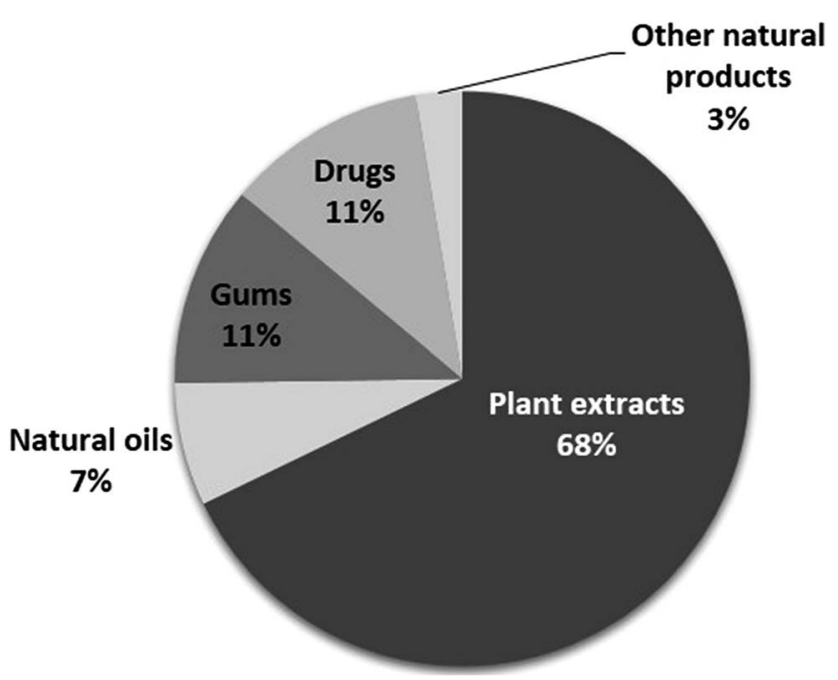

Fig. 1 Distribution of the research work performed in the last two decades on natural products as corrosion inhibitors for aluminium and its alloys presented in this review. effective reactive oxygen scavengers. Polyphenol-based extracts seem to satisfy most of the demands of a composite anticorrosion/anti-biodeterioration product, in addition to having the advantage of being less toxic than other plant extracts, e.g. alkaloid extracts. However, there is always the question of the stability of these extracts in the conditions tested as corrosion inhibitors. ${ }^{1}$

Gums and natural oils are two other groups of green corrosion inhibitors obtained from plants. In this review, drugs are considered to be green compounds as they are actually consumed by humans, however, as pointed out below, their consumed dosage is always questionable and therefore their use as green corrosion inhibitors might be questionable as well.

Several studies reported that the use of synergists, mainly KI and other halides $(\mathrm{KBr}$ and $\mathrm{KCl})$ in combination with these green inhibitors, further enhances their corrosion inhibition efficiency. ${ }^{9-17}$ The authors usually explain this phenomenon with the fact that the cation of the inhibitor adsorbs on the metal surface where the halide ions are strongly adsorbed. The adsorbed ions are stabilized through electrostatic interaction with the inhibitor molecules which leads to increase surface coverage, and therefore higher corrosion inhibition efficiency. ${ }^{\mathbf{1 8}}$

Given the complexity of the field, there is still a "barrier" between research and application. Much more research should be done regarding the analytical and micro-biological characterisation assessments of natural products tested as new ecofriendly materials protecting products for both purposes, practical and scientific, in order to achieve quality control thereof and the effectiveness of certain phytocompounds. ${ }^{\mathbf{1 9 , 2 0}}$

In the following text, we discuss the research work performed on different types of green corrosion inhibitors for aluminium and its alloys. Detailed information on the type of natural product and aluminium material tested, as well as the testing conditions (the corrosive environment and temperature), the inhibition effectiveness values (as reported by the authors), and the techniques used to evaluate them, are presented in Tables 1-8.

Recently, we presented two extensive reviews covering the use of organic compounds as corrosion inhibitors for aluminium and its alloys in acidic ${ }^{6}$ as well as in chloride and alkaline solutions. ${ }^{7}$ Both mentioned review articles summarise the research work published on this topic after the review of Jayalakshmi and Muralidharan ${ }^{21}$ in 1997 (covering organic and green corrosion inhibitors for aluminium and its alloys in various solutions). Several attempts have been made before to present the application of natural products as green corrosion inhibitors. ${ }^{22-29}$ However, these reviews discussed either green inhibitors for different metals (including aluminium and its alloys) 22-26,29 or only certain types of green inhibitors (for example extracts) for aluminium materials. ${ }^{27,28}$ To the best of our knowledge, such a comprehensive summary covering all types of green corrosion inhibitors for aluminium and aluminium alloys alone, as reported herein, has not been published in the last two decades.

This review first discusses the use of plant extracts, followed by gums, oils, and drugs employed as green corrosion inhibitors for aluminium and its alloys. Finally, the outlook as regards 


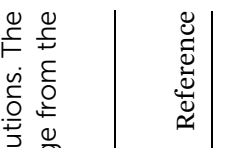

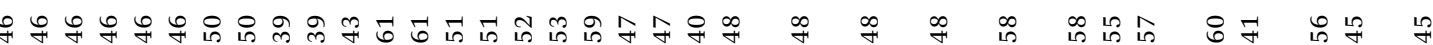

을

要学

ठำ

这部

를

党

돈

进

담

ह

高竞

广。

는

产

.ำ ऐ

Oิ

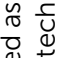

苋艺

离

总

:

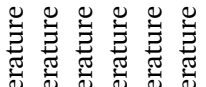

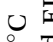

๘্

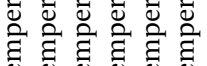

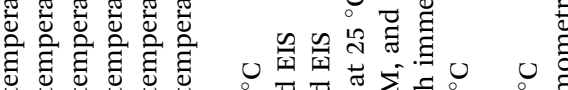

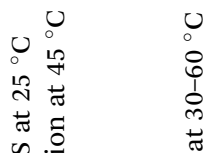

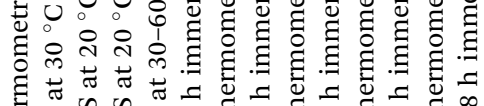

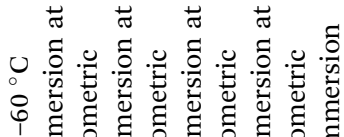

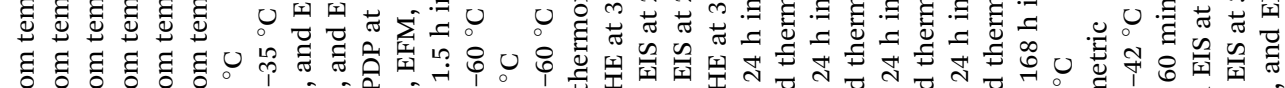

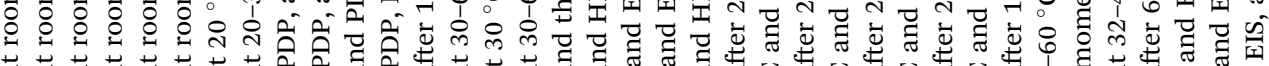

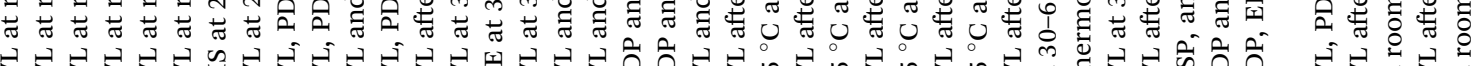

芯

$\stackrel{\circ}{\circ}$

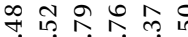

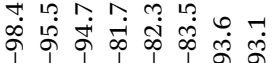

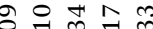

구의.

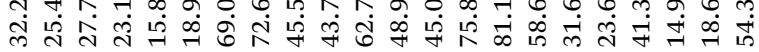

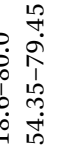

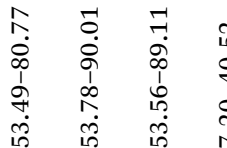

กิ

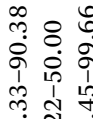

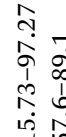

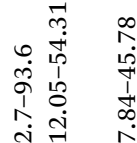

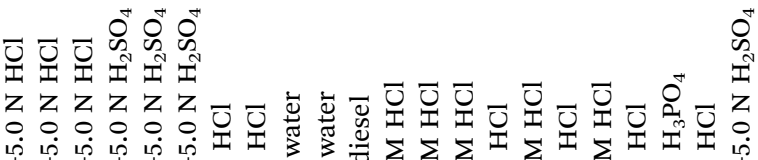

言

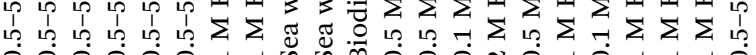

0
0
1
1
$Z$
0
10
1
10
0

$\begin{array}{ll}0 & 0 \\ 0 & 1 \\ z & z \\ 0 & 0 \\ \dot{p} & 1 \\ 1 & 1\end{array}$

0
0
0
0
1
1
0

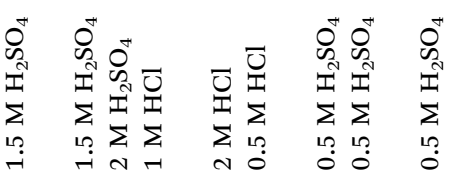

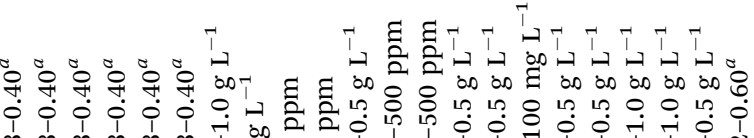
o.

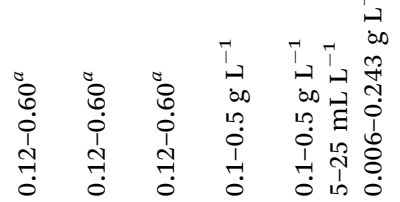

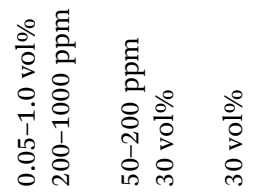

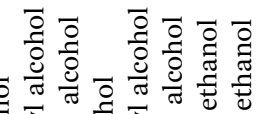

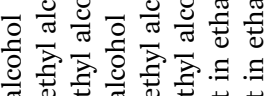

政

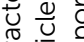

离要

$\leadsto$

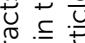

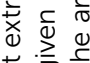

苍示声

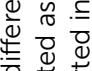

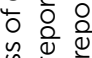

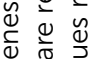

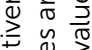

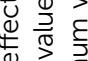

:

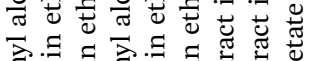

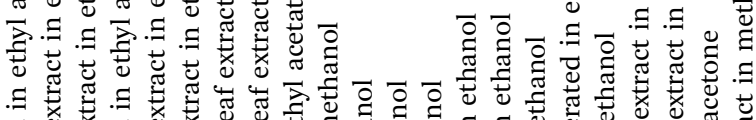

式

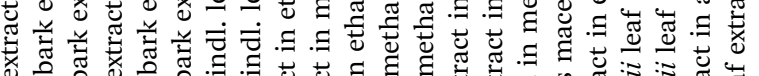

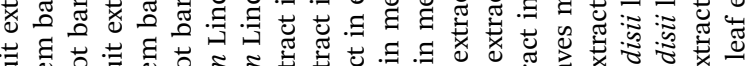

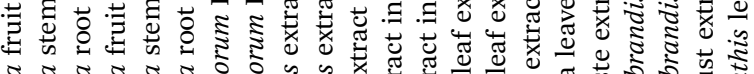

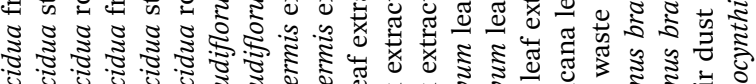

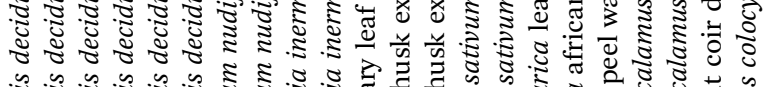

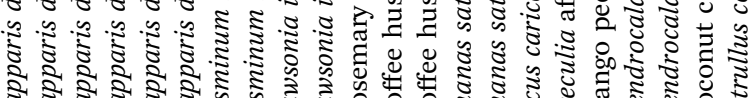

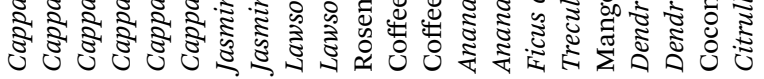

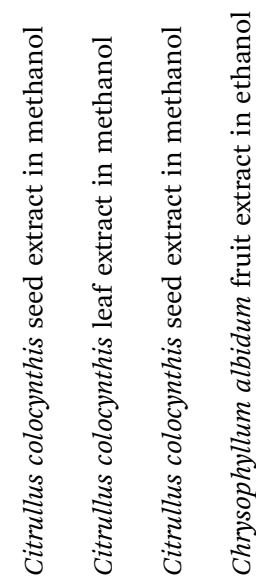

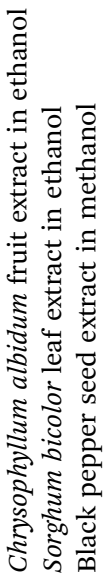

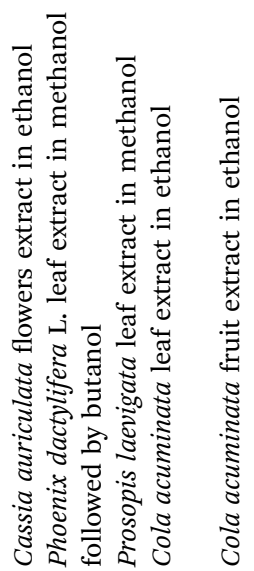

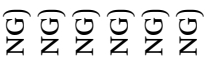

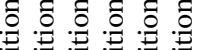

ज:

氶

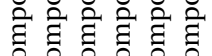

它

苞:

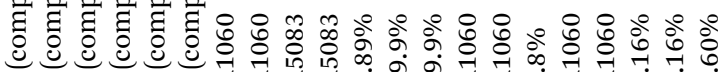

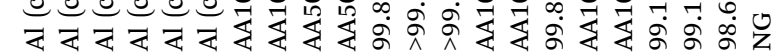




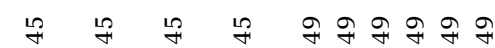

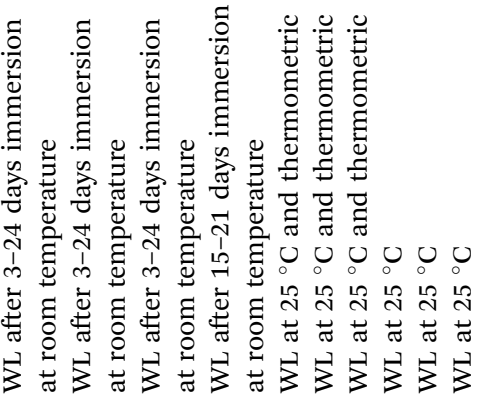

using such an approach and the evaluation of the future potential thereof is given.

\section{Plant extracts as corrosion inhibitors}

Phytocompounds and herbal-based extracts have garnered increasing interest in the field of sustainable materialprotecting products. The evaluation of some plant extracts and the correlation between the extract profile and the corrosion inhibitive effect should be focused on the total phenolic content. Indeed, a good correlation was obtained between the corrosion inhibition effectiveness of the plant extracts and their total phenolic contents. The higher the total phenolic content, the higher it is the inhibition effectiveness of the extracts. It can be argued that the total phenolic content may act as a guide for screening plant extracts for their inhibitive properties. ${ }^{30}$

\subsection{Extraction methods used to obtain plant extracts}

Numerous publications on the isolation and fractionation of different compounds such as plant extracts, essential oils, and purified compounds have appeared over the past decades. The decision on selecting the extraction method to profile the target content of plant species is related to the chemical nature of the substance, sample particle size, and also by the presence of interfering substances. ${ }^{31}$ The method used must be carefully chosen according to the aim of the research. The selection of the extraction technique has an impact on the rate, yield, and purity and is influenced by the niche of the compound of interest and the degree of purity required.

The type of extraction solvent as well as the isolation procedures may have a significant impact on the extraction yield of substances from plants material. Each extraction technique certainly has unique operating factors that affect the concentration and antioxidant activity of the extract, and need to be optimised. The extraction time, temperature, solvent-tofeed ratio, number of repeated extractions of the sample, as well as the choice of extraction solvents, are the main parameters controlling extraction kinetics. Solubility is highly affected by the extraction time and temperature. At a higher extraction temperature, the viscosity and surface tension of solvents decrease, which accelerates the mass transfer rate. ${ }^{32}$ An additional parameter controlling the extraction kinetics is the material pretreatment, which affects the moisture content, sample matrix, particle size, and distribution.

Conventional liquid-liquid and solid-liquid extraction techniques are still commonplace due to their simplicity, efficiency, and wide-ranging applicability. However, these traditional methods have their own advantages and limitations. Solvent-based extraction results in a higher yield. The main drawbacks of this technique are related to the use of conventional solvents such as alcohols (methanol, ethanol, isopropanol), acetone, diethyl ether, and ethyl acetate, often mixed with different proportions of water for sample preparation, separation, and detection, and the identification are of both environmental and economic concern. Additional purification 
steps either by membrane or ultrafiltration are required to meet regulation requirements. Exposure to a higher temperature for a prolonged period of time may lead to a rapid degradation of active compounds. Long extraction time is yet another problem facing the conventional extraction procedure. ${ }^{33}$

Modern extraction techniques are centred on reducedsolvent methods, sorption-based methods, environmental applications, and on both solid and liquid samples. ${ }^{34}$

Supercritical fluid extraction (SFE), pressurised-liquid extraction (PLE), microwave-assisted extraction (MAE), solidphase extraction (SPE), and solid-phase microextraction (SPME) offer important advantages over organic solvent technology, such as ecological friendliness and ease of product fractionation. These methods became interesting due to their simplicity, shorter extraction times, and the lower release of toxic pollutants by reducing organic solvent consumption. The most important advantage of SFE is the selective extraction of components or the fractionation of the total extracts. ${ }^{35}$ This is possible with the use of different gases for isolation/ fractionation of the components and/or by changing the process parameters. Sub- and supercritical fluids are widely accepted as non-carcinogenic, non-toxic, non-mutagenic, nonflammable, and thermodynamically stable solvents. A supercritical fluid is any substance at a temperature and pressure above its critical point, where distinct liquid and gas phases do not exist. They represent a suitable substitute for organic solvents which close to the critical point show a unique feature, i.e. small changes in pressure or temperature result in large changes in density, allowing their many properties to be "finetuned". In the pressure-temperature phase diagram (Fig. 2), the boiling curve separates the gas and liquid region and ends in the critical point, where the liquid and gas phases disappear and only a single supercritical phase is present.

On the other hand, the main feature of the extraction procedures described above is their suitability for isolation of both, polar and non-polar compounds and selectivity is fine-

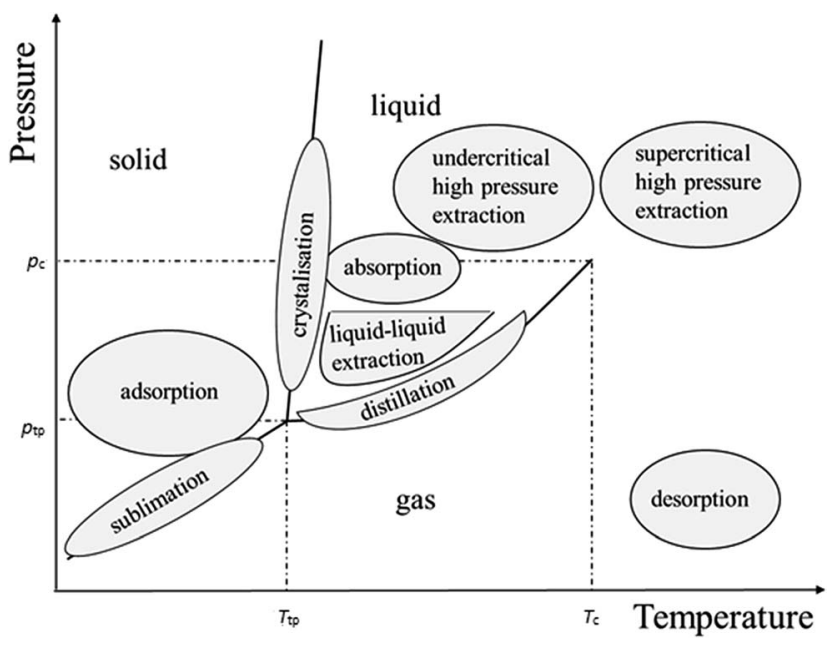

Fig. $2 p-T$ diagram of a pure substance and separation processes. $T_{C}$ and $p_{\mathrm{c}}$ are the critical temperature and pressure, while $T_{\mathrm{tp}}$ and $p_{\mathrm{tp}}$ are the triple point temperature and pressure, respectively. tuned by selection of proper solvent and/or operating conditions. Studies on the nature of corrosion inhibitors demonstrate that polar as well as non-polar compounds show corrosion inhibition effectiveness. In addition, the extraction procedures listed above are beneficial from the economic point of view. As reported in this review polyphenols are among the main components of the green corrosion inhibitors tested. The highest yields of polyphenols are usually achieved with ethanol and methanol and their mixtures with water, although other solvents have been widely used for extraction of polyphenols from plants, as ethyl acetate or acetone.

Given the complexity of the field, it may be concluded that, in practice, there is still a "barrier" between research and application. Much more research should be done regarding analytical and micro-biological characterisation assessments on vegetal extracts tested as new eco-friendly material-protecting products for both purposes, practical and scientific, in order to achieve the quality control of vegetal extracts and the effectiveness of certain phytocompounds..$^{19,20}$

In the following text, we discuss in more details the research work published in the last two decades on plant extracts as corrosion inhibitors for aluminium and its alloys in various corrosive environments. Information on the extraction technique as well as the main components of the extracts (as reported by the authors in the given corrosion inhibition research, or in other studies not strictly related to corrosion research), is also given. The extracts have been divided into four groups, based on the solvents used for the extraction. The main findings (as described above) regarding the use of plant extracts as corrosion inhibitors for aluminium materials are presented in Tables 1-4.

\subsection{The corrosion inhibition of plant extracts obtained by means of organic solvents}

Organic solvents are commonly used to extract phenolic compounds from agricultural tissue. Pretreatment of raw material with hexane to remove lipids is commonly the first step of conventional organic solvent extraction, as ground plant material may be extracted in a Soxhlet apparatus. Polyphenols contain multiple phenolic functionalities with diverse chemical structures and properties. Since it is generally known that the yield of chemical extraction depends on the type of solvent with varying polarities, extraction time, and temperature, the massto-solvent ratio, and the chemical composition and physical characteristics of the samples, much attention is devoted to the choice of the most suitable organic solvent. Methanol, ethanol, acetone, ethyl acetate, and their combinations are known for their high efficiency in the extraction of phenolics from plant materials, often with different proportions of water. In particular, methanol has been proved to be a selective solvent for the extraction of lower molecular weight polyphenols. High molecular weight flavanols are usually efficiently extracted with aqueous acetone. ${ }^{36-38}$

Ethanol is known to be safe for human consumption and is employed for the extraction of anthocyanin-rich phenolic species from plant tissues. Ethyl acetate or ethanol are usually 


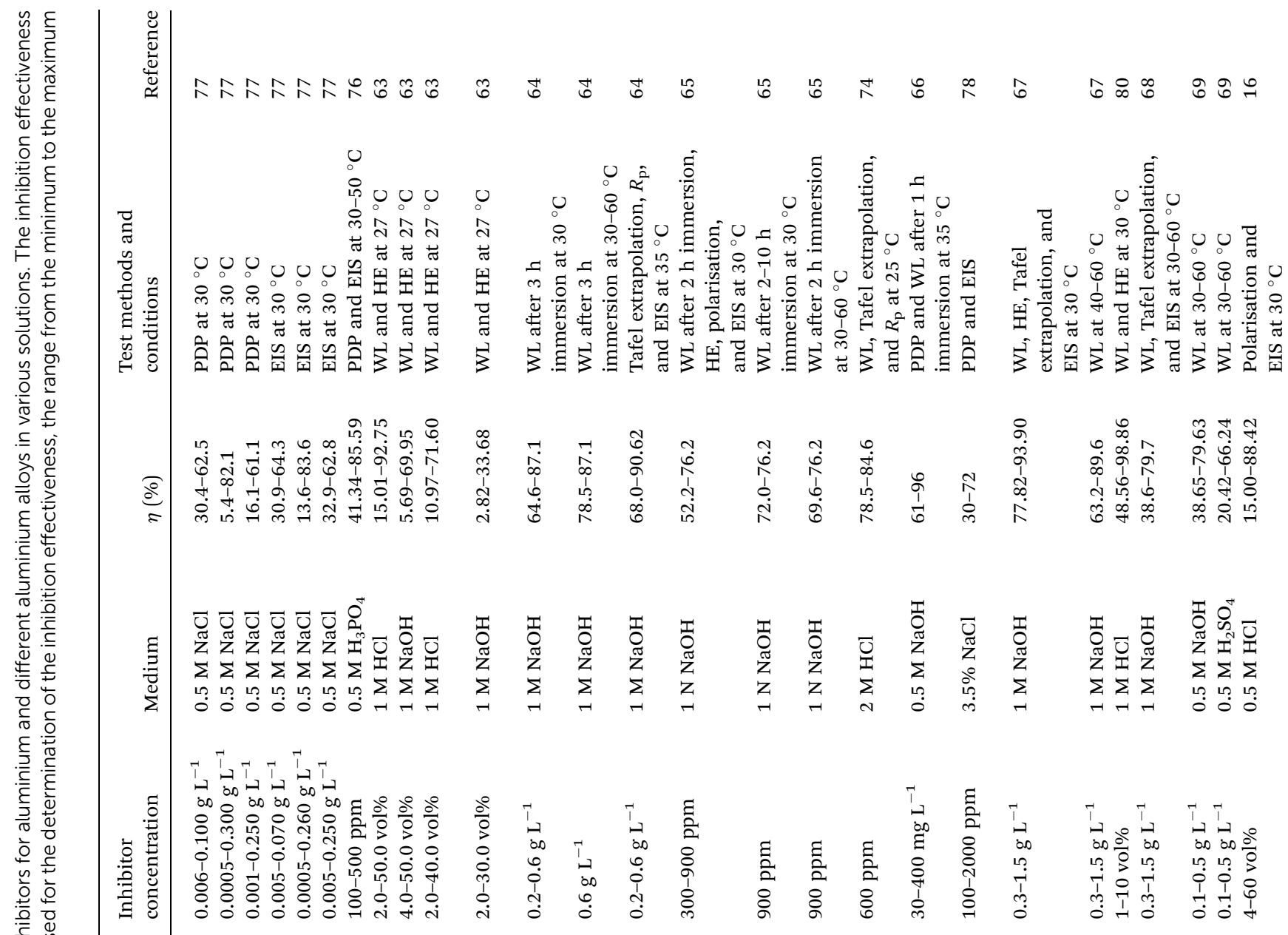




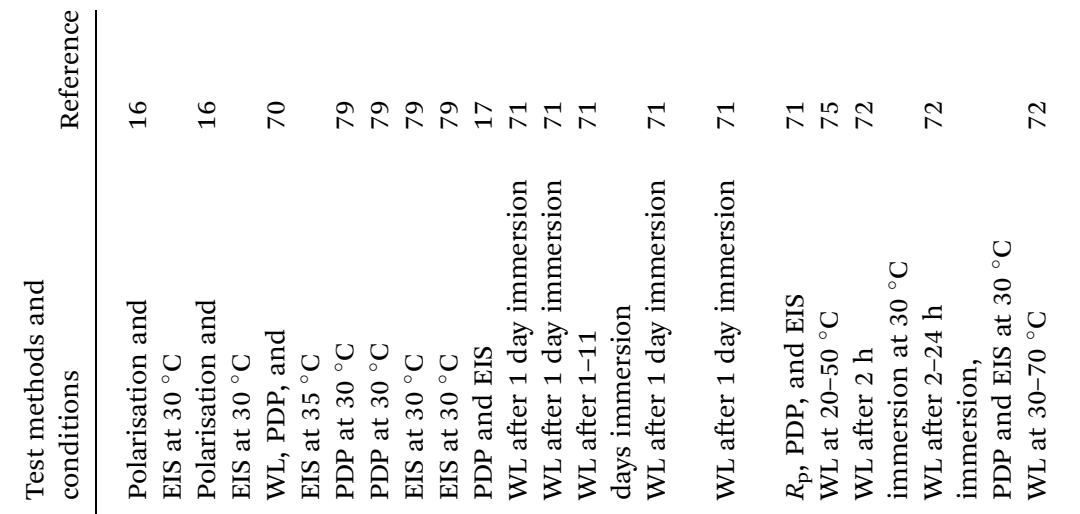

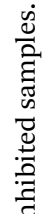

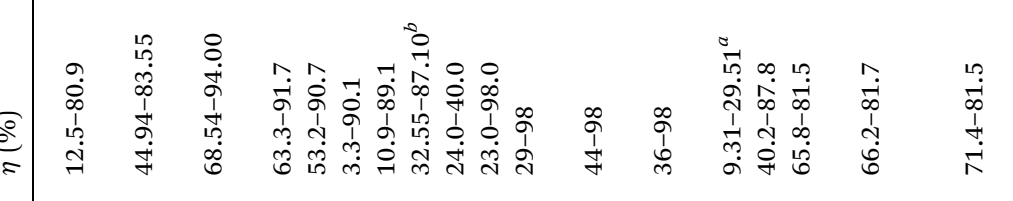

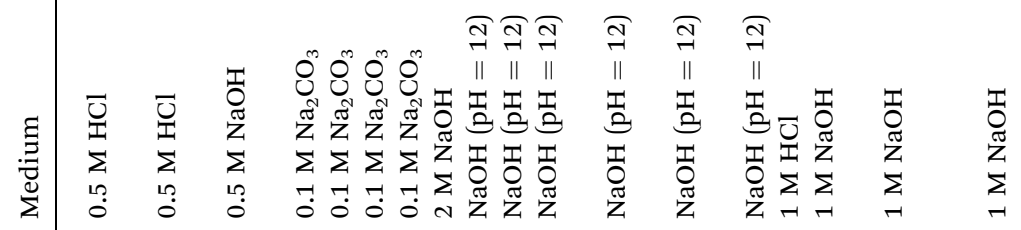

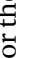

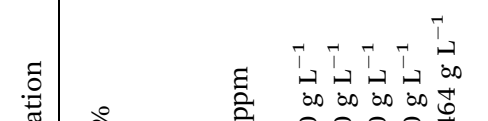

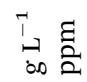

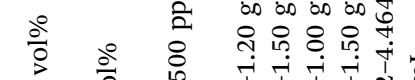<smiles>[SiH3][AsH2]</smiles>
is 2

ह $\quad$ ह

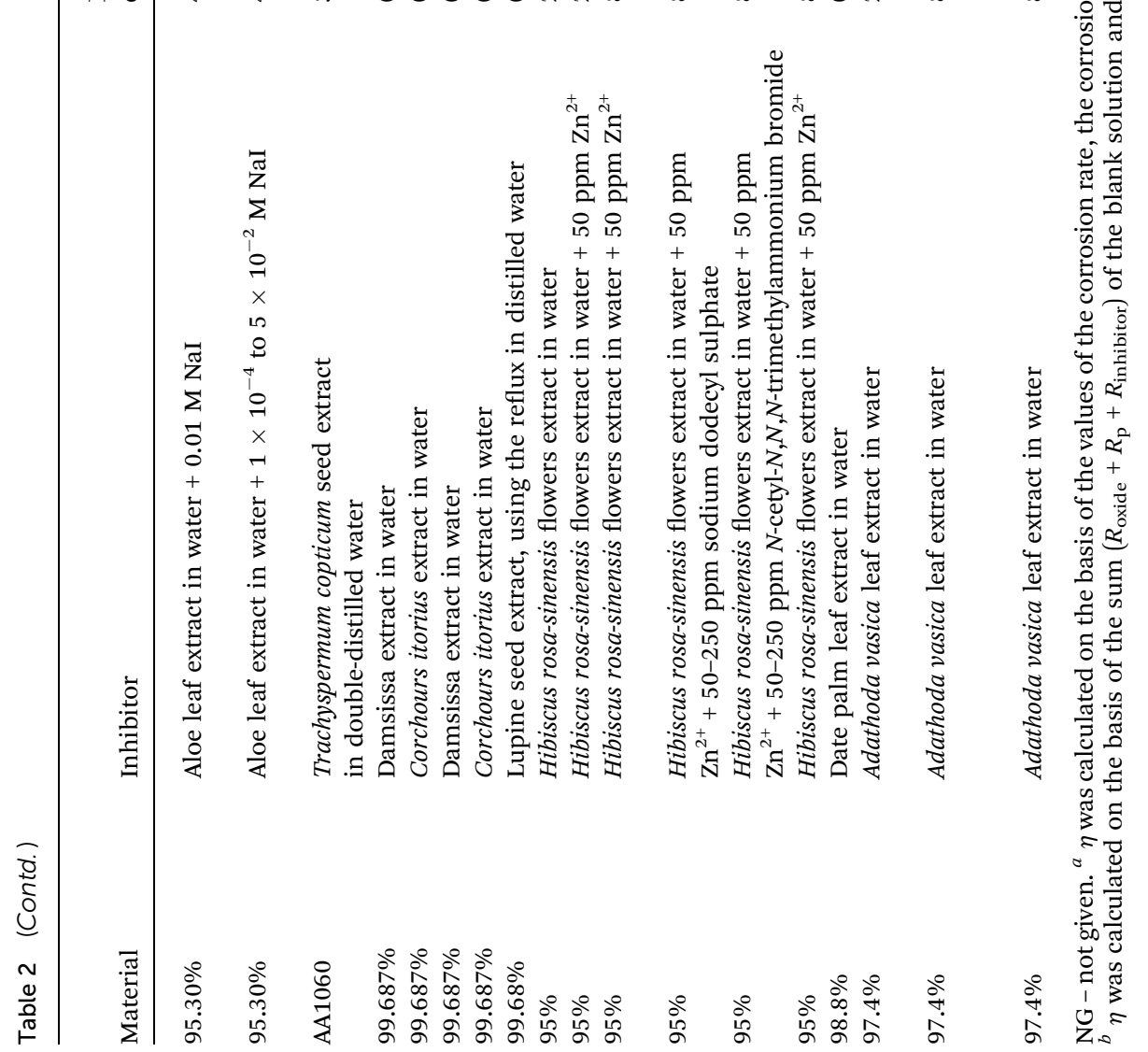


applied to obtain flavonoids. Sequential solvent extraction is being used increasingly often; the material is first extracted with dichloromethane. This step comprises the isolation of flavonoid aglycones and other components of lower polarity. A serious drawback of dichloromethane is its toxicity. In the subsequent step, flavonoid glycosides and polar constituents are extracted using a suitable alcohol. ${ }^{37,38}$

As seen in Table 1, methanol and ethanol were widely used as solvents in the performed studies. However, other organic solvents, such as ethyl acetate, ${ }^{39}$ acetone, ${ }^{40}$ and methanol followed by butanol, ${ }^{\mathbf{4 1}}$ have also been employed. The extracts obtained were used to protect mostly pure aluminium and 1xxx series aluminium alloys in acidic solutions. Only a few studies reported the inhibition effectiveness of the extracts in chloridecontaining solutions, ${ }^{39,42}$ or even in biodiesel. ${ }^{43}$ The inhibition effectiveness of all studied extracts increased with increasing concentration, independently of their type, corrosive environment, or material. However, Nnaji et al. ${ }^{\mathbf{4 4}}$ investigated the inhibition effectiveness of cashew nut (Anacardium occidentale) testa extract in acetone as a corrosion inhibitor for AA1060 aluminium alloy in $0.1,0.5$, and $2.0 \mathrm{M} \mathrm{HCl}$ solutions at 30$50{ }^{\circ} \mathrm{C}$. It was reported that the inhibition effectiveness increased with increasing extract concentration in 0.5 and $2.0 \mathrm{M} \mathrm{HCl}$ solutions, while in $0.1 \mathrm{M} \mathrm{HCl}$ solution a decrease in the inhibition effectiveness was observed with increasing extract concentration. Moreover, Loto and Popoola ${ }^{45}$ studied the inhibition effectiveness of the ethanol extracts of cola acuminate leaves and fruit and Nicotiana leaves as corrosion inhibitors for $2 \mathrm{~S}$ aluminium alloys in 0.5 and $1 \mathrm{M} \mathrm{H}_{2} \mathrm{SO}_{4}$ solution at room temperature. The authors reported no clear trend in the inhibition effectiveness at the different concentrations tested. In some cases certain concentrations even promoted corrosion.

Arora et al., ${ }^{46} \mathrm{Li}$ and Deng, ${ }^{47}$ Chauhan et al.,${ }^{48}$ and Jain et al. ${ }^{\mathbf{4 9}}$ investigated the inhibition effectiveness of extracts as a function of the corrosive environment. Arora et $a .^{46}$ tested the extracts of Capparis decidua fruits, stem bark, and root bark in ethyl alcohol as inhibitor in the corrosion of aluminium in 0.5$5.0 \mathrm{~N} \mathrm{HCl}$ and $0.5-5.0 \mathrm{~N} \mathrm{H}_{2} \mathrm{SO}_{4}$ solutions, at room temperature. The authors reported a higher inhibition effectiveness of all types of extract in $\mathrm{HCl}$ compared to $\mathrm{H}_{2} \mathrm{SO}_{4}$ solution.

The same conclusion was reported also by Chauhan et al. ${ }^{\mathbf{4 8}}$ who evaluated the inhibition effectiveness of Citrullus colocynthis leaf and seed extracts in methanol as corrosion inhibitors for aluminium in 0.5-5.0 $\mathrm{N} \mathrm{H}_{2} \mathrm{SO}_{4}$ and $0.5-5.0 \mathrm{~N} \mathrm{HCl}$ solutions at $25{ }^{\circ} \mathrm{C}$. The inhibition effectiveness increased with increasing concentration of both acids.

Jain et al. ${ }^{49}$ studied the inhibition effectiveness of Ficus virens seed, leaf, and bark extracts in methanol as corrosion inhibitors for aluminium in 0.1-4.0 N HCl and 0.1-4.0 $\mathrm{N} \mathrm{H}_{2} \mathrm{SO}_{4}$ solutions at $25{ }^{\circ} \mathrm{C}$. The authors showed that the extracts protected aluminium better in $\mathrm{HCl}$ than in $\mathrm{H}_{2} \mathrm{SO}_{4}$ solutions. A methoxy derivative of alstonine (11-mithoxy tetrahydroalstonine) named aricine is reported as the main component of Ficus virens.

The inhibition effectiveness of Dendrocalumus brandisii leaf extract in ethanol as a corrosion inhibitor for $99.16 \%$ aluminium alloy in $1 \mathrm{M} \mathrm{HCl}$ and $1 \mathrm{M} \mathrm{H}_{3} \mathrm{PO}_{4}$ solutions at $20{ }^{\circ} \mathrm{C}$ was evaluated by $\mathrm{Li}$ and Deng. ${ }^{47}$ The authors reported that polyflavonols, thiols, anthocyanins, and tannins are the main components of the extract. Advantageously, the extraction procedure does not affect the content of the target compounds since it requires only moderate operating temperatures. A significant decrease in the inhibition effectiveness of the extract was reported in $\mathrm{H}_{3} \mathrm{PO}_{4}$ compared to $\mathrm{HCl}$ solution. The inhibition effectiveness of the extract increased with increasing immersion time up to $2 \mathrm{~h}$ for both acids and then gradually decreased for longer immersion times. The concentration of the acids was found to influence the inhibition effectiveness of the extract. The later increased at low acid concentrations (0.5-1.0 $\mathrm{M})$, but significantly decreased for higher concentrations (1.03.0 M).

The extracts tested as corrosion inhibitors were obtained from different parts of the plants, including leaves, ${ }^{\mathbf{4 1 , 4 3 , 4 5 , 4 7 - 5 7}}$ stem and root bark, ${ }^{42,46,49}$ fruits $^{45,46,54,58}$ and fruit peel, ${ }^{59}$ seeds, ${ }^{48,49,57}$ flowers ${ }^{60}$ husks, ${ }^{61}$ and nuts. ${ }^{44}$ Wan Nik et al. ${ }^{39}$ gave no clear indication as to which part of Lawsonia inermis was selected to prepare the extract. The distribution of active compounds in different parts of plants, such as such as leaves, stems, roots, and fruit, shows qualitative and quantitative variations. Often different parts of the same plant contain completely different compounds. ${ }^{62}$ Several studies have been performed evaluating the inhibition effectiveness of different parts of the same plant extracted with the same solvent. ${ }^{45,46,48,49,54}$ Capparis decidua fruit extract in ethyl alcohol showed higher inhibition effectiveness in both $\mathrm{HCl}$ and $\mathrm{H}_{2} \mathrm{SO}_{4}$ solutions compared to stem bark and root bark extracts from the same plant. ${ }^{46}$ No significant change in the inhibition effectiveness was reported between the stem bark and root bark in $\mathrm{HCl}$ solution, while in $\mathrm{H}_{2} \mathrm{SO}_{4}$ solution the root bark extract protected aluminium better. Ficus virens extracts of seeds, leaves, and bark in methanol showed no significant difference in the $\eta$ values in $\mathrm{HCl}$ solution, while in $\mathrm{H}_{2} \mathrm{SO}_{4}$ solution the inhibition effectiveness followed the order bark extract $>$ leaf extract $>$ seed extract. ${ }^{49}$ Kumar and Mathur ${ }^{54}$ investigated the ethanolic extracts of the leaves, latex, and fruit of Calotropis procera and Calotropis gigantea as corrosion inhibitors for 98.79\% aluminium in 0.5-5.0 $\mathrm{N} \mathrm{H}_{2} \mathrm{SO}_{4}$ solutions. However, the data showed only non-significant differences in the $\eta$ values of the three types of extracts. The same behaviour was reported by Chauhan et al. ${ }^{48}$ regarding Citrullus colocynthis leaf and seed extracts in methanol. Furthermore, no clear distinction as to the inhibition performance of ethanolic extracts of Cola acuminate leaves and fruits was reported by Loto and Popoola. ${ }^{45}$

The inhibition effectiveness of the tested extracts was investigated in a temperature range from $20{ }^{\circ} \mathrm{C}$ to $60{ }^{\circ} \mathrm{C} .{ }^{40-42,44,47,50-53,55,56,58,59,61}$ In the majority of the abovementioned studies it was reported that the inhibition effectiveness of the respective extracts decreased with increasing temperature, apart from the works of Ating et al. ${ }^{51}$ and Umoren et $a l .{ }^{40}$ Ating et al. ${ }^{51}$ studied the inhibition effectiveness of the extract of Ananas sativum leaves in ethanol as an inhibitor for AA1060 aluminium alloy in $0.1 \mathrm{M}$ and $2.0 \mathrm{M} \mathrm{HCl}$ solutions at 30-60 ${ }^{\circ} \mathrm{C}$. Umoren et al. ${ }^{40}$ tested the inhibition effectiveness of coconut (Cocos nucifera) coir dust extract in acetone as a corrosion inhibitor for $\mathrm{Al}$ 3SR (98.60\% aluminium) aluminium alloy 
in $1 \mathrm{M} \mathrm{HCl}$ solution at 30 and $60^{\circ} \mathrm{C}$. According to the authors, coconut coir dust extract contains a mixture of alkaloids, flavonoids, and organic acids, without identifying any compound in particular.

The change in the inhibition effectiveness with temperature was found to be dependent on the corrosion environment in the case of Dendrocalamus brandisii leaf extract in ethanol. ${ }^{47}$ The authors reported that the inhibition effectiveness of the extract decreased with increasing temperature in $\mathrm{HCl}$ solutions, while remained almost constant in $\mathrm{H}_{3} \mathrm{PO}_{4}$ solutions.

PDP measurements revealed different behaviour of the extracts in terms of influencing the anodic, cathodic, or both corrosion reactions of the corrosion couple. Deng and $\mathrm{Li}^{50}$ studied the inhibition effectiveness of the ethanol extract of Jasminum nudiflorum Lindl. leaf in the corrosion of AA1060 aluminium alloy in $1 \mathrm{M} \mathrm{HCl}$ solution at $20-35^{\circ} \mathrm{C}$ and concluded that the extract acted as a cathodic-type inhibitor. The same behaviour was reported for Prosopis laevigata leaf extract in methanol ${ }^{56}$ used as a corrosion inhibitor for aluminium in $0.5 \mathrm{M} \mathrm{H}_{2} \mathrm{SO}_{4}$ solution at $30{ }^{\circ} \mathrm{C}$. Based on the PDP measurements, Li and Deng ${ }^{47}$ concluded that Dendrocalumus brandisii leaf extract acted as a cathodic-type inhibitor in $\mathrm{HCl}$ solutions, but as a mixed-type inhibitor in $\mathrm{H}_{3} \mathrm{PO}_{4}$ solutions. Prosopine and prosopinine were reported to be the main constituents of the extract.

Singh et al. $^{42}$ used Berberine (5,6-dihydro-9,10-dimethoxybenzo[g]-1,3-benzodioxolo[5,6- $a]$ quinolizinium), a compound obtained from the extraction of dried Coptis chinensis roots in ethanol, as an inhibitor in the corrosion of AA7075 aluminium in $3.5 \% \mathrm{NaCl}$ solution at $25-60{ }^{\circ} \mathrm{C}$, and, based on the PDP measurements, concluded that the extract acted as a mixed-type inhibitor. Mixed-type inhibition was reported also for Cassia auriculata flower extract in alcohol ${ }^{60}$ and coffee (Coffea) husk extract in methanol. ${ }^{61}$ Cassia auriculata flower extract in alcohol $^{60}$ was tested as a corrosion inhibitor for $97.704 \%$ aluminium alloy in $2 \mathrm{M} \mathrm{HCl}$ solution at $30{ }^{\circ} \mathrm{C}$. It was reported that luteolin-7-o-glucoside is the main component of the extract. The main drawback is the extraction procedure, which is rather complicated and involves isolation steps using different organic solvents. Coffee (Coffea) husk extract in methanol ${ }^{61}$ was used as a corrosion inhibitor for aluminium with purity higher than $99.9 \%$ in $0.5 \mathrm{M} \mathrm{HCl}$ solution at 25 and $45{ }^{\circ} \mathrm{C}$. The authors reported that the main components in coffee husk are cellulose, hemicellulose, pectin, lignin, caffeine, tannin, and polyphenol.

Several authors reported that the respective extracts acted as mixed-type inhibitors, but with a predominant action on either the cathodic or anodic corrosion reaction. In fact, Wan Nik et $a l .{ }^{39}$ studied the inhibition effectiveness of Lawsonia inermis extracts in ethyl acetate and in methanol as corrosion inhibitors for AA5083 aluminium alloy in sea water (no composition given) and concluded that the extracts acted as mixed-type inhibitors, with a predominant effect on the cathodic reaction. The same conclusion was reached by Divya et al., ${ }^{57}$ who evaluated the inhibition effectiveness of black pepper (Piper nigrum) seed extract in methanol as a corrosion inhibitor for $99.2 \%$ aluminium in $1 \mathrm{M} \mathrm{HCl}$ solution at $35{ }^{\circ} \mathrm{C}$. Next, Shalabi et al. ${ }^{41}$ studied the inhibition effectiveness of Phoenix dactylifera $\mathrm{L}$. leaf extract in methanol followed by butanol as a corrosion inhibitor for $99.55 \%$ aluminium and $92.482 \% \mathrm{Al}-\mathrm{Si}$ alloy at $20-60{ }^{\circ} \mathrm{C}$ and, based on the PDP measurements, reported that the extract acted as a mixed-type inhibitor, with predominant action on the cathodic corrosion reaction. The main components of the extract were reported to be gallic acid, protocatechuic acid, caffeic acid, $\beta$-carotene, and lutein. The extract protects $\mathrm{Al}-\mathrm{Si}$ alloy better compared to aluminium.

Only Deyab ${ }^{43}$ reported that rosemary (Rosmarinus officinalis) leaf extract in ethanol acted as a mixed-type inhibitor, with a predominant effect on the anodic corrosion reaction of 99.89\% aluminium in biodiesel at $25{ }^{\circ} \mathrm{C}$.

In general, when explaining the inhibition action of the extracts, the authors refer to their ability to adsorb on the aluminium material surface through the adsorption centres contained in the constituents of these extracts. In most of the cases they do not specify which compound or compounds are responsible for the adsorption. This is the case in the works of Yiase et $a l .{ }^{55}$ and Madufor et al. ${ }^{58}$ and Ukpe et al. ${ }^{59}$ Yiase et al. ${ }^{55}$ reported on the inhibition effectiveness of Sorghum bicolor leaf extract in ethanol as a corrosion inhibitor for $99.8 \%$ aluminium in $2 \mathrm{M} \mathrm{H}_{2} \mathrm{SO}_{4}$ solution at $32-42{ }^{\circ} \mathrm{C}$. Madufor et al. ${ }^{58}$ studied the inhibition effectiveness of Chrysophyllum albidum fruit extract in ethanol as a corrosion inhibitor for AA1050/1070 (99.0\% Al) aluminium alloy in $1.5 \mathrm{M} \mathrm{H}_{2} \mathrm{SO}_{4}$ solution, at 30-60 ${ }^{\circ} \mathrm{C}$. Ukpe et $a .^{59}$ reported on the inhibition effectiveness of mango (Mangifera) fruit peel waste extract in ethanol as a corrosion inhibitor for AA1060 aluminium alloy (98.5\% purity) in $0.1 \mathrm{M}$ $\mathrm{HCl}$ solution at $30-60{ }^{\circ} \mathrm{C}$. Based on the thermodynamic calculations, as well as the change in the inhibition effectiveness with temperature, the authors discussed the possible adsorption mechanism for the extracts on the aluminium material surface. All three authors above ${ }^{55,58,59}$ suggested that the extracts physisorbed on the aluminium materials.

Nnaji et $a .^{44}$ reported that quercetin, azaleatin, catechin, epicatechin, cyaniding, and dephinidin are among the main components of cashew nut (Anacardium occidentale) testa extract in acetone. Based on the quantum chemical parameters, the authors suggested that the extract adsorbed on the aluminium surface through the aromatic $\mathrm{C}=\mathrm{C}, \mathrm{C}=\mathrm{O}$, and $\mathrm{O}-\mathrm{H}$ sites contained in the protonated forms of the extract components. Physisorption was the proposed mechanism for the adsorption of cashew nut testa extract on the alloy surface.

Physisorption seems to be the common mechanism suggested by authors in general. Onen et al. ${ }^{52}$ suggested physisorption as the possible mechanism for the adsorption of Ficus carica leaf extract in methanol on the surface of $99.8 \%$ aluminium immersed in $0.5 \mathrm{M} \mathrm{HCl}$ solution at $30-60{ }^{\circ} \mathrm{C}$. Ejikeme et $a l .{ }^{53}$ reported that the main components found in Treculia africana leaf extract in 96\% ethanol are alkaloids, flavonoids, terpenes, and proteins. These components physisorbed on the alloy surface to inhibit the corrosion of AA1060 aluminium alloy in $1 \mathrm{M} \mathrm{HCl}$ solution at 30 and $60{ }^{\circ} \mathrm{C}$. Physisorption was also suggested for rosemary leaf extract in ethanol, ${ }^{43}$ Dendrocalumus brandisii leaf extract in ethanol, ${ }^{47}$ and Jasminum nudiflorum Lindl. leaf extract in ethanol, ${ }^{50}$ while 
Fouda et al. ${ }^{61}$ concluded that the inhibition is due to adsorption on the aluminium surface through electrostatic interactions for coffee husk extract in methanol. A few studies report a chemisorption mechanism for the tested extracts ${ }^{\mathbf{4 0 , 5 1 , 5 6}}$ and only Divya et $a l .{ }^{57}$ suggested that the main constituent of black pepper seed extract in methanol, piperine, followed by $E$-caryophyllene and 9-octadecynoic acid, adsorbed through a mixed-type mechanism (both physisorption and chemisorption) on the aluminium surface.

In addition, in a few studies the inhibition action of the extracts was attributed to the formation of a surface layer as a result of the adsorption of the extracts' components on the aluminium materials. This surface layer protected the materials from further attack from the corrosive environment. ${ }^{39,42,57}$ Singh et al. $^{\mathbf{4 2}}$ attributed the decrease in inhibition effectiveness with increasing temperature to the dissolution of this protective surface layer.

Lower extraction temperatures and the omission of large amounts of organic solvents will certainly contribute to a higher yield of phenolic compounds in the final product. Some authors $^{\mathbf{4 3 - 4 7 , 5 0 , 5 2 , 5 6 , 6 1}}$ report easy, economically feasible extraction procedures carried out at low temperatures with a low consumption of chemicals. Modern extraction techniques certainly represent a green solution to obtain extracts of high quality. Despite the high extraction temperatures and use of organic solvents, Arora et al. ${ }^{\mathbf{4 6}}$ reported a high inhibitive effectiveness for the ethanolic extracts of Capparis decidua. The main drawback of the extraction procedure is probably its duration, which takes several days. Additionally, further purification steps are required to remove solvent residues from the obtained extracts.

\subsection{The corrosion inhibition of aqueous plant extracts}

A considerable number of studies have investigated the inhibition effectiveness of different parts of plants extracted with water (Table 2). Aluminium materials similar to what was reported for the extracts obtained with organic solvents were studied for these extracts, mainly for pure aluminium and 1xxx and $7 \mathrm{xxx}$ series aluminium alloys. However, there is a clear distinction in the corrosive environments tested. The aqueous extracts were tested in various corrosion environments, mainly alkaline, ${ }^{17,63-73}$ but also acidic ${ }^{16,63,69,74-76}$ and salts. ${ }^{77-79}$ Two studies discussed the possible effect of the corrosive environment on the inhibition effectiveness of the extract. Umoren et $a .^{69}$ tested the aqueous extract of Vigna unguiculata husk as an inhibitor in the corrosion of AA1060 aluminium alloy in $0.5 \mathrm{M} \mathrm{H}_{2} \mathrm{SO}_{4}$ and $0.5 \mathrm{M} \mathrm{NaOH}$ solutions at 30 and $60{ }^{\circ} \mathrm{C}$. The extract showed higher inhibition effectiveness in $\mathrm{NaOH}$ than in $\mathrm{H}_{2} \mathrm{SO}_{4}$ solution. Emran et al. ${ }^{63}$ tested the inhibition effectiveness of cantaloupe (Cucumis melo) pulp extract obtained with a blender and cantaloupe (Cucumis melo) seed extract in doubledistilled water, as corrosion inhibitors for 32177 aluminium alloy $(97.025 \% \mathrm{Al})$ in $1 \mathrm{M} \mathrm{HCl}$ and $1 \mathrm{M} \mathrm{NaOH}$ solutions at $27^{\circ} \mathrm{C}$. The extracts protected the aluminium alloy better in $\mathrm{HCl}$ than in $\mathrm{NaOH}$ solution. In the same study the authors extracted two different parts of the cantaloupe plant, i.e. pulp and seeds. They reported that the pulp extract is more effective compared to the seed extracts in both alkaline and acidic solutions.

Leaves, ${ }^{16,67,68,72,74,75}$ seeds, ${ }^{17,63,70,73,76,80}$ pulp and fruit juice, ${ }^{63,78}$ bark and stem, ${ }^{64,66}$ and husk and flowers ${ }^{69,71}$ were the plant parts used to prepare the extracts. No indication of what parts of the plants were used to prepare extracts was given in the works of Fetouh et $a .^{77}$ and Abd-El-Nabey et al. ${ }^{79}$ Although the general trend in all the published works is that the inhibition effectiveness increased with increasing extract concentration, there are a few exceptions. ${ }^{72,74,77}$ Fetouh et al. $^{77}$ evaluated the inhibition effectiveness of the aqueous extracts of Ambrosia maritima L. (damsissa), Lupinus sp. L (lupine), and Cymbopogon proximus (halfa-bar) as corrosion inhibitors of AA7075-T6 aluminium alloy in $0.5 \mathrm{M} \mathrm{NaCl}$ solution at $30{ }^{\circ} \mathrm{C}$. The main active compounds in Damsissa extract are ambrosin and damsin. Lupanine, multiflorine, and sparteine were the main components of the Lupine extract. The most abundant components in the halfa-bar extract are proximadiol, $5 \alpha$ hydroxy- $\beta$-eudesmol, $5 \alpha$-hydroperoxy- $\beta$-eudesmol, and $1 \beta$ hydroxy- $\beta$-eudesmol. The inhibition effectiveness of all three extracts increased with increasing concentration, up to a certain concentration, and then decreased with a further increase in the extract concentration. The authors reported that the highest inhibition effectiveness was obtained for lupine extract, while the lowest inhibition effectiveness for halfa-bar extract. Next, Soror $^{74}$ studied the inhibition effectiveness of the aqueous extract of saffron (Crocus sativus) leaves as a corrosion inhibitor for $99.99 \%$ aluminium in $2 \mathrm{M} \mathrm{HCl}$ solution at $25{ }^{\circ} \mathrm{C}$. It was reported that the main components of the saffron extract are safranal, crocin, zeaxanthin, picrocrocin, crocetin, and decyl glucoside. The inhibition effectiveness increased with increasing saffron leaf extract concentration up to $600 \mathrm{ppm}$ and then decreased for higher concentrations. Finally, Prabha et $a .^{72}$ tested the aqueous extracts of Adathoda vasica leaves as corrosion inhibitors in the corrosion of $97.4 \%$ aluminium in $1 \mathrm{~N}$ $\mathrm{NaOH}$ solution at $30-70{ }^{\circ} \mathrm{C}$. The inhibition effectiveness increased with an increase in the extract up to $800 \mathrm{ppm}$. No improvement in the inhibition effectiveness was observed for concentrations higher than $800 \mathrm{ppm}$. Apart from aqueous extracts of this plant, the presence of phenols, tannins, alkaloids, anthraquinones, saponins, flavanoids, aminoacids, and reducing sugars was found to be relatively high also for ethanol and petroleum ether extracts. ${ }^{62}$

The synergistic effect of some ions or molecules on the inhibition effectiveness of the extracts was also reported, ${ }^{\mathbf{1 6}, 17,71}$ meaning that the corrosion inhibition performance is higher for the mixture than for the individual components alone. AlTurkustani et al. ${ }^{\mathbf{1 6}}$ added $\mathrm{NaI}$ to the aqueous extract of Aloe vera leaves and then studied its inhibition effectiveness in the corrosion of $95.30 \%$ aluminium in $0.25-1.50 \mathrm{M} \mathrm{HCl}$ solution at $30{ }^{\circ} \mathrm{C}$. The results showed a further increase in the inhibition effectiveness of the extract when $0.01 \mathrm{M}$ NaI was added. However, when changing the iodide concentration from $1 \times$ $10^{-4}$ to $5 \times 10^{-2} \mathrm{M}$ in the presence of $48 \mathrm{vol} \%$ aloe leaf extract, first an increase in the inhibition effectiveness was observed (up to $2.5 \times 10^{-2} \mathrm{M}$ ) and then for higher iodide concentrations the inhibition effectiveness decreased. In addition to the well- 
known iodide ions, it was reported that metals can also influence the performance of the tested extracts. In fact, Rajendran et $a .^{71}$ tested the aqueous extract of Hibiscus rosa-sinensis flowers, with and without the addition of $\mathrm{Zn}^{2+}$, as a corrosion inhibitor for $95 \%$ aluminium in $\mathrm{NaOH}$ solution of $\mathrm{pH}=12$. In the presence of $50 \mathrm{ppm}$ of $\mathrm{Zn}^{2+}$, the authors reported an improvement in the inhibition effectiveness. However, the data showed that this is not the case for low volumes of extract added ( 2 and $4 \mathrm{~mL}$ added). Moreover, the addition of $25 \mathrm{ppm}$ of $\mathrm{Zn}^{2+}$ dramatically decreased the inhibition effectiveness (promoting corrosion). The authors explained this with the possible precipitation of the complex formed between $\mathrm{Zn}^{2+}$ and the active principle present in the extract. The performance of the system $8 \mathrm{~mL}$ of extract $+50 \mathrm{ppm}$ of $\mathrm{Zn}^{2+}$ was also tested with the addition of sodium dodecyl sulphate (SDS) and $N$-cetyl $-N, N, N$ trimethylammonium bromide (CTAB) after 1 day of immersion. It was reported that the inhibition effectiveness decreased and reached a minimum (for $150 \mathrm{ppm}$ SDS added) and then increased again in the case of SDS. The authors reported that the inhibition effectiveness first increased with the increase in the CTAB concentration (up to $200 \mathrm{ppm}$ ) and then decreased. Abdel-Abdel-Gaber et al. $^{\mathbf{1 7}}$ studied the synergistic effect of cetyl trimethyl ammonium bromide and the aqueous extract of lupine seed as an inhibitor in the corrosion of $99.68 \%$ aluminium in $2 \mathrm{M} \mathrm{NaOH}$ solution. The authors reported that there is no significant synergistic effect between the lupine seed extract and cetyl trimethyl ammonium bromide. The authors reported that $\mathrm{CTAB}$ was used to alter the wettability, acting as a foaming agent as well as reducing the surface tension to ensure the stability of the lupine seed extract.

The influence of temperature on the inhibition effectiveness of aqueous extracts was studied from 20 to $70{ }^{\circ} \mathrm{C} .{ }^{64-69,73,75,76,80}$ Singh et $a .^{66}$ prepared extracts of Bacopa monnieri stem and evaluated the inhibition effectiveness of the extract in the corrosion of AA1060 aluminium alloy in $0.5 \mathrm{M} \mathrm{NaOH}$ solution at $35-55^{\circ} \mathrm{C}$. The authors reported that the inhibition effectiveness of the extract decreased with increasing temperature. Geetha et $a l .{ }^{67}$ reached the same conclusion when studying the inhibition effectiveness of the aqueous extract of Solanum trilobatum leaves as a corrosion inhibitor in the corrosion of aluminium in $1 \mathrm{M} \mathrm{NaOH}$ solution at $30-60{ }^{\circ} \mathrm{C}$. A decrease in the inhibition effectiveness with increasing temperature was reported in the case of aqueous extract of Piper longum seeds tested as an inhibitor in the corrosion of AA1060 aluminium alloy in $1 \mathrm{M}$ $\mathrm{NaOH}$ solution, ${ }^{73}$ as well for the aqueous extract of Neolamarkia cadamba bark as a corrosion inhibitor for $98.06 \%$ aluminium alloy in $1 \mathrm{M} \mathrm{NaOH}$ solution at $30-60{ }^{\circ} \mathrm{C} .{ }^{64}$ The same influence of temperature on the inhibition effectiveness of the extracts was also reported by Sirajunnisa et al. ${ }^{65}$ Geetha et al. ${ }^{68}$ and Al-HajAli et $a l .{ }^{75}$ The opposite behaviour, i.e. an increase in inhibition effectiveness with increasing temperature, was reported for aqueous extracts of Garcinia indica seed, ${ }^{76}$ Vigna unguiculata husk, ${ }^{69}$ and olive seeds. ${ }^{80}$

Polarisation measurements were conducted in several studies and the authors reported on the inhibitor types of the respective extracts. In the vast majority, the extracts acted as mixed-type inhibitors. Singh and Quraishi ${ }^{70}$ investigated the inhibition effectiveness of Trachyspermum copticum seed extract in double-distilled water as a corrosion inhibitor for AA1060 aluminium alloy in $0.5 \mathrm{M} \mathrm{NaOH}$ solution at $35{ }^{\circ} \mathrm{C}$. PDP measurements showed that the extract acted as a mixed-type inhibitor. The same was reported by Sirajunnisa et $a .^{65}$ regarding the aqueous extract of Senna auriculata leaves tested as a corrosion inhibitor for aluminium with purity higher than $99.9 \%$ in $1 \mathrm{~N} \mathrm{NaOH}$ solution at $30-60{ }^{\circ} \mathrm{C}$. Other extracts acted also as mixed-type inhibitors. ${ }^{16,17,64,66,67,72,73,76,79}$ Geetha et al. ${ }^{68}$ found that the aqueous extract of Vitex negundo leaves acted as a mixed-type inhibitor, but with a predominant effect on the anodic reaction in the corrosion of aluminium in $1 \mathrm{M} \mathrm{NaOH}$ solution at $30-60{ }^{\circ} \mathrm{C}$. The aqueous extracts of saffron leaves were found to act as a cathodic-type inhibitor. ${ }^{74}$ The same was reported by Fetouh et al. $^{77}$ for the aqueous extracts of Ambrosia maritima L., Lupinus sp. L, and Cymbopogon proximus. However, as mentioned above, Abd-El-Nabey et al. $^{79}$ reported that the aqueous extract of damsissa (Ambrosia maritima L.) acted as a mixed-type inhibitor. Moreover, Gerengi ${ }^{78}$ reported that the aqueous extract of Phoenix dactylifera fruit juice acted as a weak cathodic-type inhibitor in the corrosion of AA7075 aluminium alloy in $3.5 \% \mathrm{NaCl}$ solution.

Based on the change of inhibition effectiveness with the temperature described above, as well as on the thermodynamic calculations, several authors discussed the possible mechanism for their respective extracts. Geetha et al. ${ }^{68}$ suggested that the aqueous extract of Vitex negundo leaves physisorbed on the aluminium surface immersed in $1 \mathrm{M} \mathrm{NaOH}$ solution at 30$60{ }^{\circ} \mathrm{C}$. Next, Al-Haj-Ali et al. ${ }^{75}$ suggested that phytochemical compounds contained in the aqueous extract of date palm (Phoenix dactylifera) leaves are responsible for the physisorption of the extract on $98.8 \%$ aluminium surface immersed in $1 \mathrm{M}$ $\mathrm{HCl}$ solution, at $20-50{ }^{\circ} \mathrm{C}$. Physisorption was suggested as the mechanism responsible for the adsorption of other extracts on the surface of aluminium materials. ${ }^{16,65,67,75,78}$

The aqueous extract of olive (Olea europaea) seeds was reported to chemisorb on $98.63 \%$ aluminium alloy in $1 \mathrm{M} \mathrm{HCl}$ solution at $30{ }^{\circ} \mathrm{C}^{80}$ It was reported by Prabhu and $\mathrm{Rao}^{76}$ that garcinol, isogarcinol, and curcumin are the main active components of the aqueous extract of Garcinia indica seeds. ${ }^{76}$ The authors suggested that the extract physisorbed on the surface of $99.61 \%$ aluminium immersed in $0.5 \mathrm{M} \mathrm{H}_{3} \mathrm{PO}_{4}$ solution at $30-50{ }^{\circ} \mathrm{C}$. The same mechanism was also suggested for aqueous extracts of Vigna unguiculata husk. ${ }^{69}$ A mixed-type (physisorption and chemisorption) adsorption mechanism was suggested by Fetouh et al. ${ }^{77}$ The authors concluded that the extracts initially physisorbed on the aluminium surface and then chemisorption occurred through coordinate bond formation between the p-valence orbitals of the aluminium and the oxygen and nitrogen atoms or $\mathrm{OH}$ groups present in the structure of the main components of these extracts.

The inhibitive action of the studied aqueous extracts has been attributed in general to the formation of a protective monolayer on the aluminium/solution interface. ${ }^{\mathbf{6 4 , 6 6 , 7 1 , 7 3 , 7 4 , 7 6}}$ According to Prabhu and Rao, ${ }^{76}$ this layer is formed on the aluminium surface as a result of chelate complex formation with aluminium ions, which then precipitates on the areas 
where the oxide film is destroyed. Complex formation was also reported for the aqueous extract of Hibiscus rosa-sinensis flowers. ${ }^{71}$ Soror $^{74}$ suggested that the inhibition action of the aqueous extract of saffron leaves is due to the formation of a compact barrier film though adsorption on the metal surface, displacing the water molecules. Moreover, they suggested the formation of a coordinative covalent bond between the lone pair electrons present in the oxygen atoms of the inhibitor molecule and the metal.

Abd-El-Nabey et al. ${ }^{79}$ concluded that the anodic dissolution of aluminium is controlled by the diffusion of $\mathrm{AlO}_{2}{ }^{-}$from the surface of the metal to bulk solution. The authors studied the effect of the aqueous extracts of damsissa and Corchours itorius on the corrosion of $99.687 \%$ aluminium in $0.1 \mathrm{M} \mathrm{Na}_{2} \mathrm{CO}_{3}$ solution. They reported that the main components in the damsissa extract are ambrosin, damsin, and coumarin, while for Corchours itorius extract the main components are beta carotene, and vitamins A, B-1, B-2, C, and E.

Chaubey et al., ${ }^{64} \mathrm{Al}$-Turkustani and Emran $^{80}$ and Emran et $a{ }^{63}{ }^{63}$ reported efficient extraction of inhibitive compounds under moderate conditions with water as the solvent of choice. This technique enables efficient extraction of inhibitive compounds under moderate conditions. Further purification is performed simply by filtering the obtained extract to obtain a homogenous solution. As mentioned above, high temperatures are a serious drawback of the conventional procedures, due to possible degradation of thermally unstable compounds. The loss of some components and the degradation of some unsaturated compounds by thermal effects or by hydrolysis can be generated by these conventional extraction techniques. Sirajunnisa et al. ${ }^{65}$ reported high temperatures during sample preparation and subsequent heating of the filtrates in a water bath to fully evaporate the moisture content to obtain the dried compound, which may affect the inhibiting action of Senna auriculata leaf extract. Umoren et $a l^{\mathbf{8 1}}$ discussed that compounds are subjected to degradation or undergo undesirable oxidation by exposure to high processing temperature.

\subsection{The corrosion inhibition of plant extracts obtained with solvents used as a corrosive environment}

The plant extracts tested in the research works described below were prepared using the same solvents as the corrosive environment in which the aluminium materials were immersed. The work of Berkovic et al. ${ }^{82}$ included an additional step in the extract preparation procedure. The authors first dissolved rutin and quercetin in $\mathrm{NaOH}$ solution, from which a solution of each in $3 \% \mathrm{NaCl}$ was prepared. These solutions were then tested as inhibitors in the corrosion of $99.95 \%$ aluminium in $3 \% \mathrm{NaCl}$ solution. Apart from this study, ${ }^{82}$ all other research work was published on the inhibition of aluminium materials in alkaline $(\mathrm{NaOH} \text { and } \mathrm{KOH})^{83-96}$ and acidic $\left(\mathrm{HCl} \text { and } \mathrm{H}_{2} \mathrm{SO}_{4}\right)^{9-11,85,93,97-107}$ solutions (Table 3 ).

Two research groups investigated the influence of the corrosive environment on the inhibition effectiveness of the respective extracts. ${ }^{85,93}$ Oguzie et al. ${ }^{85}$ tested the extract of Gongronema latifolium leaves in $\mathrm{HCl}$ and $\mathrm{KOH}$ as a corrosion inhibitor for AA1060 aluminium alloy in $2 \mathrm{M} \mathrm{HCl}$ and $2 \mathrm{M} \mathrm{KOH}$ solutions at 30 and $60{ }^{\circ} \mathrm{C}$. The authors reported that the inhibition effectiveness of Gongronema latifolium leaves in $\mathrm{HCl}$ was higher than Gongronema latifolium leaves in $\mathrm{KOH}$. The extract of Euphorbia hirta leaves in $\mathrm{HCl}$ and $\mathrm{NaOH}$ was tested as an inhibitor in the corrosion of AA3003 aluminium alloy in $0.5 \mathrm{M}$ $\mathrm{HCl}$ and $0.25 \mathrm{M} \mathrm{NaOH}$ solutions at 30 and $60{ }^{\circ} \mathrm{C} .{ }^{93}$ The alkaline extract was reported to be more effective. The alkaline extract of Euphorbia hirta leaves was also reported as a corrosion inhibitor for AA3003 aluminium alloy in $0.25 \mathrm{M} \mathrm{NaOH}$ solution at 30 and $60{ }^{\circ} \mathrm{C}$, in addition to Dialum guineense leaf extract in $\mathrm{NaOH} .{ }^{87}$

In two studies Loto et al. ${ }^{\mathbf{1 0 6 , 1 0 7}}$ tested the inhibition effectiveness of Camellia sinensis leaf extracts in $\mathrm{HCl}$ and $\mathrm{H}_{2} \mathrm{SO}_{4}$ as a corrosion inhibitor for $99 \%$ aluminium alloy in $0.5 \mathrm{M} \mathrm{HCl}$ solution and $0.8 \mathrm{M} \mathrm{H}_{2} \mathrm{SO}_{4}$ solution, respectively. The inhibition effectiveness increased with increasing extract concentration and with increasing exposure time in the $\mathrm{HCl}$ solution. The authors reported a decrease in the inhibition effectiveness with increasing extract concentration in $\mathrm{H}_{2} \mathrm{SO}_{4}$ solution.

The inhibition effectiveness increased with increasing extract concentration, with the exception of Euphorbia hirta leaf extracts in $\mathrm{HCl}$ and $\mathrm{NaOH}^{93}$ and Camellia sinensis leaf extract in $\mathrm{H}_{2} \mathrm{SO}_{4},{ }^{107}$ mentioned above. Loto et al. ${ }^{107}$ reported a decrease in inhibition effectiveness with increasing concentration of the extract, while no significant change was reported by Nnanna et $a l .{ }^{93}$

The possible synergistic effect of potassium iodide and thiocyanate with the tested extracts was also explored. Obot and Obi-Egbedi ${ }^{9}$ added $5 \mathrm{mM}$ KI to the extract of ginseng (Panax ginseng) root in $\mathrm{HCl}$ used as a corrosion inhibitor for AA1060 aluminium alloy at $30-60{ }^{\circ} \mathrm{C}$. A further increase in the inhibition effectiveness was observed with the addition of $\mathrm{KI}$ and was more pronounced at higher temperatures. A synergistic increase in the inhibition effectiveness of Thymus algeriensis leaf and seed extracts in $\mathrm{HCl}$ extract was reported upon the addition of KI. ${ }^{\mathbf{1 1}}$ The mixture was tested as a corrosion inhibitor for AA2024 aluminium alloy in $1 \mathrm{M} \mathrm{HCl}$ solution at $25-65{ }^{\circ} \mathrm{C}$. The inhibition effectiveness of Ipomoea invulcrata leaf extract in $\mathrm{HCl}$, tested as a corrosion inhibitor for AA1060 aluminium alloy (98.8\% purity) in $1 \mathrm{M} \mathrm{HCl}$ solution at $30-60{ }^{\circ} \mathrm{C}$ was further increased with the addition of $\mathrm{KI}^{10}$ The authors reported that KSCN showed an antagonistic effect when added to the extract at high temperatures.

The corrosion inhibition of numerous aluminium materials

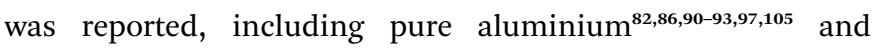
$1 \times x x,{ }^{9,10,85,94,99,103} 2 x x x,{ }^{11,102} 3 x x x,{ }^{87,88}$ and $8 x^{2} x^{98,100,104}$ series aluminium alloys. The corrosion of 3SR aluminium alloy $(98.60 \% \mathrm{Al})$ in $2 \mathrm{M} \mathrm{NaOH}$ solution was investigated in the presence of Gossypium hirsutum L. leaf and seed extracts in $\mathrm{NaOH}^{83}$ and Phyllanthus amarus leaf extract. ${ }^{84}$ Other aluminium alloys were also tested. ${ }^{106,107}$ Leaves, ${ }^{10,11,83-85,87-89,91,93,97-104,106,107}$ seeds, ${ }^{11,86,102}$ peel, ${ }^{90}$ root, ${ }^{9}$ and petals ${ }^{105}$ were the parts of the plants from which extracts were prepared. Extracts in $\mathrm{HCl}$ of Mentha pulegium ${ }^{\mathbf{1 0 2}}$ and Thymus algeriensis ${ }^{\mathbf{1 1}}$ were prepared from the aerial parts (leaves and seeds) of the respective plants.

Abiola et $a l .{ }^{83}$ investigated the influence of the plant part on the inhibition effectiveness of the extract. Gossypium hirsutum L. 


\section{西}

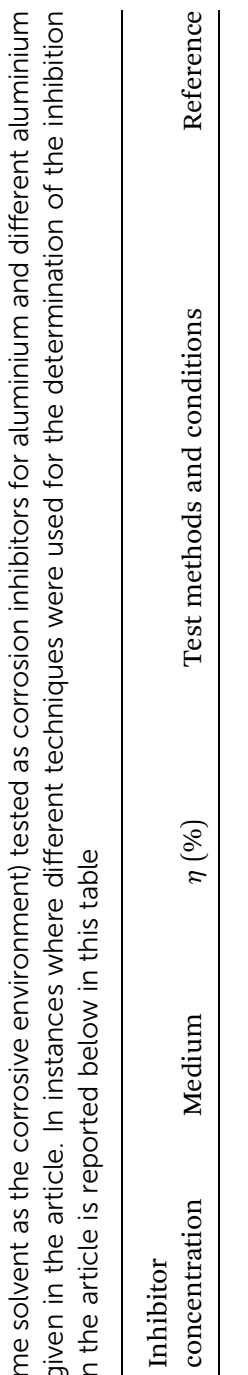

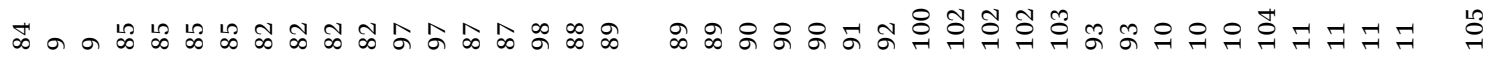

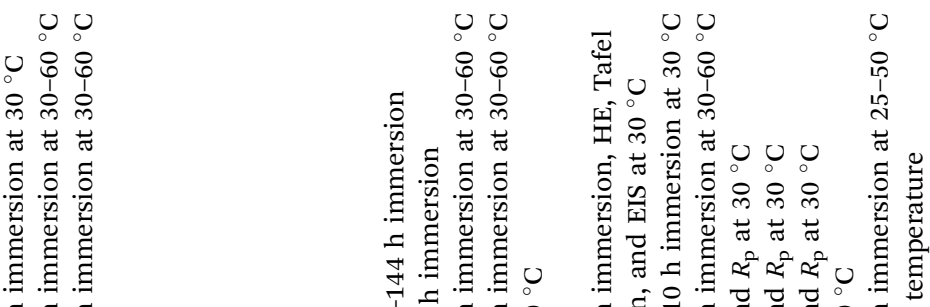

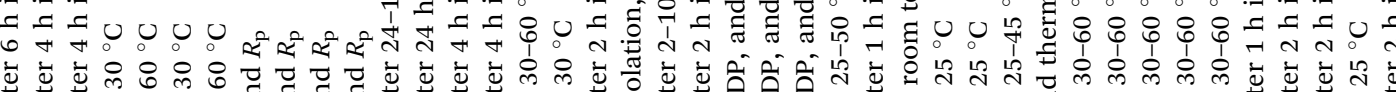

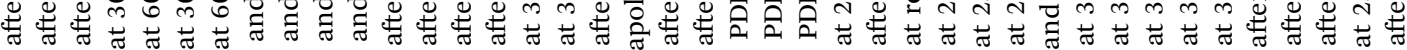

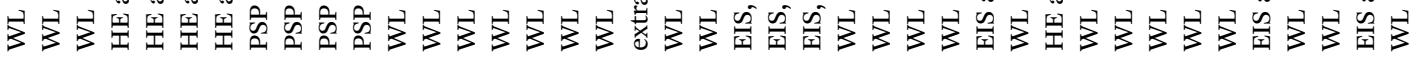

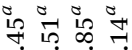

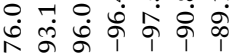

等

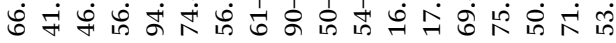

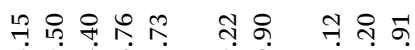

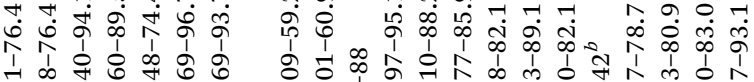

तिல்

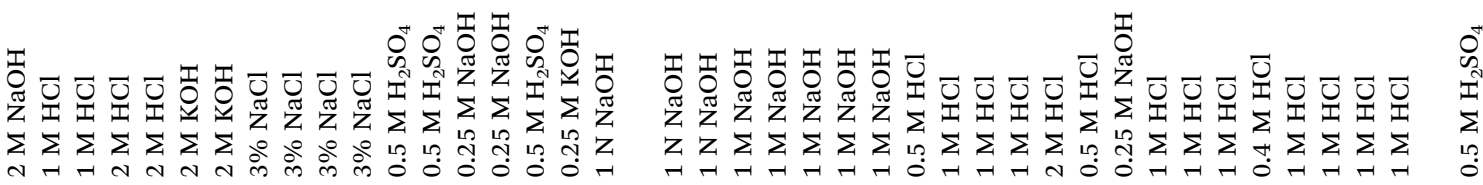

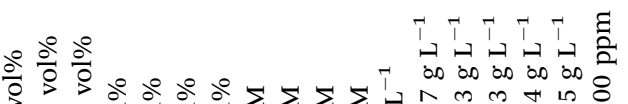

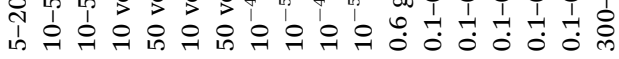

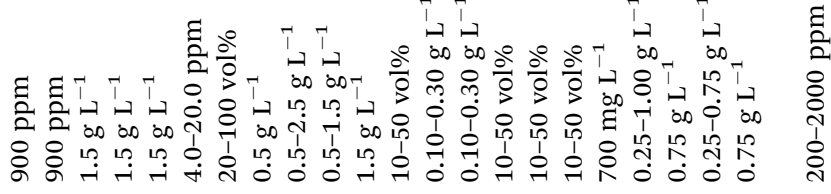

क.

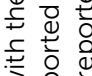

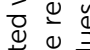

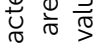

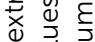

至

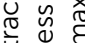

×

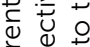

竞

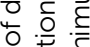

约

ข $\cong$

总导

过

음

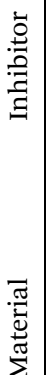
1
0
0

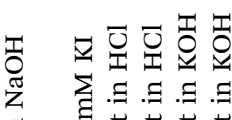

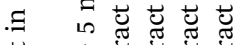

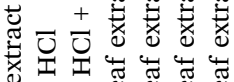

ब.

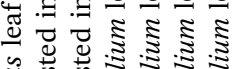

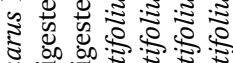

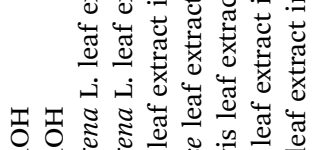

㻤.

๖े

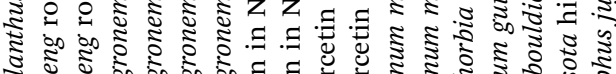

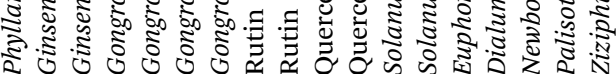

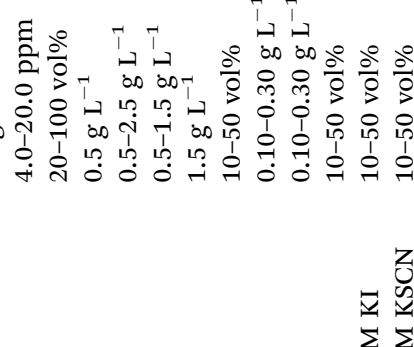

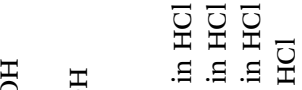

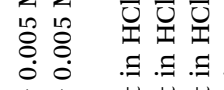

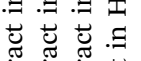

$++\quad+\quad \exists . \Xi$

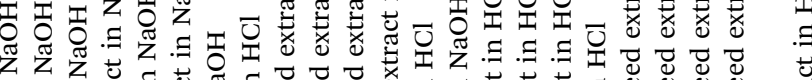

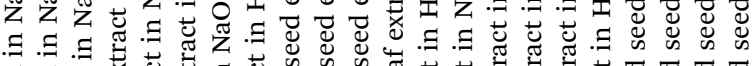

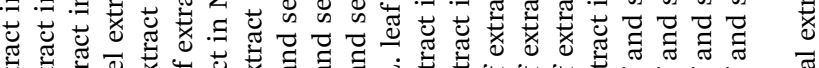

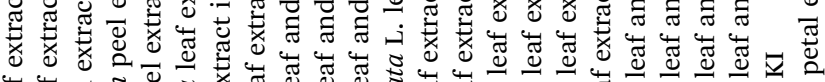

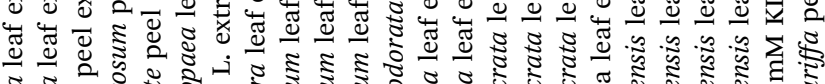

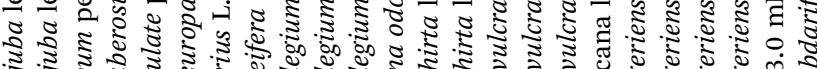

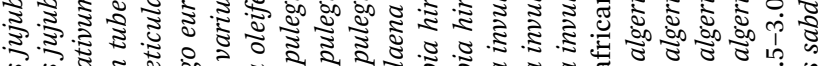

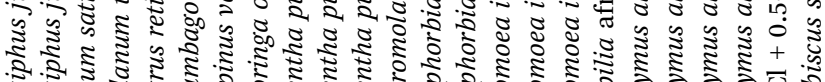

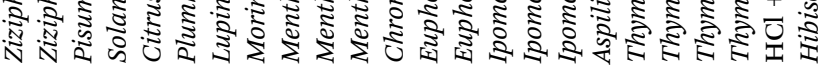


leaf and seed extracts, prepared by using the reflux in $\mathrm{NaOH}$ solution, was tested in the corrosion of 3SR aluminium alloy (98.60\% aluminium) in $2 \mathrm{M} \mathrm{NaOH}$ solution. The authors reported that the seed extract was slightly more effective than the leaf extract.

This group of extracts was tested at temperatures varying from 25 to $60{ }^{\circ} \mathrm{C}^{9-11,87,89,91-93,95,96,98,100,102-105}$ The inhibition effectiveness of the majority of the extracts decreased with increasing temperature. Nnanna et al. ${ }^{87}$ investigated the extracts of Euphorbia hirta and Dialum guineense leaves in $\mathrm{NaOH}$ as corrosion inhibitors of AA3003 aluminium alloy in $0.25 \mathrm{M}$ $\mathrm{NaOH}$ solution at 30 and $60{ }^{\circ} \mathrm{C}$. The major constituents of Euphorbia hirta were reported to be triterpenoids, alkaloids, tannins, glycosides, sterols, essential oil, flavones, and phenols. Dialum guineense contains mainly saponins, tannins, alkaloids, flavonoids, and essential oil. The authors reported that the inhibition effectiveness decreased with increasing temperature for both extracts. The same conclusion was reported for Euphorbia hirta leaf extract in $\mathrm{NaOH}$ in another study by Nnanna et al. ${ }^{93}$ It was found by Sirajunnisa et al. ${ }^{89}$ that the inhibition effectiveness of Ziziphus jujuba leaf extract in $\mathrm{NaOH}$, tested as an inhibitor in the corrosion of aluminium in $1 \mathrm{~N}$ $\mathrm{NaOH}$ solution, decreased with increasing temperature. Irshedat et al..$^{92}$ reported that the inhibition effectiveness of Lupinus varius $\mathrm{L}$. extract in $\mathrm{NaOH}$ as a corrosion inhibitor for $99.96 \%$ aluminium in $1 \mathrm{M} \mathrm{NaOH}$ solution at $25-50{ }^{\circ} \mathrm{C}$ decreased with increasing temperature. A decrease in the inhibition effectiveness with increasing temperature was also reported by Nnanna et al. ${ }^{98}$ for Newbouldia leavis leaf extract in $\mathrm{H}_{2} \mathrm{SO}_{4}$, tested as an inhibitor in the corrosion of AA8011 aluminium alloy in $0.5 \mathrm{M}$ $\mathrm{H}_{2} \mathrm{SO}_{4}$ solution at 30 and $60{ }^{\circ} \mathrm{C}$. The same behaviour was reported by Khadraoui et al. ${ }^{102}$ regarding the inhibition effectiveness of Mentha pulegium leaf and seed extract in $\mathrm{HCl}$ used as a corrosion inhibitor for AA2024 aluminium alloy in $1 \mathrm{M} \mathrm{HCl}$ solution at $25-45{ }^{\circ} \mathrm{C}$. Obot and Obi-Egbedi ${ }^{103}$ reported a decrease in the inhibition effectiveness of Chromolaena odorata $\mathrm{L}$. leaf extract in $\mathrm{HCl}$, tested as a corrosion inhibitor for AA1060 aluminium alloy in $2 \mathrm{M} \mathrm{HCl}$ solution, when increasing the temperature from 30 to $60{ }^{\circ} \mathrm{C}$. Chaubey et al. ${ }^{96}$ Obot and Obi-Egbedi, ${ }^{9}$ Nnanna and Owate,,$^{100}$ Obot et al., ${ }^{10}$ and MolinaOcampo et al. ${ }^{105}$ reached the same conclusion regarding the influence of temperature on the inhibition effectiveness of the respective extracts. Different behaviour was reported by Bataineh $e t$ al., ${ }^{91}$ who concluded that the inhibition effectiveness of Plumbago europaea leaf extract in $\mathrm{NaOH}$ used as an inhibitor in the corrosion of $99.96 \%$ aluminium in $1 \mathrm{M} \mathrm{NaOH}$ solution at 20-50 ${ }^{\circ} \mathrm{C}$ increased with increasing temperature. Similarly, Mejeha et al. ${ }^{104}$ concluded that the inhibition effectiveness of Aspilia africana leaf extract in $\mathrm{HCl}$ tested as a corrosion inhibitor for AA3003 aluminium alloy in $0.4 \mathrm{M}$ and $0.5 \mathrm{M} \mathrm{HCl} \mathrm{solu-}$ tions at 30 and $60{ }^{\circ} \mathrm{C}$, increased with increasing temperature. A slight increase in the inhibition effectiveness with increasing temperature was reported by Bataineh et al. ${ }^{95}$ for Sinapis alba dry powder extract refluxed in $\mathrm{NaOH}$ tested as a corrosion inhibitor for $99.999 \%$ aluminium in $1 \mathrm{M} \mathrm{NaOH}$ solution at $25-$ $50{ }^{\circ} \mathrm{C}$. Only Khadraoui et al. ${ }^{11}$ reported no significant change in 
inhibition effectiveness with increasing temperature for Thymus algeriensis leaf and seed extract in $\mathrm{HCl}$.

Polarisation measurements have been performed in a few studies and the inhibitor type for the respective extracts has been reported..$^{89,90,95,104,105}$ Chaubey et al. ${ }^{90}$ studied the inhibition effectiveness of Pisum sativum, Solanum tuberosum, and Citrus reticulate peel extracts in $\mathrm{NaOH}$ in the corrosion of $99.76 \%$ aluminium alloy in $1 \mathrm{M} \mathrm{NaOH}$ solution at $30^{\circ} \mathrm{C}$. The inhibition effectiveness of the extracts decreased in the order Pisum sativum > Solanum tuberosum > Citrus reticulate. PDP measurements showed that all three extracts acted as mixed-type inhibitors. Hibiscus sabdariffa petal extract in $\mathrm{H}_{2} \mathrm{SO}_{4}$ was reported to act as a mixed-type inhibitor in the corrosion of pure aluminium in $0.5 \mathrm{M} \mathrm{H}_{2} \mathrm{SO}_{4}$ solution at $25-60{ }^{\circ} \mathrm{C} .{ }^{105}$ Moreover, it was reported that the extracts of Ziziphus jujuba leaves in $\mathrm{NaOH},{ }^{89}$ Sinapis alba dry powder in $\mathrm{NaOH},{ }^{95}$ as well as stem bark extracts in $\mathrm{NaOH}$ of Moringa oleifera, Terminalia arjuna, and Mangifera indica ${ }^{96}$ also acted as mixed-type inhibitors. PDP measurements showed that Aspilia africana leaf extract in $\mathrm{HCl}$ acted as a cathodic-type inhibitor. ${ }^{\mathbf{1 0 4}}$

Based on the thermodynamic calculations, authors have suggested the adsorption mechanism of the studied extracts. ${ }^{9,10,85-89,91-95,97-107}$ Nwosu and Osarolube ${ }^{86}$ studied the extract of Xylopia aethiopica seeds in $\mathrm{KOH}$ as a corrosion inhibitor for $98.47 \%$ aluminium in $0.75 \mathrm{M} \mathrm{KOH}$ solution at room temperature. The authors reported that the optimal inhibition effectiveness was $84.53 \%$, but this is not supported by the results presented. According to the authors, the extract protected aluminium by physisorption on its surface. Similarly, Mejeha et al. ${ }^{97}$ suggested physisorption as the possible mechanism for the adsorption of Solanum melongena L. leaf extract in $\mathrm{H}_{2} \mathrm{SO}_{4}$, tested as an inhibitor in the corrosion of AA1060 aluminium alloy in $0.5 \mathrm{M} \mathrm{H}_{2} \mathrm{SO}_{4}$ solution. Physisorption was also suggested for other extracts as the possible mechanism for their adsorption on the surface of the aluminium materials. ${ }^{9,10,89,91-95,98,100,103,105-107}$ Chemisorption was suggested by Oluseyi et al. ${ }^{99}$ as the possible adsorption mechanism for Vernonia amygdalina leaf extract in $\mathrm{HCl}$ on the AA1100 aluminium alloy surface, immersed in $0.5 \mathrm{M} \mathrm{HCl}$ solution at $40{ }^{\circ} \mathrm{C}$. Omotosho and Ajayi ${ }^{101}$ investigated the inhibition effectiveness of Vernonia amygdalina leaf extract in $\mathrm{HCl}$ as a corrosion inhibitor for $99 \%$ aluminium alloy in $2 \mathrm{M} \mathrm{HCl}$ solution. Based on the thermodynamic calculations, the authors suggested chemisorption as the possible adsorption mechanism for Vernonia amygdalina extract on the aluminium alloy surface. The same adsorption mechanism was suggested for Mentha pulegium leaf and seed extract in $\mathrm{HCl}^{102}$ The studies of Oguzie et al..$^{85}$ and Mejeha et $a l .{ }^{104}$ reported an influence of either the corrosive environment or temperature on the adsorption mechanism of the tested extracts. Oguzie et al. ${ }^{85}$ based on the variation of the inhibition effectiveness with temperature, suggested chemisorption in the case of Gongronema latifolium leaf extract in $\mathrm{HCl}$ tested in $2 \mathrm{M} \mathrm{HCl}$ solution and physisorption in the case of $2 \mathrm{M}$ $\mathrm{KOH}$ solution. However, they reported on the possibility of chemisorption in $2 \mathrm{M} \mathrm{KOH}$ at higher extract concentrations. Mejeha et al. ${ }^{104}$ reported the presence of three B vitamins, i.e. thiamine, riboflavin, and niacin, in Aspilia africana leaf extract in $\mathrm{HCl}$, which are responsible for its inhibition action. The authors suggested physisorption at low temperatures and chemisorption at high temperatures. Finally, Nnanna et al. ${ }^{88}$ tested the extract of Palisota hirsute leaves in $\mathrm{KOH}$ as an inhibitor in the corrosion of AA3003 aluminium alloy in $0.25 \mathrm{M}$ $\mathrm{KOH}$ solution at $30^{\circ} \mathrm{C}$. Thermodynamic calculations suggested that the adsorption of the extract was of a mixed nature (physisorption and chemisorption). A mixed adsorption mechanism was also suggested for Euphorbia hirta leaf extract in $\mathrm{NaOH}^{.87}$

The authors attribute the inhibition action of these extracts to the ability of their components to adsorb on the surface of the aluminium materials. However, in the best of cases they mention only the class of compounds responsible for the adsorption and very rarely are the compounds identified. Irshedat et al. ${ }^{92}$ attributed the inhibition action of Lupinus varius $\mathrm{L}$. extract in $\mathrm{NaOH}$ to its phytochemical constituents (alkaloids, tannins, oligosaccharides, polysaccharides, glucoproteins, volatile monoterpenes, and related oxygenated sesquiterpenes) that contain oxygen and nitrogen atoms, serving as adsorption centres. Ipomoea invulcrata leaf extract in $\mathrm{HCl}^{10}$ and in $\mathrm{NaOH}^{94}$ adsorbed due to the presence of the heteroatoms and aromatic rings with $\pi$-bonds in the molecule of the main constituent, which serve as adsorption centres. The authors reported that the main constituent of this plant is Dlysergic acid amide and also it contains small amounts of other alkaloids, such as chanoclavine, elymoclavine, ergometrine, and D-isolysergic acid amide.

The presence of certain groups or a particular bonding of these components with the surface of aluminium materials was also reported. Nnanna and Owate ${ }^{\mathbf{1 0 0}}$ evaluated the inhibition effectiveness of the leaf extract of Moringa oleifera in $\mathrm{HCl}$, as a corrosion inhibitor for AA8011 aluminium alloy in $0.5 \mathrm{M} \mathrm{HCl}$ solution at 30 and $60{ }^{\circ} \mathrm{C}$. The authors attributed the inhibition action of the extract to the presence of the $\mathrm{C}=\mathrm{O}$ functional group. Omotosho and Ajayi ${ }^{\mathbf{1 0 1}}$ attributed the inhibition action of Vernonia amygdalina leaf extract in $\mathrm{HCl}$ to the formation of a covalent bond between the phytochemical constituents of the extract and the aluminium alloy. Molina-Ocampo et al. ${ }^{\mathbf{1 0 5}}$ attributed the inhibition action of Hibiscus sabdariffa petal extract in $\mathrm{H}_{2} \mathrm{SO}_{4}$ to adsorption on the aluminium surface through the lone pairs and p-orbitals of the heteroatoms present in the structure of the flavonoid compounds present in the extract.

In addition, a few authors reported a protective layer (film) formation as the result of adsorption. ${ }^{\mathbf{8 2 , 9 5 , 9 6 , 1 0 0}}$ This protective layer in the case of stem bark extracts in $\mathrm{NaOH}$ of Moringa oleifera, Terminalia arjuna, and Mangifera indica ${ }^{96}$ was formed through the adsorption of their main components, 4-(alpha- $l$ rhamnopyranosyloxy)-benzylglucosinolate, ellagic acid, and mangiferin, respectively. Berkovic et al. ${ }^{82}$ reported that the protective layer (film) formed by the adsorption of rutin and quercetin was stable at lower concentrations $\left(10^{-4}\right.$ and $\left.10^{-5} \mathrm{M}\right)$, while at higher concentrations (higher $\mathrm{pH}$ ) the film dissolved due to the amphoteric nature of aluminium, promoting corrosion.

The majority of the authors reported quick and simple extraction procedures to obtain extracts with a high inhibitive 
effect. A simple extraction procedure was utilised in the work of Abiola et $a .^{84}$ to isolate these compounds from the plant of Phyllanthus amarus. The authors reported that Phyllanthus amarus extract contains several phytochemicals, in particular two lignans, i.e. phyllathin and hypophyllathin, which contain several adsorption centres. These kind of extraction procedures are uncomplicated and require a significantly lower amount of organic solvents compared to other methods, a relatively short time for crude sample preparation, and above all, a high yield of the target compounds is reported as having been attained. These procedures may be applied to prepare a relatively large amount of extract using either a plant's stem, leaf, or root, which are otherwise usually discarded. Each step in the extraction procedure requires specific attention regarding the operating parameters and furthermore this increases operating costs and influences the duration of the process. Compared to previous isolation methods, which included multiple steps using various organic solvents with a time intensive separation process, ${ }^{108}$ the method reported by Obot and Obi-Egbedi ${ }^{9}$ is simple and found to produce a much higher yield of active compounds as compared to the method of Pyo et al. ${ }^{\mathbf{1 0 8}}$ The development of "modern" sample-preparation techniques with significant advantages over conventional methods for the extraction and analysis of plants is likely to play an important role in the overall effort to ensure and provide high-quality plant extracts. Khadraoui et al. ${ }^{102}$ reported that different methods were investigated for selectively preparing extracts of Mentha pulegium leaves and seeds and the extracts were subsequently evaluated to compare the efficiency of the SFE with the hydrodistillation process. In comparison to the hydrodistillation method, SFE yields a lower number of constituents of interest. The authors assume that all of these components are present in the $\mathrm{SC}-\mathrm{CO}_{2}$ extracts, but at lower concentration than those obtained by hydrodistillation. ${ }^{109}$ Modern extraction techniques feature mild operating conditions, resulting in a higher concentration of active compounds present in the extract. Nnanna et $a{ }^{93}$ highlights that it may be safely assumed that lower extraction temperatures would yield a higher content of phytochemical components, which include tannins, alkaloids, and essential oil in the extract. The inhibitive properties of tannins have been attributed to the reaction of the polyphenolic fraction of tannin moieties by hindering both cathodic and anodic electrode processes due to the high number of bonds in the extracts.

\subsection{Corrosion inhibition of plant extracts obtained with mixed solvents}

Differences in the structure of phenolic compounds also determine their solubility in solvents of different polarity. Therefore, different solvent compositions may have a significant impact on their relative capacity to extract the total phenolic and total flavonoid components of a plant's leaves, trunk, and stems. There are some reports concerning the optimisation of the extraction conditions of the phenolic compound content and antioxidant activities of some plant foods, nevertheless, the optimal procedure is usually unique to different plant matrices. ${ }^{\mathbf{1 1 0 , 1 1 1}}$

In the following paragraphs we discuss studies published on the corrosion inhibition of aluminium and its alloys by plant extracts that are extracted by either several solvents of different types, ${ }^{112-114}$ or by a mixture of two solvents. ${ }^{115-117}$ As seen in Table 4 , an acetone/water $(1: 1)$ mixture was used to prepare extracts of red onion (Allium cepa L.) skin, ${ }^{115}$ breadfruit (Artocarpus altilis) peel, ${ }^{\mathbf{1 1 6}}$ and garlic (Allium sativum) skin, ${ }^{\mathbf{1 1 7}}$ which were then tested as corrosion inhibitors for $98.76 \%$ aluminium in $2 \mathrm{M} \mathrm{H}_{2} \mathrm{SO}_{4}$ solution at $30-50{ }^{\circ} \mathrm{C}$ (ref. 115) for commercial aluminium in $0.5 \mathrm{M} \mathrm{H}_{2} \mathrm{SO}_{4}$ solution ${ }^{116}$ and for $97.58 \%$ aluminium alloy in $0.5 \mathrm{M} \mathrm{HCl}$ solution, ${ }^{117}$ respectively. Ethanol, ethyl acetate, $\mathrm{HCl}$, and water were employed to extract different parts of various plants. Several studies reported on the possible influence of the solvent used on the inhibition effectiveness of the respective extract. Alinnor and Ejikeme ${ }^{112}$ used $\mathrm{HCl}$, ethanol, and distilled water to prepare extracts of Ocimum gratissimum leaves and tested the extracts as corrosion inhibitors for AA1060 aluminium alloy in $1 \mathrm{M} \mathrm{HCl}$ solution at 30 and $60^{\circ} \mathrm{C}$. The authors showed that the inhibition effectiveness followed the order extract in distilled water $>$ extract in ethanol $>$ extract in $\mathrm{HCl}$.

Abiola et al. ${ }^{113}$ prepared extracts of Delonix regia leaves and seeds in hydrochloric acid and ethanol and tested the extracts as inhibitors in the corrosion of $99.16 \%$ aluminium in $2 \mathrm{M} \mathrm{HCl}$ solution at $30{ }^{\circ} \mathrm{C}$. The authors concluded that the acid extracts were more effective than the ethanolic extracts.

Aqueous extract of Juglans regia L. leaves showed a higher inhibition effectiveness compared with ethyl acetate extract in protecting $99.8 \%$ aluminium immersed in $1 \mathrm{M} \mathrm{HCl}$ solution, at room temperature. ${ }^{\mathbf{1 1 4}}$ Several solvents (water, methanol, ethanol, and $50 \%$ aqueous solutions of methanol and ethanol) were utilised to prepare extracts from walnut green husk, placing a specific emphasis on the extraction yield and antioxidant properties of the compounds present in total extracts. The highest extraction yield was obtained with water, although aqueous extracts showed the lowest antioxidant properties. The highest total phenol content and antioxidant activities, measured by reducing power and diphenylpicrylhydrazyl assays, were obtained with $50 \%$ aqueous ethanol.

Leaves, ${ }^{112-114}$ seeds, ${ }^{113}$ skin, and peel ${ }^{115-117}$ were used to prepare the extracts. Abiola et al. ${ }^{113}$ found an influence of the plant part used to prepare the extract on the inhibition effectiveness of Delonix regia. The authors reported that the inhibition effectiveness followed the order acid seed extract $>$ acid leaf extract $>$ ethanol seed extract $>$ ethanol leaf extract.

All the extracts were tested in an acidic environment, mainly in $\mathrm{HCl}$ solution. In all these studies it was reported that inhibition effectiveness increased with increasing extract concentration. Pure aluminium and 1xxx series aluminium alloy were the only tested materials.

The inhibition effectiveness of these extracts has been investigated from room temperature up to $60{ }^{\circ} \mathrm{C} .{ }^{112,115,116}$ In all three studies the authors reported that the inhibition effectiveness decreased with increasing temperature. However, Alinnor and Ejikeme $^{\mathbf{1 1 2}}$ reported a significant decrease in 
政

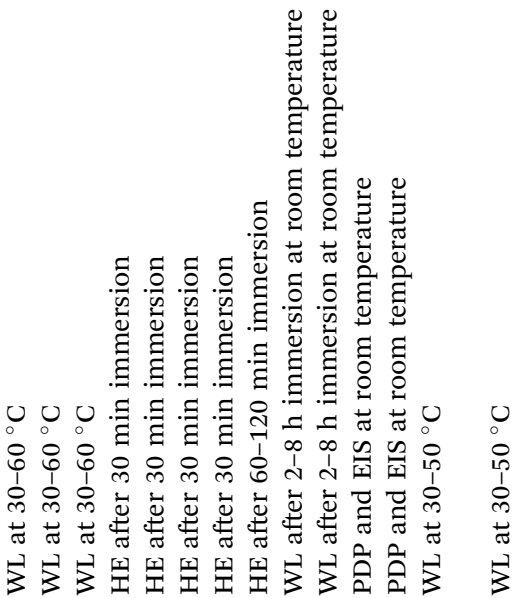

다유. இं बं

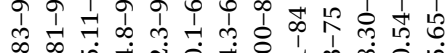
舟只

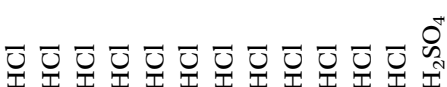

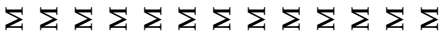

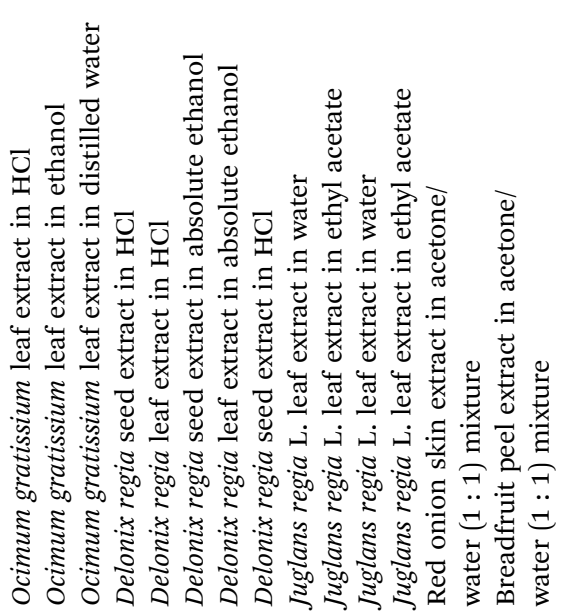

inhibition effectiveness with increasing temperature for Ocimum gratissimum leaf extracts in $\mathrm{HCl}$, ethanol, and distilled water, while only a slight decrease was observed when increasing the temperature for breadfruit (Artocarpus altilis) peel extract. ${ }^{116}$

The vast majority of the studies evaluated the inhibition effectiveness of the extracts using chemical techniques (WL and HE). Only Akin et al., ${ }^{114}$ based on the PDP measurements, concluded that Juglans regia L. leaf extracts in water and ethyl acetate reduced the anodic and cathodic currents of the corrosion couple.

Based on the thermodynamic calculations, the authors suggested physisorption as the possible mechanism for the adsorption of the respective extracts on the surface of aluminium materials. ${ }^{12,113,116,117}$ Red onion (Allium cepa L) skin extract in acetone/water $(1: 1 \mathrm{v} / \mathrm{v})$ mixture $^{115}$ was reported to physisorb through its main component, quercetin.

\section{Drugs as corrosion inhibitors for aluminium and its alloys}

As pointed out above, drugs were previously considered as corrosion inhibitors, especially in relation to the corrosion inhibition of steel. ${ }^{22}$ However, studies describing drugs as corrosion inhibitors for aluminium and its alloys are rather rare, although such research might become attractive in the near future. Fig. 3 summarises the structures of all the drugs reported as corrosion inhibitors herein. Until now, antibacterial and antifungal drugs were among the most studied compounds as corrosion inhibitors for aluminium and its alloys in various solutions. ${ }^{12,13,118-123}$ However, a few studies were also performed on the possible application of antihypertensive and antiemetic drugs as corrosion inhibitors. ${ }^{124,125}$ All the studied drugs were tested as corrosion inhibitors in acidic solutions.

The WL technique has been widely used to evaluate the inhibition performance of these compounds. Polarisation techniques were also employed in several of the included studies $^{12,118,123,124}$ and in all cases the authors concluded that the respective drugs used acted as mixed-type inhibitors. In all the research work published on the use of drugs as corrosion inhibitors it was reported that inhibition effectiveness increased proportionally with drug concentration, but decreased with increasing temperature. Based on the thermodynamic calculations, the authors suggested mainly physisorption as the possible adsorption mechanism for all the studied drugs, ${ }^{12,13,119,120,122,123}$ apart from the work of Bhat and Alva, ${ }^{124}$ who suggested a mixed-type adsorption (physisorption and chemisorption) for meclizine hydrochloride. However, these authors also reported the predominance of physisorption in the total mechanism.

Gece prepared a comprehensive review article relating drugs from different pharmacotherapeutic groups, that have completely different biologic mechanism of action, as corrosion inhibitors for various materials. ${ }^{22}$ However, it has to be taken into account that the pharmacodynamic, and hence the pharmacologic action the drugs cause to the body, has in its essence 

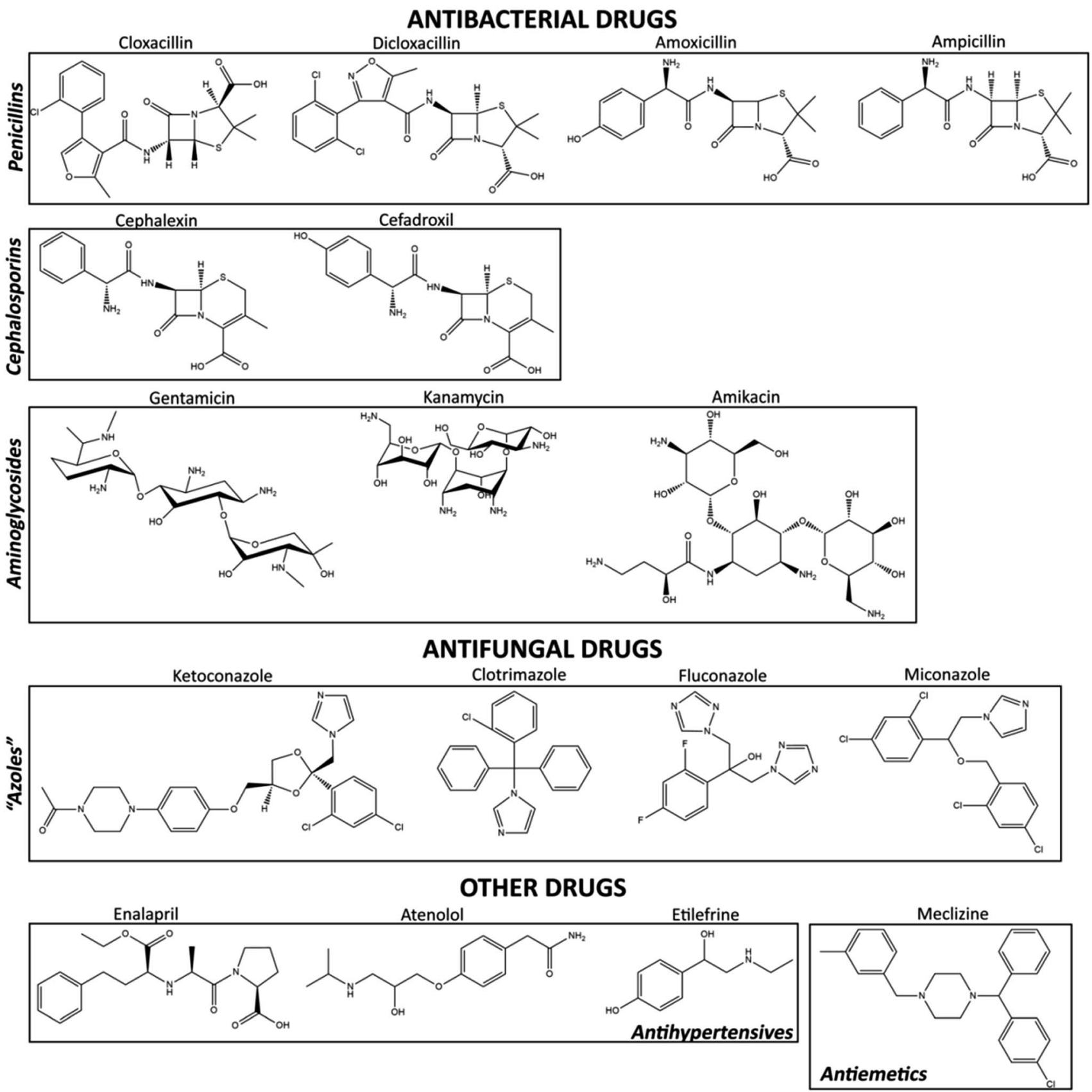

Fig. 3 Structures of the drugs tested.

nothing to do with the mechanism of their potential corrosion inhibition. Furthermore, these drug-based corrosion inhibition candidates can be better grouped together by general molecular features (like the presence of heterocycles in their structure, or reactive centres like $\mathrm{O}, \mathrm{N}$ and/or $\mathrm{S}$ atoms containing lone pairs of electrons, which can aid their adsorption onto metal surfaces), rather than by their biologic activity. Here we can again build on the conclusions by Gece, who found essentially the same, ${ }^{22}$ namely that the features related to the bare chemical structure (backbone) of these is far more important, than their features, giving them their potential to be used as drugs for various purposes. Nevertheless, reviewing (or grouping) drugs by their pharmacotherapeutic groups it is logical also in their description, related to their corrosion inhibition potential. Namely, by doing these, a researcher with a background related to biological sciences, can then easily search for their potential dual use in practice. This is especially true in relation to medical implants (e.g. metal based hip prostheses), where either antimicrobial drugs (like antifungals and antibiotics) or antiinflammatory drugs, can significantly contribute to both, the corrosion inhibition during their prolonged exposure to the harsh biologic environment of the body, while at the same time easing the uptake of the implant by the body, by either preventing infections or diminishing the possibility of an immune response that could even lead to the implants rejection. 
In each of the following paragraphs, we briefly describe the general use of these drugs in medical applications. The main findings (as described above) regarding the use of drugs as corrosion inhibitors for aluminium materials are presented in Table 5 , followed by a more detailed description of the work.

\subsection{Antibacterial drugs}

Antimicrobial agents are some of the most widely used therapeutic drugs worldwide. The terms antimicrobial, antibiotic, and anti-infective encompass a wide variety of pharmaceutical agents that include antibacterial, antifungal, antiviral, and antiparasitic drugs. Of these, antibacterial agents are by far the most commonly used and thus are a focus of this article, although similar principles apply to the agents from the other groups as well. ${ }^{126}$ The combination of antibacterial drugs and metals seems straightforward, since there are many applications of metals and alloys where antibacterial activity is desired. ${ }^{127-130}$

3.1.1 Penicillins. Penicillins are among the first effective antibacterial drugs used in modern medicine. ${ }^{131}$ The lead compound was of natural origin (derived from Penicillium fungi), and was subsequently modified to yield several novel semisynthetic drugs with different spectra of activity and effectiveness against a variety of bacterial infections. ${ }^{\mathbf{1 3 1}}$ Penicillins act by inhibiting the formation of cross-links in the bacterial cell wall, which weakens it to such an extent that the osmotic pressure in the interior of the bacteria becomes increasingly uncompensated, causing cell death. ${ }^{\mathbf{1 3 2}}$ Since their biological target is an enzyme involved in the bacterial cell wall synthesis, their corrosion inhibition activity is more likely related only to their base chemical structure, probably due to the heteroatoms present in their so called $\beta$-lactam heterocycle lead structure.

To the best of our knowledge, there are only two studies that evaluated the corrosion inhibition potential of penicillins for the protection of aluminium, ${ }^{\mathbf{1 2 , 1 3 3}}$ namely two $\beta$-lactamase resistant penicillins, i.e. cloxacillin and dicloxacillin, and two compounds from the so-called aminopenicillins group, i.e. amoxicillin and ampicillin, which are two of the most commonly used antibiotics at the moment (Fig. 3).

Abdallah $^{\mathbf{1 3 3}}$ reported on the use of four antibacterial drugs from the group of penicillins, i.e. ampicillin, cloxacillin, flucloxacilin, and amoxicillin as inhibitors in the corrosion of $99.99 \%$ aluminium in $2 \mathrm{M} \mathrm{HCl}$ solution. The authors attributed the increase in the inhibition effectiveness of these compounds to the increase in the electron donor characteristics of the substituted groups, following the order amoxicillin $>$ ampicillin $>$ cloxacillin $>$ flucloxacillin.

3.1.2 Cephalosporins. Cephalosporins were discovered in the middle of the last century as extracts from the fungus Cephalosporium acremonium. ${ }^{\mathbf{1 3 4}}$ With a similar spectrum of activity against bacteria as penicillins, they are often the second line of treatment, when penicillins cannot be used or when their often low solubility in aqueous media is not a limitation. Since they possess a structure similar to penicillins, they are also prone to degradation by $\beta$-lactamase, a common bacterial strategy to gain resistance to antibacterial drugs. ${ }^{132}$ Similar to penicillins, their corrosion inhibition potential lies most likely in the possible delocalization of $\pi$ electrons, which can enhance their adsorption to metal surfaces. ${ }^{22}$

Fouda et al. ${ }^{12}$ investigated the use of five antibacterial compounds from the group of penicillins, i.e. flucloxacillin (also known by the name floxacillin), dicloxacillin, cloxacillin, and cephalosporins of the first-generation, i.e. cephalexin, and cefadroxil, as inhibitors in the corrosion of AA6063 aluminium alloy in $0.5 \mathrm{M} \mathrm{H}_{3} \mathrm{PO}_{4}$ solution at $30{ }^{\circ} \mathrm{C}$. The authors reported that cloxacillin and cefadroxil performed better compared to the other compounds in the penicillin and first-generation cephalosporins groups. A further increase in inhibition effectiveness was reported upon the addition of KI.

3.1.3 Aminoglycosides. Aminoglycosides are antibacterial drugs that inhibit bacterial protein synthesis by binding specifically to the bacterial $30 \mathrm{~S}$ ribosomal subunit, causing a misreading of mRNA and leaving the bacterium unable to synthesise proteins important for growth. ${ }^{\mathbf{1 3 5}}$ Their name originates from the amino-modified glycoside in their structure. The drugs used in ref. 118 include gentamicin and kanamycin (mostly referred to as kanamycin A), which belong to the deoxystreptamin-containing aminogylocides, and amikacin, which is usually used as a last-resort medication against multidrug-resistant bacteria. Although the main structure of the aminoglycosides is not based on the $\beta$-lactam ring structure, some similarity with the above described antibiotics can be seen. Some aminoglycosides also include heterocycles in their structures. These are single saccharide O-containing monomers, which can work as binding centers in a similar manner as the above mentioned antibiotics.

Abdallah and Jahdaly ${ }^{118}$ evaluated the inhibition effectiveness of three antibacterial drugs from the group of aminoglycosides, i.e. gentamicin, kanamycin, and amikacin as corrosion inhibitors for $99.99 \%$ aluminium in $1 \mathrm{M} \mathrm{HCl}$ solution at $30{ }^{\circ} \mathrm{C}$. The inhibition effectiveness followed the order amikacin $>$ kanamycin $>$ gentamicin. The authors attributed this order to the change in molecular weight and the number of heteroatoms present in these compounds. According to the authors, these drugs adsorbed on the aluminium surface through the oxygen atoms in the heterocyclic rings as well as the amino groups. Coordination bonds might be formed between the unshared electron pairs of the oxygen and nitrogen atoms and the empty p-orbitals of aluminium.

\subsection{Antifungals}

Drugs for systemic antifungal treatment (some are also used for the treatment of topical infections) include amphotericin $\mathrm{B}$ (and its lipid formulations), various azole derivatives, echinocandins, and flucytosine. ${ }^{\mathbf{1 3 6}}$ In the following articles, antifungal drugs from the subgroup of "azoles" (a commonly used term in medicine for this type of antifungal, which all exhibit the same mechanism of action, regardless of the type of non-carbon atoms in the heterocycle), were the only ones applied. The respective drugs from this group of antifungals inhibit the fungal enzyme called lanosterol $14 \alpha$-demethylase, which converts lanosterol to ergosterol. ${ }^{137}$ Ergosterol is an important 


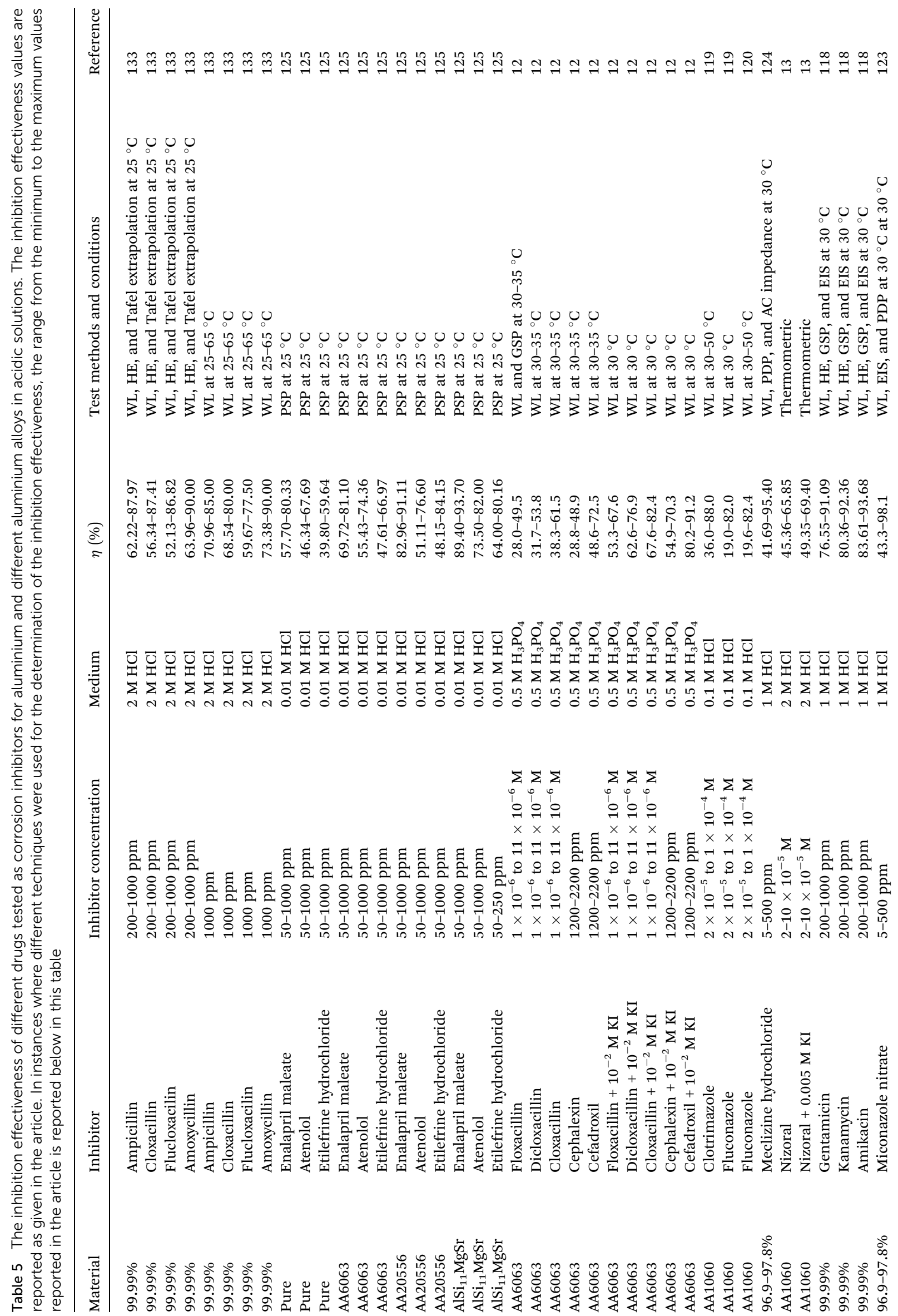


component of the fungal membrane and its depletion leads to the disruption of the membrane structure (e.g. nutrient transport, fluidity, etc.), which results in the inhibition of fungal growth. ${ }^{138}$ Studies investigating the use of antifungals as corrosion inhibitors report the use of two different type of azoles, namely the imidazoles (clotrimazole, ketoconazole, and miconazole) and the newer triazole (fluconazole). The azole type compounds, in a chemical sense, are well known as effective corrosion inhibitors for different metallic materials in various corrosive solutions. ${ }^{6,8,139-141}$

Since the main target of these drugs is again an enzyme involved in the synthesis of an essential microbe structural element, it seems that the biologic and corrosion inhibitions activities are not related. Nevertheless, it has to be stated, that the target enzyme in the case of the below mentioned antifungals, is an iron including protein. This could point to a potential relation between their biologic and corrosion inhibitions activities. Further studies are necessary to see if the actual drug target site (and hence the molecule orientation) has any correlation with its alignment and adsorption to the metal surface. Furthermore, the enzyme contains iron, which raises the question if a similar consideration can be also used in the case of aluminium.

Obot et al. ${ }^{119}$ evaluated the performance of two antifungal drugs, i.e. clotrimazole and fluconazole, as corrosion inhibitors for AA1060 aluminium alloy in $0.1 \mathrm{M} \mathrm{HCl}$ at 30 and $50{ }^{\circ} \mathrm{C}$. Clotrimazole was more effective than fluconazole in protecting the aluminium alloy in $0.1 \mathrm{M} \mathrm{HCl}$ solution. The authors attributed this behaviour to the fact that clotrimazole has the highest HOMO energy ( $E$ (HOMO)) and the lowest difference of $E($ LUMO) - E(HOMO). In a previous publication, Obot and ObiEgbedi $^{\mathbf{1 2 0}}$ reported that the adsorption of fluconazole was mainly due to an increase in the adsorption enthalpy rather than a reduction in the adsorption entropy. Fluconazole can adsorb not only as a cationic species on the aluminium alloy surface, but it can also adsorb as a molecular species using oxygen, nitrogen, and benzylic carbons as its active centres. The same conclusion is also presented by Obot et al. ${ }^{121}$ Obot et al. ${ }^{122}$ reported that the inhibition action of clotrimazole on the corrosion of $98.8 \%$ aluminium under the same conditions $\left(0.1 \mathrm{M} \mathrm{HCl}\right.$ solution at 30 and $\left.50{ }^{\circ} \mathrm{C}\right)$ is due to physisorption through the active centres found mainly in the imidazole ring.

Bhat and Alva ${ }^{\mathbf{1 2 3}}$ evaluated the inhibition effectiveness of miconazole nitrate as a corrosion inhibitor for 96.9-97.8\% aluminium in $1 \mathrm{M} \mathrm{HCl}$ solution at $30{ }^{\circ} \mathrm{C}$. The authors reported that this drug is protonated in acid solutions, probably at the nitrogen atoms of the imidazole ring, forming in this way a cationic inhibitor species.

Obot and Obi-Egbedi ${ }^{\mathbf{1 3}}$ studied the inhibition effectiveness of the antifungal drug nizoral (ketoconazole) as a corrosion inhibitor for AA1060 aluminium alloy in $2 \mathrm{M} \mathrm{HCl}$ solution. A further increase in inhibition effectiveness was reported upon the addition of KI.

\subsection{Other drugs}

There are two additional studies reporting the use of other drugs as corrosion inhibitors for aluminium. ${ }^{\mathbf{1 2 4 , 1 2 5}}$ In the first study, ${ }^{125}$ three drugs acting on the cardiovascular system were employed. They belong to the group of antihypertensive drugs, which are among the most prescribed group of drugs in the world. The antihypertensive drugs used in the work of Abdallah et al. ${ }^{125}$ come from different pharmacodynamic groups (they act on different physiological processes in the body). Namely, enalapril inhibits the angiotensin converting enzyme, while atenolol is a selective $\beta_{1}$ receptor antagonist (this subgroup of antihypertensive drugs is commonly referred to as $\beta$-blockers). The third drug used in ${ }^{\mathbf{1 2 5}}$ is an antihypotensive (working in the opposite manner as the first two drugs), and is clinically used in the treatment of orthostatic hypotension regardless of the origin thereof.

The main "heterocycle/heteroatom" theory can be partially used in the case of enalapril and meclizine, which both include $\mathrm{N}$-containg heterocycles in their structures. In the case of atenolol and etilefrine this is not the case, nevertheless, also both of these drugs include functional groups, capable of $\pi$ electron delocalization (aromatic ring in etilefrine; the aromatic ring and the amide group in atenolol), which may be responsible for the adsorption.

In terms of corrosion research, Abdallah et al. ${ }^{125}$ concluded that three drugs acting on the cardiovascular system i.e. enalapril maleate, atenolol, and etilefrine hydrochloride, act as inhibitors of the general and pitting corrosion of pure aluminium and three aluminium alloys, i.e. AA6063, AA20556, and $\mathrm{AlSi}_{11} \mathrm{MgBr}$ in $0.01 \mathrm{M} \mathrm{HCl}$ solution at $25{ }^{\circ} \mathrm{C}$. The authors reported that pure aluminium was less susceptible to corrosion compared to the three alloys. The inhibition effectiveness of the drugs increased with their concentration up to $250 \mathrm{ppm}$. At higher concentration values the inhibition effectiveness decreased and the authors attributed that to a steric hindrance effect. However, in the case of AA20556 alloy, when higher than 250 ppm of etilefrine hydrochloride was added, the inhibition effectiveness first decreased and then increased again. The authors attributed the inhibitive action of these drugs to the formation of insoluble complex adsorbed on the metal surface.

In the second article, Ishwara Bhat and $\mathrm{Alva}^{124}$ reported on the use of antiemetic drugs as corrosion inhibitors. The authors studied the inhibition effectiveness of meclizine hydrochloride as a corrosion inhibitor for 96.9-97.8\% aluminium alloy in $1 \mathrm{M}$ $\mathrm{HCl}$ solution at $30-60{ }^{\circ} \mathrm{C}$.

\section{Gums as corrosion inhibitors}

Plant-derived gums consist of a mixture of long-chain polysaccharide compounds, which are formed either naturally as a result of the disintegration of plant tissue (gummosis), injury to the bark or stem, or due to microbial attack (fungi and bacteria). ${ }^{\mathbf{1 4 2}}$ In general, they do not dissolve in oils and organic solvents. However, in contact with water, some of the gums are easily soluble, while others either adsorb water and swell up or disperse in water, giving a viscous solution or jelly. When hydrolised, these gums give simple monosaccharides (galactose, mannose arabinose) and glucuronic acid. ${ }^{26,142}$ The majority of gums are obtained from the stem, and only a few of 
them from other parts (roots, leaves, seeds) of plants mainly from the Leguminosae and Sterculiaceae families.

Apart from their well-known applications in the pharmaceutical ${ }^{142-144}$ and food industries, ${ }^{145,146}$ gums are used as corrosion inhibitors for different metals in various corrosive environments. ${ }^{26}$ These gums contain polysaccharide compounds rich in nitrogen and oxygen atoms, which serve as adsorption centres and therefore can act as corrosion inhibitors. Furthermore, gum-metal complexes are formed that act as a barrier layer and isolate the metal surface from the corrosive environment. ${ }^{26}$ In addition, gums have low toxicity, are biodegradable, and environmentally friendly. Several gums have been tested as corrosion inhibitors for aluminium and its alloys in various solutions. ${ }^{\mathbf{1 4 , 1 5 , 1 4 7 - 1 5 7}}$ Xanthan, Commiphora pedunculata, and arabic gums were used without further purification. ${ }^{15,147,149,155,156}$ Two different methods $^{158,159}$ were used to purify the other gums in the above studies. Purification of the gums through dissolution in $95 \%$ ethanol ${ }^{158}$ was employed for Raphia hookeri, ${ }^{\mathbf{1 4}}$ Pachylobus edulis ${ }^{\mathbf{1 4 8}}$ and Dacroydes edulis. ${ }^{\mathbf{1 5 4}}$ Eddy et al. ${ }^{159}$ purified the gum by first dissolving it in cold distilled water and then the solution was centrifuged, forming a dense gel. The supernatant was acidified to acidic $\mathrm{pH}$ with diluted hydrochloric acid. Then, 80\% ethanol was slowly added and the precipitated gum was obtained by centrifugation. Finally, the gum was washed with alcohol, followed by ether, and then dried before use. The same procedure was employed by Eddy et al. ${ }^{150,152,153,157}$ and Ameh $^{151}$ to purify the gums used in their respective studies.

The main findings (as described above) regarding the use of gums as corrosion inhibitors for aluminium materials are presented in Table 6 . In all these studies only classical techniques (WL, HE, and thermometric) were employed to evaluate the inhibition effectiveness of the tested gums (no electrochemical analysis was reported). Pure aluminium ${ }^{\mathbf{1 4 7 , 1 5 0 - 1 5 3}}$ and $1 \mathrm{xxx}$ series aluminium alloy ${ }^{\mathbf{1 5 , 1 4 8 , 1 5 4 - 1 5 6}}$ are among the most tested materials. It was reported in all studies that the inhibition effectiveness of the studied gums increased with increasing concentration. An increase in temperature resulted in an increase in the inhibition effectiveness in the studies of Arukalam et al., ${ }^{147}$ Ameh, ${ }^{151}$ Eddy et al., ${ }^{150,157}$ Umoren et al. ${ }^{15}$ and Umoren, ${ }^{155}$ while the opposite was observed in other studies. ${ }^{\mathbf{1 4 , 1 4 8 , 1 4 9 , 1 5 3 , 1 5 4 , 1 5 6}}$ A more irregular trend in the change in inhibition effectiveness with increasing temperature was reported by Eddy et $a .^{\mathbf{1 5 2}}$ for Ficus tricopoda gum. The authors reported a decrease in the inhibition effectiveness with an increase in temperature for concentrations up to $0.3 \mathrm{~g} \mathrm{~L}^{-1}$ gum added, while for higher gum concentrations the inhibition effectiveness increased with increasing temperature.

Arukalam et al. ${ }^{\mathbf{1 4 7}}$ reported on the inhibition effectiveness of xanthan gum in the corrosion of $98.08 \%$ aluminium alloy in $0.5 \mathrm{M} \mathrm{HCl}$ solution at $28-60{ }^{\circ} \mathrm{C}$. The authors concluded that the inhibition process is due to the ability of the protonated and molecular species to adsorb on the cathodic and anodic sites of the corroding metal surface.

Umoren and Ebenso ${ }^{\mathbf{1 4}}$ tested Raphia hookeri exudate gum as a corrosion inhibitor for aluminium (no composition given) in $0.1 \mathrm{M}$ and $2 \mathrm{M} \mathrm{HCl}$ solutions at $30-60{ }^{\circ} \mathrm{C}$ and suggested that it is effective. The authors described that Raphia hookeri exudate gum consists of D-mannopyranose and D-galactopyranose joined together. A further increase in the inhibition effectiveness was reported by the authors upon the addition of potassium halides ( $\mathrm{KI}, \mathrm{KCl}$, and $\mathrm{KBr}$ ). The synergistic effect of the halides was found to decrease in the order $\mathrm{I}^{-}>\mathrm{Br}^{-}>\mathrm{Cl}^{-}$. The authors attributed the order to the influence of the radii and electronegativity of the halide ions on the adsorption process. In another study, Umoren et al. ${ }^{\mathbf{1 4 8}}$ compared the inhibition effectiveness of Raphia hookeri and Pachylobus edulis exudate gums in the corrosion of AA1060 aluminium alloy (98.5\% purity) in $0.1 \mathrm{M}$ and $2 \mathrm{M} \mathrm{HCl}$ solutions at $30-60{ }^{\circ} \mathrm{C}$. The results showed that Raphia hookeri is a better inhibitor than Pachylobus edulis.

Umoren et $a l .{ }^{15}$ reported on the inhibition effectiveness of gum arabic as a corrosion inhibitor for AA1060 aluminium alloy in $1 \mathrm{M}$ and $2 \mathrm{M} \mathrm{NaOH}$ solutions at 30 and $40{ }^{\circ} \mathrm{C}$. The authors attributed the inhibition ability of this gum to the adsorption on the aluminium alloy surface of the main constituents, i.e. oligosaccharides, polysaccharides, glucoproteins, and arabinoglactan. Umoren ${ }^{\mathbf{1 5 5}}$ investigated the inhibition effectiveness of gum arabic as a corrosion inhibitor for the same aluminium alloy and temperatures in lower concentrations of $\mathrm{NaOH}$ (i.e. $0.1 \mathrm{M} \mathrm{NaOH}$ ) solutions. The same trend in the change of inhibition effectiveness with gum concentration and temperature compared to the previous work ${ }^{\mathbf{1 5}}$ was reported by the author. The inhibition effectiveness of gum arabic increased further upon the addition of 0.5 M KI. Gum arabic was also tested by Umoren $^{\mathbf{1 5 6}}$ as a corrosion inhibitor for the same aluminium alloy immersed in $0.1 \mathrm{M} \mathrm{H}_{2} \mathrm{SO}_{4}$ solution at $30-60{ }^{\circ} \mathrm{C}$. The inhibition effectiveness decreased with increasing temperature, contrary to what was reported regarding alkaline solutions. ${ }^{15,155}$

Ameh and Eddy ${ }^{149}$ studied the inhibition effectiveness of Commiphora pedunculata exudate gum as a corrosion inhibitor for AA3001 aluminium alloy in $0.1 \mathrm{M} \mathrm{HCl}$ solution at 30 and $60{ }^{\circ} \mathrm{C}$. Next, Ameh ${ }^{151}$ evaluated the inhibition effectiveness of Commiphora kestingii gum exudate as a corrosion inhibitor for $96.65 \%$ aluminium alloy in $0.1 \mathrm{M} \mathrm{H}_{2} \mathrm{SO}_{4}$ solution at 30 and $60{ }^{\circ} \mathrm{C}$. The author reported that this gum contained a significant amount of sucrose, octadecanoic acid, alpha camphorenal, nerolidolisobutyrate, diisopropenyl-1-methyl-1-vinyl cyclohexane, and abetic acid. Based on the change in inhibition effectiveness with temperature, the authors suggested chemisorption as the possible adsorption mechanism for Commiphora kestingii gum exudate. The same mechanism was previously suggested by Umoren et $a{ }^{15}$ for the adsorption of gum arabic on AA1060 aluminium alloy surface in $\mathrm{NaOH}$ solution.

Eddy et al. ${ }^{152}$ studied the inhibition effectiveness of Ficus tricopoda gum as a corrosion inhibitor for $96.65 \%$ aluminium alloy in $0.1 \mathrm{M} \mathrm{H}_{2} \mathrm{SO}_{4}$ solution at 30 and $60{ }^{\circ} \mathrm{C}$. Camphene, sucrose, 2-methylene cholestan-3-ol, and 7-hexadecenal are among the constituents of this gum, as reported by the authors. The authors reported that the adsorption of the Ficus tricopoda gum was endothermic up to $0.3 \mathrm{~g} \mathrm{~L}^{-1}$, but exothermic for higher gum concentrations. Next, the same group ${ }^{153}$ investigated the inhibition effectiveness of Ficus thonningii gum as a corrosion 


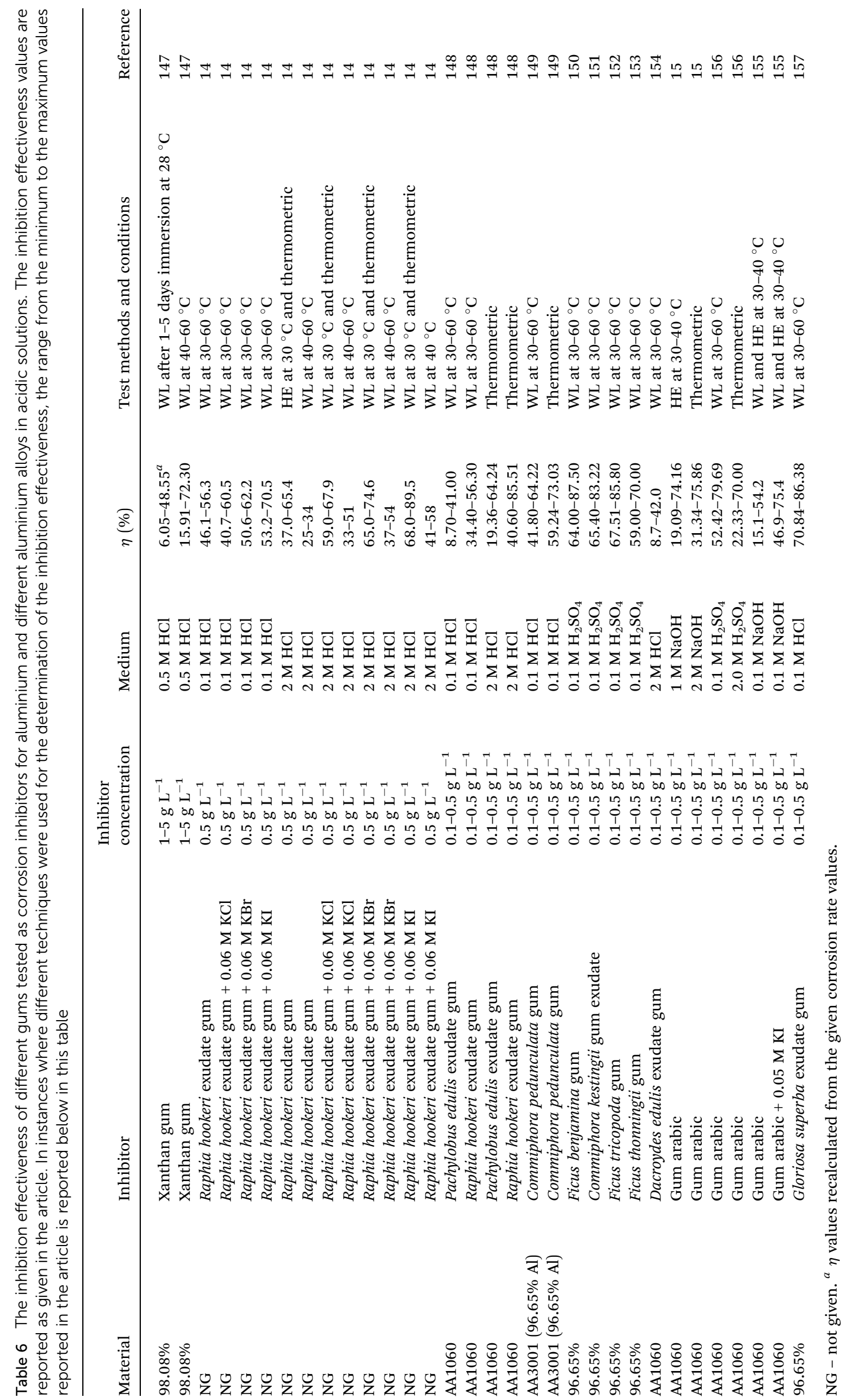


inhibitor for $96.65 \%$ aluminium alloy in $0.1 \mathrm{M} \mathrm{H}_{2} \mathrm{SO}_{4}$ solution at 30 and $60{ }^{\circ} \mathrm{C}$. Gas chromatography-mass spectrometry (GCMS) measurements showed that 16-methyl-octadecanoic acid, abietic acid, $n$-hexadecanoic acid, and andrographolide are among the main constituents of this gum. Finally, Eddy et al. ${ }^{\mathbf{1 5 0}}$ investigated the inhibition effectiveness of Ficus benjamina gum as a corrosion inhibitor for $96.65 \%$ aluminium alloy in $0.1 \mathrm{M}$ $\mathrm{H}_{2} \mathrm{SO}_{4}$ solution at 30 and $60{ }^{\circ} \mathrm{C}$. The authors reported that sucrose and D-glucose are the major constituents of the gum, while several carboxylic acids (including hexadecanoic acid, octadedecanoic acid, and 6,13-pentacenequinone) are present in smaller amounts. According to the authors, the inhibition action of Ficus benjamina gum is due to multiple-layer adsorption through its various components. Multiple-layer adsorption of the gum components was also proposed as the mechanism responsible for their inhibitive properties in the case of Commiphora kestingii gum by $\mathrm{Ameh}^{\mathbf{1 5 1}}$ and for gum arabic by Umoren. ${ }^{155}$

Umoren et al. ${ }^{154}$ studied the inhibition effectiveness of Dacroydes edulis exudate gum as a corrosion inhibitor for AA1060 aluminium alloy in $2 \mathrm{M} \mathrm{HCl}$ solution at $30-60{ }^{\circ} \mathrm{C}$. Although based on the thermodynamic calculations the authors suggested physisorption as the possible mechanism for this gum, no specific indication of which of the gum components adsorbed on the aluminium surface was given. The same mechanism (physisorption) was also suggested for Raphia hookeri gum, ${ }^{\mathbf{1 4 , 1 4 8}}$ Pachylobus edulis gum, ${ }^{\mathbf{1 4 8}}$ Commiphora pedunculata gum, ${ }^{\mathbf{1 4 9}}$ Ficus benjamina gum ${ }^{\mathbf{1 5 0}}$ Ficus thonningii gum, ${ }^{\mathbf{1 5 3}}$ and gum arabic in acidic solution. ${ }^{\mathbf{1 5 6}}$

Eddy et $a l .{ }^{157}$ reported on the inhibition effectiveness of Gloriosa superba exudate gum $(\mathrm{pH} \approx 2)$ as a corrosion inhibitor for $96.65 \%$ aluminium alloy in $0.1 \mathrm{M} \mathrm{HCl}$ solution at 30 and $60{ }^{\circ} \mathrm{C}$. GC-MS revealed that the main constituents of the Gloriosa superba gum are 1-piperoylp, 1-penta-decarborxylic acid, 9octadecenoic acid, and stigmasta-5,22-dien-3-ol. Quantum chemical studies showed that the adsorption of this gum is due to the presence of the amide group in stigmasta-5,22-dien-3-ol and of the hydroxyl group in 1-piperoylp. Based on the thermodynamic calculations, the authors suggested a mixed-type (physisorption and chemisorption) mechanism for the adsorption of Gloriosa superba gum on the aluminium surface. A mixed-type adsorption mechanism was also proposed for Ficus tricopoda gum $^{\mathbf{1 5 2}}$ and for gum arabic on AA1060 aluminium alloy in $\mathrm{NaOH}$ solutions. ${ }^{155}$

\section{Natural oils as corrosion inhibitors}

Essential oils, commonly known as volatile or ethereal oils, are concentrated hydrophobic liquids containing monoterpene and sesquiterpene hydrocarbons and oxygenated compounds (alcohols, aldehydes, ketones, acids, phenols, oxides, lactones, ethers, and esters), which are responsible for the characteristic odours and flavours. Due to the fact that most flowers do not contain enough volatile oil to undergo expression and their chemical components are too delicate and easily denatured by the high heat used in steam distillation, a solvent such as hexane or $\mathrm{SC}-\mathrm{CO}_{2}$ is used to extract the oils from the crude plant material. Since safer and less harmful solvents that are easy to remove or recover are gaining in popularity, the extraction of essential oil components using SFE has received much attention, particularly in the food, pharmaceutical, and cosmetic industries, as a sustainable alternative to conventional processes such as organic solvent extraction and steam distillation. ${ }^{62}$

The presence of the above-mentioned components combined with their low toxicity and high availability make essential oils suitable for use as corrosion inhibitors for different metals in various environments. ${ }^{\mathbf{1 6 0 - 1 6 3}}$ However, only a limited number of oils have been tested as corrosion inhibitors for aluminium and its alloys. ${ }^{\text {164-171 }}$ The majority of the studies have been carried out in acidic solutions. Fayomi and Popoola $^{\mathbf{1 6 6}}$ reported on the inhibition effectiveness of green roasted Elaeis guineensis oil in the corrosion of AA6063 aluminium alloy in $3.5 \% \mathrm{NaCl}$ solution, while Lavandula angustifolia $\mathrm{L}$. and Laurus nobilis L. oils inhibited the corrosion of aluminium and AA5754 aluminium alloy, respectively, in 3\% $\mathrm{NaCl}$ solutions. ${ }^{169,170}$ Pure aluminium and the 5xxx and $6 \mathrm{xxx}$ series aluminium alloys were the tested materials. The main findings (as described above) regarding the use of natural oils as corrosion inhibitors for aluminium materials are presented in Table 7. As for the other natural compounds, the inhibition effectiveness increased with increasing concentration of all the studied oils.

Halambek et al. ${ }^{167}$ Halambek and Berković, ${ }^{168}$ and Halambek et al. ${ }^{170}$ investigated the influence of temperature on the inhibition effectiveness of three oils dissolved in $30 \mathrm{vol} \%$ ethanol. Halambek et al. ${ }^{\mathbf{1 6 7}}$ reported on the inhibition effectiveness of Ocimum basilicum L. essential oil as a corrosion inhibitor for $99.85 \%$ aluminium in $0.5 \mathrm{M} \mathrm{HCl}$ solution at 30$85{ }^{\circ} \mathrm{C}$. The upper temperature employed certainly contributes to the degradation of polyphenols, especially during exposure for a long time. Therefore, lower temperatures would be desired. However, degradation does not occur immediately, therefore a shorter exposure time may not be so harmful. The authors reported that linalool is the main component of the oil, followed by smaller amounts of eugenol, 1,8-cineole, and geraniol. Halambek and Berković ${ }^{168}$ investigated the inhibition effectiveness of Anethum graveolens L. oil as a corrosion inhibitor for $99.85 \%$ aluminium in $1 \mathrm{M} \mathrm{HCl}$ solution at $25-75{ }^{\circ} \mathrm{C}$ (this upper temperature limit might also contribute to the degradation of these compounds, as discussed above). The authors reported that the main components of the oil are carvone and limonene. Halambek et al. ${ }^{\mathbf{1 7 0}}$ studied the inhibition effectiveness of Lavandula angustifolia $\mathrm{L}$. oil as a corrosion inhibitor for $\mathrm{Al}-3 \mathrm{Mg}$ $(95.5 \% \mathrm{Al})$ in $3 \% \mathrm{NaCl}$ solution at $25-60{ }^{\circ} \mathrm{C}$. The authors reported that linalool and linalyl acetate are the main components of Lavandula angustifolia L. oil. In all three studies the authors reported that the inhibition effectiveness of the respective oils decreased with increasing temperature, which might be connected with decomposition. Halambek et al. ${ }^{\mathbf{1 7 0}}$ attributed this behaviour to the desorption of the inhibitor molecules with increasing temperature.

The influence of the corrosive environment on the inhibition effectiveness of two oils was studied by Popoola et al. ${ }^{\mathbf{1 6 4}}$ and 


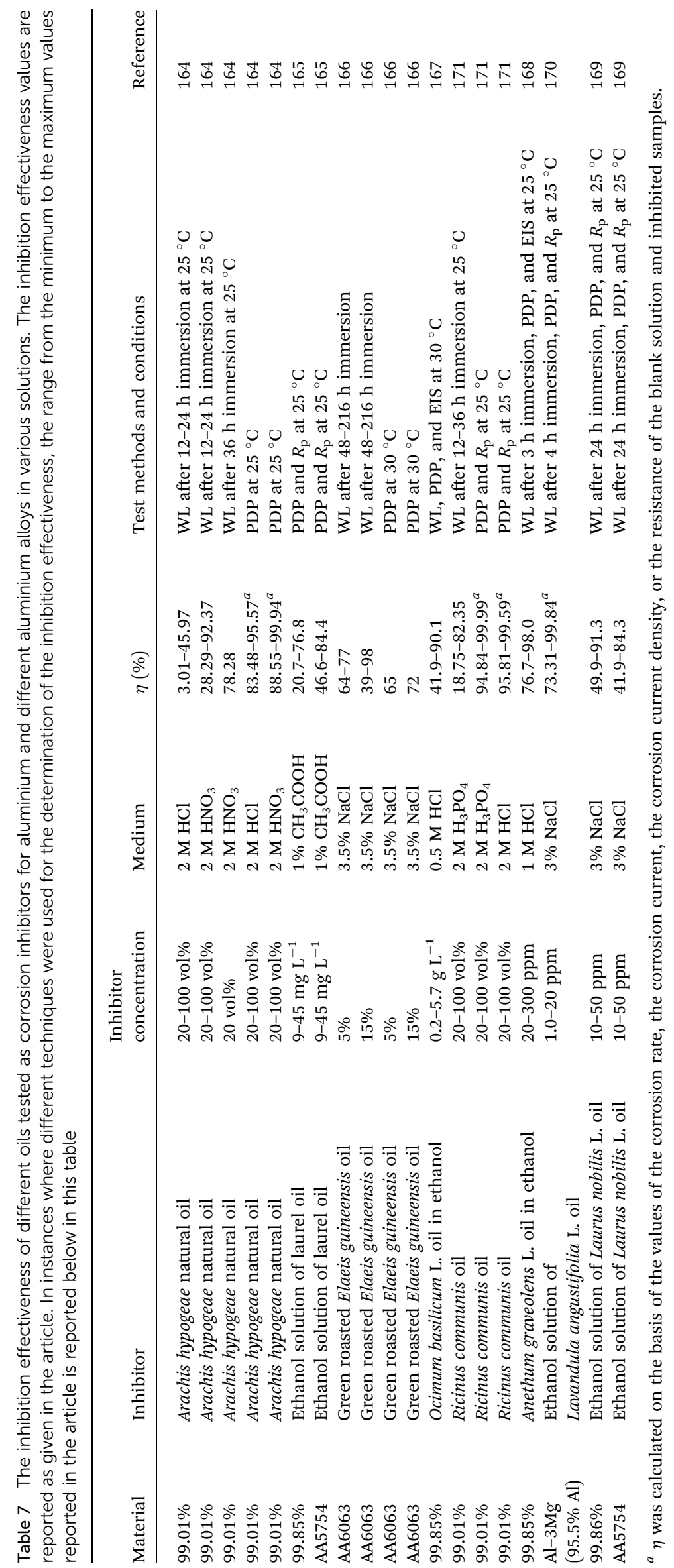


Abdulwahab et al. ${ }^{171}$ The first group of authors investigated the inhibition effectiveness of Arachis hypogeae natural oil as a corrosion inhibitor for $99.01 \%$ aluminium in $2 \mathrm{M} \mathrm{HCl}$ and $2 \mathrm{M}$ $\mathrm{HNO}_{3}$ solutions at $25{ }^{\circ} \mathrm{C} .{ }^{164} \mathrm{~A}$ method for SFE and the identification of volatile flavor components in roasted peanuts (Arachis hypogaea) was described in the review article of Capuzzo et al. ${ }^{62}$ It was reported that the obtained extracts contained compounds such as hexanol, hexanal, methylpyrrole, benzene acetaldehyde, methylpyrazine, 2,6-dimethylpyrazine, ethylpyrazine, 2,3-dimethylpyrazine, 2,3,5-trimethylpyrazine, 2-furancarboxaldehyde, 2-ethyl-5-methyl- and 2-ethyl-6-methylpyrazine, and 3-ethyl-2,5dimethylpyrazine. Popoola et al. ${ }^{\mathbf{1 6 4}}$ reported that Arachis hypogeae natural oil was a better inhibitor in $\mathrm{HNO}_{3}$ than in $\mathrm{HCl}$ solution.

Abdulwahab et al. ${ }^{171}$ tested Ricinus communis oil as a corrosion inhibitor for $99.01 \%$ aluminium alloy in $2 \mathrm{M} \mathrm{HCl}$ and $2 \mathrm{M}$ $\mathrm{H}_{3} \mathrm{PO}_{4}$ at $25{ }^{\circ} \mathrm{C}$. Danlami et al. ${ }^{172}$ reported on Soxhlet extraction of this oil using hexane as a solvent. They reported that the oil contained mainly unsaturated fatty acids (ricinoleic acid) followed by a moderate content of saturated fatty acids (palmitic, stearic, linoleic, linolineic, and dihydroxylstearic acids). In their study, Abdulwahab et al. ${ }^{171}$ reported that there is no significant difference in the performance of the oil (no significant change in the $\eta$ values) in the two acid solutions.

As seen in Table 7, electrochemical techniques, including PDP, $R_{\mathrm{p}}$, and EIS, have been used alongside the classic WL technique to evaluate not only the performance of the oils as corrosion inhibitors, but also to determine their influence on the corrosion reactions. Based on the PDP measurements, the authors concluded that Arachis hypogeae oil ${ }^{164}$ and green roasted Elaeis guineensis oil $^{\mathbf{1 6 6}}$ acted as mixed-type corrosion inhibitors for the respective aluminium materials. Next, Halambek et al. ${ }^{167}$ Halambek and Berkovic, ${ }^{168}$ Halambek et al. ${ }^{169}$ and Halambek et al. ${ }^{\mathbf{1 7 0}}$ reported that Ocimum basilicum L. oil, Anethum graveolens L. oil, Laurus nobilis L. oil, and Lavandula angustifolia L. oil acted as cathodic-type corrosion inhibitors. Finally, Halambek et al. ${ }^{\mathbf{1 6 5}}$ tested the ethanol solution of laurel oil as a corrosion inhibitor for $99.85 \%$ aluminium and AA5754 aluminium alloy in $1 \%$ acetic acid solution at $25{ }^{\circ} \mathrm{C}$. Capuzzo ${ }^{62}$ reported $\mathrm{SC}-\mathrm{CO}_{2}$ extraction as a suitable method for the isolation of volatile and fixed oils from dried berries of $L$. nobilis. The extracts were rich in volatile fraction, which was mainly composed of $(E)$ - $\beta$-ocimene, 1,8-cineole, $\alpha$-pinene, $\beta$-pinene, $\beta$ longipinene, linalyl acetate, $\delta$-cadinene, $\alpha$-terpinyl acetate, and $\alpha$-bulnesene. The authors reported that the ethanol solution of the laurel oil protects (higher inhibition effectiveness) AA5754 aluminium alloy better than $99.85 \%$ aluminium. PDP measurements showed that the ethanol solution of laurel oil acted as an anodic-type inhibitor in the corrosion of $99.85 \%$ aluminium and as a cathodic-type inhibitor in the corrosion of AA5754 aluminium alloy.

Several possible mechanisms were suggested by the authors to explain the inhibition action of the oils tested. Based on the thermodynamic calculations, Halambek et al. ${ }^{165}$ concluded that the ethanol solution of laurel oil adsorbed on the surface through a mixed-type mechanism (both physisorption and chemisorption), which leads to the formation of a protective layer on the aluminium and alloy surface. In addition to this protective layer (film), Halembek et al. ${ }^{\mathbf{1 6 9}}$ suggested that the main component of Laurus nobilis L. oil (1,8-cineole) can adsorb via the lone pair electrons in the oxygen atoms.

The inhibition action of Ocimum basilicum L. oil ${ }^{167}$ was attributed to its main component, linalool. The latter, apart from protonating in acid solution, contains $-\mathrm{OH}$ groups and double bonds in its structure, which are probable adsorption centres. The authors proposed a two-stage mechanism for the inhibition action of the oil. In the first stage, the chloride ions adsorb electrostatically on the positively charged metal surface, giving a negative net charge to the surface. In the second stage, the protonated linalool electrostatically interacted with the negatively charged surface, forming a protective layer on the aluminium surface. Based on the thermodynamic data, the authors suggested that the active components of the oil physisorbed on the aluminium surface. A similar mixed-type mechanism was suggested by Halambek and Berković ${ }^{\mathbf{1 6 8}}$ for the adsorption of Anethum graveolens L. oil on aluminium surface. According to the authors, chemisorption can occur either by displacing the water molecules from the aluminium surface and electron sharing between the oxygen atoms and aluminium or through donor-acceptor bonds between the $\pi$ electrons of the aromatic ring and the p-orbitals of Al. Physisorption can occur between the protonated species and the negatively charged aluminium surface from the chloride ions.

Fayomi and Popoola ${ }^{\mathbf{1 6 6}}$ investigated green roasted Elaeis guineensis oil as a corrosion inhibitor for AA6063 aluminium alloy in $3.5 \% \mathrm{NaCl}$ solution at $30{ }^{\circ} \mathrm{C}$. As shown previously, Elaeis guineensis oil was extracted by $\mathrm{SC}-\mathrm{CO}_{2}$ extraction and it was shown that the main constituents were carotene, vitamin E, sterols, and squalene. ${ }^{173}$ The oil showed good protection $(\eta=$ $68-78 \%$ ) even after $216 \mathrm{~h}$ of immersion. The authors attributed the inhibition action of this oil to the adsorption of the surfaceactive compounds and oxide on the aluminium surface, which modify the wettability and the interface.

\section{Other natural products as corrosion inhibitors}

Apart from the main groups of green inhibitors described above, a few other natural products have been tested as corrosion inhibitors for aluminium materials in alkaline and chloride-containing solutions. The inhibition effectiveness of all the natural products tested was found to increase with increasing concentration of the product. The main findings (as described above) are presented in Table 8.

Rosliza et $a{ }^{174}$ reported on the inhibition effectiveness of natural honey as a corrosion inhibitor for $\mathrm{Al}-\mathrm{Mg}-\mathrm{Si}$ alloy (97.36\% aluminium) in seawater at $25{ }^{\circ} \mathrm{C}$. Gudic et al. ${ }^{175}$ investigated the inhibition effectiveness of five types of honey dissolved in $\mathrm{NaCl}$, i.e. oak honey (H1), coniferous honeydew honey (H2), winter savory honey (H3), alder buckthorn honey (H4), and carob tree honey (H5), as corrosion inhibitors for AA5052 aluminium alloy in $0.5 \mathrm{M} \mathrm{NaCl}$ solution at $20^{\circ} \mathrm{C}$. The inhibition effectiveness followed the order $\mathrm{H} 3<\mathrm{H} 5<\mathrm{H} 4<\mathrm{H} 2<\mathrm{H} 1$. 
Table 8 The inhibition effectiveness of some natural products tested as corrosion inhibitors for aluminium and different aluminium alloys in various solutions. The inhibition effectiveness values are reported as given in the article. In instances where different techniques were used for the determination of the inhibition effectiveness, the range from the minimum to the maximum values reported in the article is reported below in this table

\begin{tabular}{|c|c|c|c|c|c|c|}
\hline Material & Inhibitor & $\begin{array}{l}\text { Inhibitor } \\
\text { concentration }\end{array}$ & Medium & $\eta(\%)$ & $\begin{array}{l}\text { Test methods and } \\
\text { conditions }\end{array}$ & Reference \\
\hline $97.36 \%$ & Natural honey & 200-1000 ppm & Seawater & 63.43-91.85 & PDP, $R_{\mathrm{p}}$, and EIS & 174 \\
\hline AA5052 & Oak honey dissolved in $\mathrm{NaCl}$ & $1000 \mathrm{ppm}$ & $0.5 \mathrm{M} \mathrm{NaCl}$ & $81.52-82.67^{a}$ & PDP, $R_{\mathrm{p}}$, and EIS at $20^{\circ} \mathrm{C}$ & 175 \\
\hline AA5052 & $\begin{array}{l}\text { Coniferous honeydew honey } \\
\text { dissolved in } \mathrm{NaCl}\end{array}$ & $1000 \mathrm{ppm}$ & $0.5 \mathrm{M} \mathrm{NaCl}$ & $77.28-80.59^{a}$ & $\mathrm{PDP}, R_{\mathrm{p}}$, and EIS at $20^{\circ} \mathrm{C}$ & 175 \\
\hline AA5052 & Winter savory honey dissolved in $\mathrm{NaCl}$ & $1000 \mathrm{ppm}$ & $0.5 \mathrm{M} \mathrm{NaCl}$ & $58.88-64.82^{a}$ & $\mathrm{PDP}, R_{\mathrm{p}}$, and EIS at $20^{\circ} \mathrm{C}$ & 175 \\
\hline AA5052 & Alder buckthorn honey dissolved in $\mathrm{NaCl}$ & $1000 \mathrm{ppm}$ & $0.5 \mathrm{M} \mathrm{NaCl}$ & $70.09-72.88^{a}$ & PDP, $R_{\mathrm{p}}$, and EIS at $20^{\circ} \mathrm{C}$ & 175 \\
\hline AA5052 & Carob tree honey dissolved in $\mathrm{NaCl}$ & $1000 \mathrm{ppm}$ & $0.5 \mathrm{M} \mathrm{NaCl}$ & $65.16-69.93^{a}$ & PDP, $R_{\mathrm{p}}$, and EIS at $20^{\circ} \mathrm{C}$ & 175 \\
\hline AA5052 & Oak honey dissolved in $\mathrm{NaCl}$ & $400-1200 \mathrm{ppm}$ & $0.5 \mathrm{M} \mathrm{NaCl}$ & $61.87-85.65$ & PDP and $R_{\mathrm{p}}$ at $20^{\circ} \mathrm{C}$ & 175 \\
\hline AA5052 & $\begin{array}{l}\text { Coniferous honeydew honey } \\
\text { dissolved in } \mathrm{NaCl}\end{array}$ & $400-1200 \mathrm{ppm}$ & $0.5 \mathrm{M} \mathrm{NaCl}$ & $56.72-82.65$ & PDP and $R_{\mathrm{p}}$ at $20^{\circ} \mathrm{C}$ & 175 \\
\hline Pure & Animal glue & $2000 \mathrm{ppm}$ & $0.1 \mathrm{M} \mathrm{NaOH}$ & $43.49-59.05$ & PDP at $30-60{ }^{\circ} \mathrm{C}$ & 176 \\
\hline AA6063 & Animal glue & $2000 \mathrm{ppm}$ & $0.1 \mathrm{M} \mathrm{NaOH}$ & $41.62-54.80$ & PDP at $30-60{ }^{\circ} \mathrm{C}$ & 176 \\
\hline 20556 alloy & Animal glue & $2000 \mathrm{ppm}$ & $0.1 \mathrm{M} \mathrm{NaOH}$ & $30.89-40.29$ & $\mathrm{PDP}$ at $30-60{ }^{\circ} \mathrm{C}$ & 176 \\
\hline Pure & Animal glue & $100-2000 \mathrm{ppm}$ & $0.1 \mathrm{M} \mathrm{NaOH}$ & $10.86-59.05$ & $\mathrm{PDP}, \mathrm{EIS}$, and $\mathrm{CV}$ at $30^{\circ} \mathrm{C}$ & 176 \\
\hline AA6063 & Animal glue & $100-2000 \mathrm{ppm}$ & $0.1 \mathrm{M} \mathrm{NaOH}$ & $8.75-54.80$ & PDP, EIS, and CV at $30^{\circ} \mathrm{C}$ & 176 \\
\hline 20556 alloy & Animal glue & $100-2000 \mathrm{ppm}$ & $0.1 \mathrm{M} \mathrm{NaOH}$ & $4.12-41.52$ & PDP, EIS, and CV at $30^{\circ} \mathrm{C}$ & 176 \\
\hline
\end{tabular}

${ }^{a} \eta$ was calculated on the basis of the values of the corrosion rate, the corrosion current, the corrosion current density, or the resistance of the blank solution and inhibited samples.

PDP measurements performed in both studies showed that all types of honeys acted as mixed-type inhibitors. ${ }^{174,175}$ However, for all the tested honey types Gudić et al. ${ }^{175}$ reported a predominant action on the anodic reaction. The inhibition action of the different honey types was attributed to the formation of a surface layer (a thin film) on the surface of the aluminium materials, which blocked the further attack on aluminium. ${ }^{174,175}$ Based on the thermodynamic calculations, both research groups suggested physisorption as the possible adsorption mechanism for the respective honey types studied. ${ }^{174,175}$

Abdallah et al. ${ }^{176}$ boiled animal connective tissue for a long time and tested the obtained glue as a corrosion inhibitor for aluminium as well as AA6063 and 20556 (92.47\% aluminium) aluminium alloys in $0.1 \mathrm{M} \mathrm{NaOH}$ solution at $30^{\circ} \mathrm{C}$. The inhibition effectiveness decreased with increasing $\mathrm{Si}$ content following the order aluminium $>$ AA6063 alloy $>20556$ alloy. An increase in temperature resulted in a decrease in inhibition effectiveness. The PDP measurements showed that the animal glue acted as a mixed-type inhibitor. The authors suggested that the adsorption of the animal glue is carried out through the substitution of the water molecules on the surface of the aluminium materials.

\section{Outlook}

Green compounds are by far the most attractive area of research on corrosion inhibitors. However, several aspects need to be taken into account before these inhibitors can be used in real industrial applications. The "green" aspect of the studied natural products needs to be evaluated. In order to actually understand what is green and what is not, toxicity, biodegradablility, and bioaccumulation tests would need to be performed. ${ }^{1}$ In most of the reported articles summarised herein, these kinds of tests were not performed and this remains an open subject for future studies. However, there is a high potential that the extracts are non-hazardous as they are extracted from the natural environment. Some of them were also already applied in other different applications, where their non-toxic nature was at least indirectly confirmed. This also applies to the mentioned drugs, as they have all been proven safe clinically and are actually even today used in pharmacotherapy in humans. Of course, the actual dose of exposure/ intake has to be considered; nevertheless, the latter facts cannot be denied. Moreover, as seen herein, the literature concerning drugs as corrosion inhibitors for aluminium and its alloys is scarce yet interesting, and as such could represent an open subject for future studies.

One way of quickly assessing environmental acceptability is to employ the German WGK classification as the data on this classification are readily available by most chemical providers. WGK (German: Wassergefährdungsklassen) stands for the German Water Hazard Class. In accordance with the national German VwVwS regulation (German: Verwaltungsvorschrift wassergefährdende Stoffe), all substances are classified as either non-hazardous to water or assigned to one of three classes, WGK 1 , WGK 2, and WGK 3, with increasing water hazard. The lowest class, WGK 1 , is relatively harmless and close to nonhazardous. ${ }^{8}$

Another way to evaluate toxicity is according to the LC50 or EC50 categories (lethal or effective concentrations in $50 \%$ of the tested subjects, respectively), which rank chemicals from supertoxic to practically non-toxic. Moreover, biodegradability is usually evaluated by the $60 \%$ persistence of the components 
in the environment after 28 days. Furthermore, bioaccumulation is evaluated by the partition coefficient $\mathrm{Po} / \mathrm{w}$ (partition between 1-octanol and water). ${ }^{1}$ The higher this partition coefficient is the higher the possibility for the compound to be bioaccumulated.

Usually, authors do not report the specific components present in the extracts. It would be beneficial if, before testing an extract's corrosion inhibition performance, the separation and analysis of individual components were carried out, e.g. HPLC-MS or GC-MS analysis, to reveal which compounds are responsible for the corrosion inhibition effectiveness of the extract used. The choice of the extraction method is of great importance. Taking into account the variety of problems associated with the high processing temperatures and long processing times in conventional extraction procedures, there is an essential need to promote the development and application of alternative extraction techniques that do not require severe operating conditions including high processing temperatures and harmful organic solvents. Supercritical fluid extraction represents an alternative to the extraction methods summarised in this review, which allows selective isolation of natural compounds from natural materials at moderate temperatures.

Considering the available studies reporting the use of drugs from various pharmacotherapeutic groups as corrosion inhibitors of aluminium, several aspects need to be clarified more thoroughly for this field to be fully acknowledged. From the range of drugs tested as potential corrosion inhibitors for aluminium, antimicrobial drugs (antibacterial and antifungal drugs) have the highest potential. Since there are still many open questions related to the corrosion inhibition mechanism of these compounds, their interaction with aluminium on the molecular level should be studied in more detail. There is also the need to systematically evaluate the influence of other physico-chemical parameters (e.g. temperature, $\mathrm{pH}$, ionic strength, etc.) on the corrosion inhibition effectiveness of these drugs before their application becomes more realistic. In particular, we need to consider the amount used (usually it is high, considering that large metallic surfaces need to be protected against corrosion) and the potential impact on the environment. Additionally, as already pointed out by Gece, ${ }^{22}$ not all drugs are readily biodegradable and their transformation products may be equally or even more hazardous to the environment. Therefore, more studies need to be performed before such corrosion inhibitors can be considered green. However, we are confident that this type of review can significantly aid in finding potential candidates for further (very expensive) tests (e.g. biodegradability, toxicity, and bioaccumulation). ${ }^{1}$ On the other hand, considering the possible application of aluminium and its alloys in medicine (e.g. orthopaedic implants), drugs as corrosion inhibitors seem even more attractive. Therefore, the additional testing necessary to tackle the remaining open questions will be likely performed rather sooner than later.

In the majority of the studies the authors do not report how the natural oils were obtained. One of the most convenient and efficient methods to extract these oils from plant materials at low temperatures is to apply high-pressure extraction with supercritical fluids, hence limiting thermal degradation, and the omission of the use of toxic solvents. $\mathrm{SC}^{-\mathrm{CO}_{2}}$ is overwhelmingly the solvent of choice due to its ability to easily penetrate inside plant material and high solvent power. Nevertheless, SC- $\mathrm{CO}_{2}$ also has important disadvantages, such as it being limited to the processing of dry raw materials and compounds of low polarity and low molecular weight. These limitations could be overcome through the use of co-solvents and alternative supercritical fluids such as propane, argon, and $\mathrm{SF}_{6}$. Water, as the cheapest solvent, represents another alternative solvent or co-solvent with the aim of modifying the polarity of the solvent. Subcritical water extraction has become an increasingly popular alternative technology in the extraction of phenolic compounds. When water is heated well above $100{ }^{\circ} \mathrm{C}$ its dielectric constant decreases and its ionic product increases. That means that the same solvent can be used to extract inorganic and organic components. The main limitation is the extremely high energy required to heat the media. Furthermore, water above its critical point $\left(374{ }^{\circ} \mathrm{C}, 221\right.$ bar) demonstrates a highly corrosive nature, which might be a problem for the high-pressure equipment used to obtain these products.

There is still some room to improve the performance of these green corrosion inhibitors. As described above, the authors only reported the use of corrosion inhibitors, in a few cases with the addition of intensifiers (mainly potassium halides). However, these corrosion inhibitors would be even more effective if actual corrosion inhibition formulations were employed. ${ }^{8}$ Moreover, a more detailed evaluation of the inhibition mechanisms through the use of electrochemical and surface analysis techniques should be considered.

\section{Conclusions}

The research work published over the past two decades on the corrosion inhibition of aluminium and its alloys in different solutions, using a variety of natural compounds (including plant extracts, gums, drugs, and natural oils) was presented in this review article. Plant extracts were by far the most studied natural products. A wide variety of solvents (organic solvents, water, acids, and bases) were used to prepare extracts of mainly the leaves, seeds, and stem of the respective plants. Pure aluminium, $1 \mathrm{xxx}, 3 \mathrm{xxx}, 6 \mathrm{xxx}$, and $7 \mathrm{xxx}$ series aluminium alloys were among the most tested aluminium materials.

The inhibition effectiveness of the green corrosion inhibitors tested increased with increasing concentration. A synergistic effect upon the addition of halides (especially iodide) was reported. The corrosion tests were carried out in a temperature range of 20 to $75{ }^{\circ} \mathrm{C}$. An increase in temperature was usually reflected in the lower inhibition effectiveness of the tested natural products.

Weight loss and hydrogen evolution were the most frequently used techniques to evaluate the corrosion inhibition effectiveness of the studied green inhibitors. A few studies were performed using electrochemical techniques. Based on the polarisation measurements, the majority of the studies reported that these products were found to act as mixed-type inhibitors. Moreover, physisorption was reported as the most probable 
mechanism for the adsorption of these products on the surface of the aluminium materials. Alternatively, the inhibition action of these products was attributed to the formation of a protective layer (film) on the surface of the aluminium materials. According to the authors, adsorption occurred through the adsorption centres present in their active components. However, particular compounds were rarely identified and reported for the natural products tested.

Although a considerable number of studies have been performed, this is still a relatively unexplored field of research with great potential for improvement, especially as regards the methods used to obtain the green corrosion inhibitors and corrosion inhibitor formulation designs.

\section{Abbreviations}

\begin{tabular}{ll} 
EIS & Electrochemical impedance spectroscopy \\
GSP & Galvanostatic polarisation \\
$\mathrm{HE}$ & Hydrogen evolution \\
PDP & Potentiodynamic polarisation \\
PSP & Potentiostatic polarisation \\
$R_{\mathrm{p}}$ & Polarisation of resistance \\
SC-CO & \\
SFE & Supercritical carbon dioxide \\
WL & Supercritical fluid extraction \\
$\eta$ & Weight loss \\
\hline & Inhibition effectiveness
\end{tabular}

\section{Acknowledgements}

The authors would like to acknowledge the financial support for this project received from the Slovenian Research Agency (grant numbers: BI-HR/16-17-045 and P2-0032, and P2-0046).

\section{References}

1 R. M. Palou, O. Olivares-Xomelt and N. V. Likhanova, in Developments in corrosion protection, ed. M. Aliofkhazraei, InTech, 2014, pp. 431-465.

2 H. X. Jiang, L. S. Chen, J. G. Zheng, S. Han, N. Tang and B. R. Smith, Tree Physiol., 2008, 28, 1863-1871.

3 S. V. Verstraeten, L. Aimo and P. I. Oteiza, Arch. Toxicol., 2008, 82, 789-802.

4 A. T. Proudfoot, Clin. Toxicol., 2009, 47, 89-100.

5 J. R. Davis, Corrosion of aluminium and aluminium alloys, ASM International, Ohio, 1999.

6 K. Xhanari and M. Finšgar, RSC Adv., 2016, 6, 62833-62857.

7 K. Xhanari and M. Finšgar, Arabian J. Chem., 2016, DOI: 10.1016/j.arabjc.2016.08.009, in press.

8 M. Finšgar and J. Jackson, Corros. Sci., 2014, 86, 17-41.

9 I. B. Obot and N. O. Obi-Egbedi, Int. J. Electrochem. Sci., 2009, 4, 1277-1288.

10 I. B. Obot, N. O. Obi-Egbedi, S. A. Umoren and E. E. Ebenso, Int. J. Electrochem. Sci., 2010, 5, 994-1007.

11 A. Khadraoui, A. Khelifa, K. Hachama and R. Mehdaoui, J. Mol. Liq., 2016, 214, 293-297.
12 A. S. Fouda, A. A. Al-Sarawy, F. S. Ahmed and H. M. ElAbbasy, Corros. Sci., 2009, 51, 485-492.

13 I. B. Obot and N. O. Obi-Egbedi, E-J. Chem., 2010, 7, 837843.

14 S. A. Umoren and E. E. Ebenso, Pigm. Resin Technol., 2008, 37, 173-182.

15 S. A. Umoren, I. B. Obot, E. E. Ebenso, P. C. Okafor, O. Ogbobe and E. E. Oguzie, Anti-Corros. Methods Mater., 2006, 53, 277-282.

16 A. M. Al-Turkustani, Mod. Appl. Sci., 2010, 4, 105-124.

17 A. M. Abdel-Gaber, E. Khamis, H. Abo-Eldahab and S. Adeel, Mater. Chem. Phys., 2010, 124, 773-779.

18 S. A. Umoren and M. M. Solomon, J. Ind. Eng. Chem., 2015, 21, 81-100.

19 L. Pirvu, A. Armatu, C. Bubueanu, G. Pintilie and S. Nita, Rom. Biotechnol. Lett., 2010, 15, 5683-5689.

20 L. Pirvu, D. Barbulescu, C. Nichita, S. Nita and S. C. Mihul, Rom. Biotechnol. Lett., 2011, 16, 5937-5943.

21 M. Jayalakshmi and V. S. Muralidharan, Corros. Rev., 1997, 15, 315-340.

22 G. Gece, Corros. Sci., 2011, 53, 3873-3898.

23 N. Patni, S. Agarwal and P. Shah, Chinese Journal of Engineering, 2013, 2013, 784186.

24 B. E. A. Rani and B. B. J. Basu, Int. J. Corros., 2012, 2012, 380217.

25 G. Khan, K. M. S. Newaz, W. J. Basirun, H. B. M. Ali, F. L. Faraj and G. M. Khan, Int. J. Electrochem. Sci., 2015, 10, 6120-6134.

26 A. Peter, I. B. Obot and S. K. Sharma, Int. J. Ind. Chem., 2015, 6, 153-164.

27 K. S. Hari, S. Karthikeyan, P. Jeeva and G. Sundaramali, International Journal of Recent Scientific Research, 2012, 3, 61-67.

28 M. Sangeetha, S. Rajendran, J. Sathiyabama and K. Krishnaveni, Port. Electrochim. Acta, 2013, 31, 41-52.

29 J. Buchweishaija, Univ. Sci. J., 2009, 35, 77-92.

30 M. H. Hussin and M. J. Kassim, Mater. Chem. Phys., 2011, 125, 461-468.

31 D. E. Raynie, Anal. Chem., 2006, 78, 3997-4003.

32 M. Skerget, Z. Knez and M. Knez-Hrncic, J. Chem. Eng. Data, 2011, 56, 694-719.

33 G. Brunner, Fett Wiss. Technol., 1986, 88, 464-474.

34 K. Abascal, L. Ganora and E. Yarnell, Phytother. Res., 2005, 19, 655-660.

35 R. Marr and T. Gamse, Chem. Eng. Process., 2000, 39, 19-28.

36 R. P. Metivier, F. J. Francis and F. M. Clydesdale, J. Food Sci., 1980, 45, 1099-1100.

37 S. Guyot, N. Marnet and J. F. Drilleau, J. Agric. Food Chem., 2001, 49, 14-20.

38 B. Labarbe, V. Cheynier, F. Brossaud, J. M. Souquet and M. Moutounet, J. Agric. Food Chem., 1999, 47, 2719-2723.

39 W. B. Wan Nik, F. Zulkifli, R. Rosliza and M. M. Rahman, Int. J. Res. Mod. Eng. Emerg. Tech., 2011, 1, 723-728.

40 S. A. Umoren, U. M. Eduok, A. U. Israel, I. B. Obot and M. M. Solomon, Green Chem. Lett. Rev., 2012, 5, 303-313.

41 K. Shalabi, A. S. Fouda, G. Y. Elewady and A. El-Askalany, Prot. Met. Phys. Chem. Surf., 2014, 50, 420-431. 
42 A. Singh, Y. Lin, W. Liu, S. Yu, J. Pan, C. Ren and D. Kuanhai, J. Ind. Eng. Chem., 2014, 20, 4276-4285.

43 M. A. Deyab, J. Taiwan Inst. Chem. Eng., 2016, 58, 536-541. 44 N. J. N. Nnaji, N. O. Obi-Egbedi and C. O. B. Okoye, Port. Electrochim. Acta, 2014, 32, 157-182.

45 C. A. Loto and A. P. I. Popoola, Can. J. Pure Appl. Sci., 2012, 6, 1973-1980.

46 P. Arora, S. Kumar, M. K. Sharma and S. P. Mathur, E-J. Chem., 2007, 4, 450-456.

47 X. Li and S. Deng, Corros. Sci., 2012, 65, 299-308.

48 R. Chauhan, U. Garg and R. K. Tak, E-J. Chem., 2011, 8, 8590.

49 T. Jain, R. Chowdhary and S. P. Mathur, Mater. Corros., 2006, 57, 422-426.

50 S. Deng and X. Li, Corros. Sci., 2012, 64, 253-262.

51 E. I. Ating, S. A. Umoren, I. I. Udousoro, E. E. Ebenso and A. P. Udoh, Green Chem. Lett. Rev., 2010, 3, 61-68.

52 A. I. Onen, J. T. Barminas and J. Jacob, Chem. Sci. Trans., 2013, 2, 1326-1333.

53 P. M. Ejikeme, S. G. Umana and O. D. Onukwuli, Port. Electrochim. Acta, 2012, 30, 317-328.

54 S. Kumar and S. P. Mathur, ISRN Corros., 2013, 2013, 476170.

55 G. S. Yiase, S. O. Adejo, T. G. Tyohemba, U. J. Ahile and J. A. Gbertyo, International Journal of Advanced Research in Chemical Science, 2014, 1, 38-46.

56 M. Ramirez-Arteaga, M. G. Valladares and J. G. G. Rodriguez, Int. J. Electrochem. Sci., 2013, 8, 68646877.

57 L. Divya, S. Nisha, T. Suresh, L. Mohsin and J. Prakash, Pigm. Resin Technol., 2016, 45, 106-118.

58 I. C. Madufor, U. E. Itodoh, M. U. Obidiegwu and M. S. Nwakaudu, IOSR Journal of Engineering, 2012, 2, 16-23.

59 R. A. Ukpe, S. A. Odoemelam, A. O. Odiongenyi and N. O. Eddy, J. Bioprocess. Chem. Eng., 2014, 2(2), DOI: 10.15297/JBCE.V2I2.03.

60 A. Rajendran and C. Karthikeyan, International Journal of Plant Research, 2012, 2, 9-14.

61 A. S. Fouda, H. S. Gadow and K. Shalabi, Int. J. Res. Rev. Appl. Sci., 2015, 23, 28-45.

62 A. Capuzzo, M. E. Maffei and A. Occhipinti, Molecules, 2013, 18, 7194-7238.

63 K. M. Emran, N. M. Ahmed, B. A. Torjoman, A. A. Al-Ahmadi and S. N. Sheekh, J. Mater. Environ. Sci., 2014, 5, 1940-1950.

64 N. Chaubey, V. K. Singh, Savita, M. A. Quraishi and E. E. Ebenso, Int. J. Electrochem. Sci., 2015, 10, 504-518.

65 A. Sirajunnisa, M. I. F. Mohamed, A. Subramania and B. R. Venkatraman, International Journal of Science Engineering and Advance Technology, 2014, 2, 58-71.

66 A. Singh, E. E. Ebenso and M. A. Quraishi, Int. J. Electrochem. Sci., 2012, 7, 3409-3419.

67 S. Geetha, S. Lakshmi and K. Bharathi, J. Chem. Pharm. Res., 2013, 5, 195-204.

68 S. Geetha, S. Lakshmi and K. Bharathi, International Journal of Advanced Scientific and Technical Research, 2013, 3, 258268.
69 S. A. Umoren, I. B. Obot, L. E. Akpabio and S. E. Etuk, Pigm. Resin Technol., 2008, 37, 98-105.

70 A. Singh and M. A. Quraishi, Res. J. Recent Sci., 2012, 1, 5761.

71 S. Rajendran, J. Jeyasundari, P. Usha, J. A. Selvi, B. Narayanasamy, A. P. P. Regis and P. Rengan, Port. Electrochim. Acta, 2009, 27, 153-164.

72 K. L. Prabha, S. Rajam and A. Subramania, J. Chem. Pharm. Res., 2012, 4, 337-347.

73 A. Singh, I. Ahamad and M. A. Quraishi, Arabian J. Chem., 2016, 9, S1584-S1589.

74 T. Y. Soror, Eur. Chem. Bull., 2013, 2, 191-196.

75 A. M. Al-Haj-Ali, N. A. Jarrah, N. D. Mu'azu and R. O. Rihan, J. Appl. Sci. Environ. Manage., 2014, 18, 543-551.

76 D. Prabhu and P. Rao, Int. J. Corros., 2013, 2013, 11.

77 H. A. Fetouh, T. M. Abdel-Fattah and M. S. El-Tantawy, Int. J. Electrochem. Sci., 2014, 9, 1565-1582.

78 H. Gerengi, Ind. Eng. Chem. Res., 2012, 51, 12835-12843.

79 B. A. Abd-El-Nabey, A. M. Abdel-Gaber, G. Y. Elawady and S. El-Housseiny, Int. J. Electrochem. Sci., 2012, 7, 7823-7839.

80 A. M. Al-Turkustani and K. M. Emran, International Journal of Innovative Research in Science, Engineering and Technology, 2015, 4, 1018-1027.

81 S. A. Umoren, I. B. Obot, L. E. Akpabio and S. E. Etuk, Pigm. Resin Technol., 2008, 37, 98-105.

82 K. Berković, S. Kovač and J. Vorkapić-Furač, Acta Aliment., 2004, 33, 237-247.

83 O. K. Abiola, J. O. E. Otaigbe and O. J. Kio, Corros. Sci., 2009, 51, 1879-1881.

84 O. K. Abiola and J. O. E. Otaigbe, Corros. Sci., 2009, 51, 2790-2793.

85 E. E. Oguzie, G. N. Onuoha and E. N. Ejike, Pigm. Resin Technol., 2007, 36, 44-49.

86 O. F. Nwosu and E. Osarolube, Phys. Rev. Res. Int., 2014, 4, 1235-1243.

87 L. A. Nnanna, I. U. Anozie, C. S. Akoma, I. M. Mejeha, K. B. Okeoma and K. I. Mejeh, Am. J. Mater. Sci., 2011, 1, 76-80.

88 L. A. Nnanna, W. O. John and N. Onyinyechi, International Journal of Engineering Research and Reviews, 2014, 2, 113118.

89 A. Sirajunnisa, M. I. Fazal Mohamed, A. Subramania and B. R. Venkatraman, European Journal of Applied Sciences and Technology, 2014, 1, 23-31.

90 N. Chaubey, V. Singh and M. A. Quraishi, Int. J. Ind. Chem., 2015, 6, 317-328.

91 T. T. Bataineh, M. A. Al-Qudah, E. Nawafleh and A. M. Ajlouni, Jordan J. Chem., 2013, 8, 169-178.

92 M. K. Irshedat, E. M. Nawafleh, T. T. Bataineh, R. Muhaidat, M. A. Al-Qudah and A. A. Alomary, Port. Electrochim. Acta, 2013, 31, 1-10.

93 L. A. Nnanna, I. U. Anozie, A. G. I. Avoaja, C. S. Akoma and E. P. Eti, Afr. J. Pure Appl. Chem., 2011, 5, 265-271.

94 I. B. Obot and N. O. Obi-Egbedi, Port. Electrochim. Acta, 2009, 27, 517-524. 
95 T. T. Bataineh, M. A. Al-Qudah, E. M. Nawafleh and N. A. F. Al-Rawashdeh, Int. J. Electrochem. Sci., 2014, 9, 3543-3557.

96 N. Chaubey, Savita, V. K. Singh and M. A. Quraishi, J. Assoc. Arab Univ. Basic Appl. Sci., 2016, 22, 38-44.

97 I. M. Mejeha, A. A. Uroh, K. B. Okeoma and G. A. Alozie, Afr. J. Pure Appl. Chem., 2010, 4, 158-165.

98 L. A. Nnanna, O. C. Nwadiuko, N. D. Ekekwe, C. F. Ukpabi, S. C. Udensi, K. B. Okeoma, B. N. Onwuagba and I. M. Mejeha, Am. J. Mater. Sci., 2011, 1, 143-148.

99 A. K. Oluseyi, A. C. Oluwatoyin, A. A. Abimbola, F. Ayorinde, E.-O. Abiola and J. O. Moriamo, Chem. J., 2012, 2, 153-157.

100 L. A. Nnanna and I. O. Owate, Scientia Africana, 2014, 13, 52-63.

101 O. A. Omotosho and O. O. Ajayi, ITB J. Eng. Sci., 2012, 44, 77-92.

102 A. Khadraoui, A. Khelifa, L. Touafri, H. Hamitouche and R. Mehdaoui, J. Mater. Environ. Sci., 2013, 4, 663-670.

103 I. B. Obot and N. O. Obi-Egbedi, J. Appl. Electrochem., 2010, 40, 1977-1984.

104 I. M. Mejeha, M. C. Nwandu, K. B. Okeoma, L. A. Nnanna, M. A. Chidiebere, F. C. Eze and E. E. Oguzie, J. Mater. Sci., 2012, 47, 2559-2572.

105 L. B. Molina-Ocampo, M. G. Valladares-Cisneros and J. G. Gonzalez-Rodriguez, Int. J. Electrochem. Sci., 2015, 10, 388-403.

106 C. A. Loto, O. O. Joseph and R. T. Loto, Int. J. Electrochem. Sci., 2014, 9, 3637-3649.

107 C. A. Loto, O. O. Joseph, R. T. Loto and A. P. I. Popoola, Int. J. Electrochem. Sci., 2014, 9, 1221-1231.

108 M. K. Pyo, S. H. Choi, S. H. Hwang, T. J. Shin, B. H. Lee, S. M. Lee, Y. H. Lim, D. H. Kim and S. Y. Nah, J. Ginseng Res., 2011, 35, 92-103.

109 N. Aghel, Y. Yamini, A. Hadjiakhoondi and S. M. Pourmortazavi, Talanta, 2004, 62, 407-411.

110 N. Pellegrini, B. Colombi, S. Salvatore, O. V. Brenna, G. Galaverna, D. Del Rio, M. Bianchi, R. N. Bennett and F. Brighenti, J. Sci. Food Agric., 2007, 87, 103-111.

111 T. M. Rababah, F. Banat, A. Rababah, K. Ereifej and W. Yang, J. Food Sci., 2010, 75, C626-C632.

112 I. J. Alinnor and P. M. Ejikeme, Am. Chem. Sci. J., 2012, 2, 122-135.

113 O. K. Abiola, N. C. Oforka, E. E. Ebenso and N. M. Nwinuka, Anti-Corros. Methods Mater., 2007, 54, 219-224.

114 M. Akin, S. Nalbantoglu, O. Cuhadar, D. Uzun and N. Saki, Res. Chem. Intermed., 2015, 41, 899-912.

115 A. O. James and O. Akaranta, International Journal of Applied Chemical Sciences Research, 2014, 2, 1-10.

116 K. J. Orie and M. Christian, International Research Journal of Engineering and Technology, 2015, 2, 1-9.

117 S. R. Al-Mhyawi, Orient. J. Chem., 2014, 30, 541-552.

118 M. Abdallah and B. A. Al Jahdaly, Int. J. Electrochem. Sci., 2015, 10, 9808-9823.

119 I. B. Obot, N. O. Obi-Egbedi and S. A. Umoren, Corros. Sci., 2009, 51, 1868-1875.

120 I. B. Obot and N. O. Obi-Egbedi, Colloids Surf., A, 2008, 330, 207-212.
121 I. B. Obot, N. O. Obi-Egbedi, S. A. Umoren and E. E. Ebenso, Chem. Eng. Commun., 2011, 198, 711-725.

122 I. B. Obot, N. O. Obi-Egbedi and S. A. Umoren, Int. J. Electrochem. Sci., 2009, 4, 863-877.

123 J. I. Bhat and V. D. P. Alva, Synth. React. Inorg., Met.-Org., Nano-Met. Chem., 2012, 42, 951-957.

124 J. Ishwara Bhat and V. P. Alva, Trans. Indian Inst. Met., 2011, 64, 377-384.

125 M. Abdallah, I. Zaafarany, S. O. Al-Karanee and A. A. Abd ElFattah, Arabian J. Chem., 2012, 5, 225-234.

126 S. Leekha, C. L. Terrell and R. S. Edson, Mayo Clin. Proc., 2011, 86, 156-167.

127 M. D. Meti, K. S. Byadagi, S. T. Nandibewoor and S. A. Chimatadar, J. Photochem. Photobiol., B, 2014, 138, 324-330.

128 M. S. Refat, H. M. Al-Maydama, F. M. Al-Azab, R. R. Amin and Y. M. Jamil, Spectrochim. Acta, Part A, 2014, 128, 427446.

129 G. W. Karpin, J. S. Merola and J. O. Falkinham 3rd, Antimicrob. Agents Chemother., 2013, 57, 3434-3436.

130 J. Fei, G. D. Liu, H. J. Yu, Y. G. Zhou and Y. Wang, Orthopedics, 2011, 34, 172.

131 K. Brown, Pharmaceutical historian, 2004, 34, 37-43.

132 D. Waller and A. P. Sampson, Medical pharmacology and therapeutics, Saunders/Elsevier, Edinburgh, 4th edn, 2014.

133 M. Abdallah, Corros. Sci., 2004, 46, 1981-1996.

134 K. A. Caprile, J. Vet. Pharmacol. Ther., 1988, 11, 1-32.

135 D. W. Spelman, M. McDonald and W. J. Spicer, Med. J. Aust., 1989, 151, 346-349.

136 R. M. Fallon and J. E. Girotto, J. Pediatr. Pharmacol. Ther., 2008, 13, 124-140.

137 D. I. Zonios and J. E. Bennett, Semin. Respir. Crit. Care Med., 2008, 29, 198-210.

138 D. Allen, D. Wilson, R. Drew and J. Perfect, Expert Rev. AntiInfect. Ther., 2015, 13, 787-798.

139 M. M. Antonijević and M. B. Petrović, Int. J. Electrochem. Sci., 2008, 3, 1-28.

140 M. Finšgar and I. Milošev, Corros. Sci., 2010, 52, 2737-2749.

141 M. Finšgar, B. Petovar, K. Xhanari and U. Maver, Corros. Sci., 2016, 111, 370-381.

142 S. Goswami and S. Naik, Journal of Scientific and Innovative Research, 2014, 3, 112-121.

143 V. D. Prajapati, G. K. Jani, N. G. Moradiya and N. P. Randeria, Carbohydr. Polym., 2013, 92, 1685-1699.

144 A. S. Deshmukh and T. M. Aminabhavi, in Polysaccharides: Bioactivity and Biotechnology, ed. G. K. Ramawat and J.-M. Mérillon, Springer International Publishing, Cham, 2014, pp. 1-30.

145 V. A. Vaclavik and E. W. Christian, Essentials offood science, Springer Science+Business Media LLC, New York, 3rd edn, 2008.

$146 \mathrm{H}$. Panda, The complete book on gums and stabilizers for food industry, Asia Pacific Business Press Inc., 2010.

147 I. O. Arukalam, N. T. Ijomah, S. C. Nwanonenyi, H. C. Obasi, B. C. Aharanwa and P. I. Anyanwu, Int. J. Sci. Eng. Res., 2014, 5, 663-673. 
148 S. A. Umoren, I. B. Obot, E. E. Ebenso and P. C. Okafor, Port. Electrochim. Acta, 2008, 26, 267-282.

149 P. Ameh and N. Eddy, Res. Chem. Intermed., 2014, 40, 26412649.

150 N. O. Eddy, P. O. Ameh and O. O. Anduang, Port. Electrochim. Acta, 2014, 32, 183-197.

151 P. O. Ameh, Int. J. Phys. Sci., 2014, 9, 184-198.

152 N. O. Eddy, P. O. Ameh, M. Y. Gwarzo, I. J. Okopand and S. N. Dodo, Port. Electrochim. Acta, 2013, 31, 79-93.

153 N. O. Eddy, P. O. Ameh, O. O. Anduang and V. Emaikwu, Int. J. Chem. Mater. Environ. Res, 2014, 1, 3-15.

154 S. A. Umoren, I. B. Obot, E. E. Ebenso and N. Obi-Egbedi, Port. Electrochim. Acta, 2008, 26, 199-209.

155 S. A. Umoren, Port. Electrochim. Acta, 2009, 27, 565-577.

156 S. A. Umoren, Cellulose, 2008, 15, 751-761.

157 N. O. Eddy, U. J. Ibok, P. O. Ameh, N. O. Alobi and M. M. Sambo, Chem. Eng. Commun., 2014, 201, 1360-1383.

158 U. J. Ekpe, E. E. Ebenso and B. S. Antia, West Afr. J. Biol. Appl. Chem., 1996, 41, 16-20.

159 N. O. Eddy, A. O. Odiongenyi, P. O. Ameh and E. E. Ebenso, Int. J. Electrochem. Sci., 2012, 7, 7425-7439.

160 M. A. Dar, Ind. Lubr. Tribol., 2011, 63, 227-233.

161 M. Abdallah, I. Zaafarany, K. S. Khairou and Y. Emad, Chem. Technol. Fuels Oils, 2012, 48, 234-245.

162 M. Abdallah, I. A. Zaafarany, S. Abd El Wanees and R. Assi, Int. J. Electrochem. Sci., 2014, 9, 1071-1086.

163 S. Houbairi, M. Essahli and A. Lamiri, Port. Electrochim. Acta, 2013, 31, 221-233.
164 A. P. I. Popoola, O. S. I. Fayomi and M. Abdulwahab, Int. J. Electrochem. Sci., 2012, 7, 5817-5827.

165 J. Halambek, M. C. Bubalo, I. R. Redovniković and K. Berković, Int. J. Electrochem. Sci., 2014, 9, 5496-5506.

166 O. S. I. Fayomi and A. P. I. Popoola, Silicon, 2014, 6, 137143.

167 J. Halambek, A. Žutinić and K. Berković, Int. J. Electrochem. Sci., 2013, 8, 11201-11214.

168 J. Halambek and K. Berković, Int. J. Electrochem. Sci., 2012, 7, 8356-8368.

169 J. Halambek, K. Berković and J. Vorkapić-Furač, Mater. Chem. Phys., 2013, 137, 788-795.

170 J. Halambek, K. Berković and J. Vorkapić-Furač, Corros. Sci., 2010, 52, 3978-3983.

171 M. Abdulwahab, A. P. I. Popola and O. S. I. Fayomi, Int. J. Electrochem. Sci., 2012, 7, 11706-11717.

172 J. M. Danlami, M. A. A. Zaini, A. Arsad and M. A. C. Yunus, J. Taiwan Inst. Chem. Eng., 2015, 53, 32-39.

173 H. L. N. Lau, Y. M. Choo, A. N. Ma and C. H. Chuah, J. Food Eng., 2008, 84, 289-296.

174 R. Rosliza, W. B. Wan Nik, S. Izman and Y. Prawoto, Curr. Appl. Phys., 2010, 10, 923-929.

175 S. Gudić, L. Vrsalović, M. Kliškić, I. Jerković, A. Radonić and M. Zekić, Int. J. Electrochem. Sci., 2016, 11, 998-1011.

176 M. Abdallah, E. M. Kamar, S. Eid and A. Y. El-Etre, J. Mol. Liq., 2016, 220, 755-761. 